\title{
Exploratory study on high-performance concrete for bridge decks in West Virginia
}

Wenbo Zhang

West Virginia University

Follow this and additional works at: https://researchrepository.wvu.edu/etd

\section{Recommended Citation}

Zhang, Wenbo, "Exploratory study on high-performance concrete for bridge decks in West Virginia" (2001). Graduate Theses, Dissertations, and Problem Reports. 1169.

https://researchrepository.wvu.edu/etd/1169

This Thesis is protected by copyright and/or related rights. It has been brought to you by the The Research Repository @ WVU with permission from the rights-holder(s). You are free to use this Thesis in any way that is permitted by the copyright and related rights legislation that applies to your use. For other uses you must obtain permission from the rights-holder(s) directly, unless additional rights are indicated by a Creative Commons license in the record and/ or on the work itself. This Thesis has been accepted for inclusion in WVU Graduate Theses, Dissertations, and Problem Reports collection by an authorized administrator of The Research Repository @ WVU. For more information, please contact researchrepository@mail.wvu.edu. 


\title{
Exploratory Study on High Performance Concrete For Bridge Decks in West Virginia
}

\author{
Wenbo Zhang
}

Thesis

submitted to the

College of Engineering and Mineral Resources

at West Virginia University in partial fulfillment of the requirements

for the degree of

\author{
Master of Science \\ in \\ Civil Engineering
}

\author{
Julio F. Davalos, Ph.D., Chair \\ Indrajit Ray, PhD., Co-Chair \\ Karl E. Barth, Ph.D. \\ Department of Civil and Environmental Engineering \\ Morgantown, West Virginia \\ 2001
}

Keyword: high performance concrete, experimental studies, compressive strength, permeability, shrinkage, durability 


\title{
Abstract \\ Exploratory Study on High Performance Concrete For Bridge Decks in West Virginia
}

\author{
Wenbo Zhang
}

This study is intended to provide guidelines for a future global effort on the development of HPC mixes in West Virginia using several types of available aggregates. The objective of the present study is to explore the performance of two types of mixtures using fly ash and slag, respectively, and the same limestone coarse aggregate, natural sand, and constant water/cementitious ratio. For each type, three mixtures were evaluated, with one of the three being defined according to the WVDOT-DOH specifications as a reference (20\% fly ash and $30 \%$ slag by weight of total cementitious material), from which we varied the quantity of fly ash or slag by $\pm 5 \%$ to defined the remaining two. Both fresh and hardened concrete properties were evaluated, and the parameters of interest were compressive strength, drying shrinkage, freeze-thaw durability and chloride permeability, which were not affected much by using higher fly ash or slag content. However, when using higher quantity of slag (35\%), the chloride permeability was reduced by nearly $20 \%$. Thus, in future studies, the mixture designs with higher slag and even fly ash content may provide better performance. The best mixture for each type will serve as a foundation for the future optimizations of HPC mix designs in $\mathrm{WV}$. 


\section{ACKNOWLEDGEMENT}

I would like to dedicate this work to my son Daniel and my husband Liyun whose love and whole-hearted support helped me to bring this work and my degree to completion. I would also like to give thanks to my father, mother and sister for encouraging me in pursuing my education. I love you all.

I would like to take this opportunity to express my gratitude to Dr. Julio F. Davalos, an excellent teacher and advisor, for giving me the opportunity to work on this interesting project, and for providing me with the guidance, support and resource necessary for accomplishing my research objectives.

My sincere appreciation also goes to Dr. Indrajit Ray, who served as a co-chair on my committee, for his tremendous support in doing this research, whose wise advice and valuable suggestions helped significantly improve the quality of my work. I would like to thank Dr. Karl E. Barth who served as member of my committee, and whose kindness helped me to overcome difficult circumstances during this study. Also I would like to thank Jennifer Morris, Vivian Luo, David Boyajian, and Haiyong Wu for their friendship and great help in doing lab-testing work.

I would like to acknowledge the financial support received from the West Virginia Department of Transportation, Division of Highways (WVDOT-DOH). This study is part of the WVDOH Research Project \# 165. I would also like to acknowledge the support received from Arrow Concrete Company, and Master Builders Company, who provided all of the raw materials for this project. 


\section{Table of Contents}

$\begin{array}{ll}\text { Abstract } & \text { ii }\end{array}$

Acknowledgement iii

Table of Contents iv

List of Figures vii

List of Tables $\quad$ ix

Chapter 1 Introduction 1

1.1 Research Background 1

1.2 Research Objective and Tasks 3

1.3 Research Plan 3

1.4 Thesis Organization 4

Chapter 2 Literature Review 5

2.1 Definition of HPC for Highway Structures 5

2.2 Research on High Performance Concrete Mixtures 9

2.3 High Performance Concrete Bridge Decks in Four Lead States 15

$2.4 \quad$ HPC Bridge Decks in Other States 16

2.4.1 Florida HPC Experience 17

2.4.2 New York State HPC Experience 17

2.4.3 Montana State HPC Experience 18

2.5 West Virginia Division of Highways HPC Specifications 19

$\begin{array}{lll}2.5 .1 & \text { Materials } & 20\end{array}$

2.5.2 Proportioning 20

$\begin{array}{lll}2.5 .3 & \text { Testing } & 21\end{array}$

2.6 Significance of Current Research 21 
Chapter 3 Experimental Program 22

3.1 Materials 22

3.1.1 Portland Cement 23

3.1.2 Coarse Aggregate 23

3.1.3 Fine Aggregate 25

3.1.4 Fly Ash 26

3.1.5 Slag 26

3.1.6 Silica Fume 27

3.1.7 Chemical Admixtures 29

3.1.8 Mixing Water 29

3.2 Mixture Proportions 29

3.3 Mixing Procedure 32

3.4 Preparations of Test Specimens 33

3.4.1 Cylinder Specimens for Compressive Strength 33

3.4.2 Beam Specimens for Length Change Measurement 34

3.4.3 Beam Specimens for Freeze/Thaw Durability Test 35

3.4.4 Disk Specimen for Rapid Chloride Permeability Test 36

3.4.5 Curing of Different Types of Test Specimens 37

3.5 Testing Procedures 38

3.5.1 Testing on Fresh Concrete 38

3.5.1.1 Slump Test 38

3.5.1.2 Air Content 39

3.5.1.3 Unit Weight 39

3.5.1.4 Temperature 39

3.5.2 Testing of Hardened Concrete 40

3.5.2.1 Compressive Strength $\quad 40$

3.5.2.2 Length Change Measurement (Shrinkage) Test 41

3.5.2.3 Freeze/Thaw Durability Test 42

3.5.2.4 Rapid Chloride Permeability Test 45

Chapter 4 Test Results and Discussions 48

4.1 Fresh Concrete Properties 48 
4.2 Compressive Strength 51

4.3 Length Change Measurement (Shrinkage) 59

4.4 Rapid Freeze/Thaw Test 66

$\begin{array}{lll}4.5 & \text { Rapid Chloride Permeability Test }\end{array}$

Chapter 5 Summary and Conclusions $\quad \mathbf{7 4}$

$\begin{array}{lll}5.1 & \text { Summary of Results } & 74\end{array}$

$\begin{array}{lll}5.2 \text { Conclusions } & 76\end{array}$

Bibliography

$\begin{array}{lll}\text { Appendix A } & \text { Compressive Strength Test Results } & 84\end{array}$

$\begin{array}{lll}\text { Appendix B } & \text { Shrinkage Test Results } & 86\end{array}$

$\begin{array}{lll}\text { Appendix C Rapid Freeze/Thaw Test Results } & 88\end{array}$

Appendix D 42-Day RCPT Test Results $\quad 90$ 


\section{List of Figures}

Figure 3.1 Graded Limestone of $3 / 4$ inch Size 24

Figure 3.2 Typical River Sand 26

Figure 3.3 Class F Fly Ash 27

$\begin{array}{lll}\text { Figure } 3.4 & \text { Slag } & 28\end{array}$

Figure 3.5 Silica Fume 28

Figure 3.6 Drum Mixer of 3-cubic Feet Capacity 33

Figure 3.7 Compressive Strength Test Specimen 34

Figure 3.8 Shrinkage Beam Specimen 35

Figure 3.9 Freeze-Thaw Beam Specimen 36

Figure 3.10 Rapid Chloride Permeability Test Specimen 37

Figure 3.11 Metal Cone to Measure Slump 38

Figure 3.12 Apparatus Used to Measure the Air Content in the Concrete 39

Figure 3.13 Compressive Strength Test Machine 40

Figure 3.14 Specimen After Shear Failure 41

Figure 3.15 Length Change Measurement in Progress 42

Figure 3.16 Freeze/Thaw Testing Chamber with Specimens 43

Figure 3.17a Sonometer (Resonance Frequency Test Apparatus) 44

Figure 3.17b Fundamental Transverse Frequency Test in Progress 44

Figure 3.18a Vacuum System and Charge-Passed Measurement Apparatus 46

Figure 3.18b Chloride Permeability Test in Progress 46

Figure 3.18c Close View of Chloride Permeability Test 47

Figure 4.1 Compressive Strength - Age Relationship of Group F HPC 54

Figure 4.2 Compressive Strength - Age Relationship of Group S HPC 54

Figure 4.3 28-day Compressive Strength of Group F HPC Mixtures 55

Figure 4.4 28-day Compressive Strength of Group S HPC Mixtures 55

Figure 4.5 56-day Strengths of Group F Mixtures 56

Figure 4.6 56-day Strengths of Group S Mixtures 56 
Figure 4.7 Drying Shrinkage of Group F HPC at Different Ages 61

Figure 4.8 Drying Shrinkage of Group S HPC at Different Ages 62

Figure 4.9 Drying Shrinkage of Group F HPC at 14 Days of Drying 62

Figure 4.10 Drying Shrinkage of Group S HPC at 14 Days of Drying 63

Figure 4.11 Drying Shrinkage of Group F HPC at 28 Days of Drying 63

Figure 4.12 Drying Shrinkage of Group S HPC at 28-Day of Drying 64

Figure 4.13 Charges-Passed in RCPT Test of Mixtures in Group F 71

Figure 4.14 Charge-Passed in RCPT Test of Mixtures in Group S 71

Figure 4.15 Comparison of Chloride Permeability Among Mixtures 72 


\section{List of Tables}

Table 2.1 Definition of HPC for Highway Bridge 7

Table 2.2 Benefits of Using HPC in Highway Bridge Construction 7

Table 2.3 FHWA HPC Performance Grades in SI Units 8

Table 2.4 FHWA HPC Performance Grades in US Customary Units 8

Table 2.5 Mixture Proportions per Cubic Yard of Concrete 11

Table 2.6 Four Lead States Mixture Proportions 16

Table 2.7 Compressive Strength and Rapid Chloride Permeability Results of Lead States 16

Table 2.8 Mixture Proportions in Montana State 19

Table 2.9 WVDOH Specifications of HPC 20

Table 3.1 Material Composition of Type I Portland Cement 23

Table 3.2 Properties of Coarse Aggregate (Limestone) 24

Table 3.3 Sieve Analyses of Coarse Aggregate 24

Table 3.4 Properties of Fine Aggregate 25

Table 3.5 Sieve Analysis of Fine Aggregate 25

Table 3.6a Mixture Proportion of Group F in US Customary Units 31

Table 3.6b Mixture Proportion of Group F in SI Units 31

Table 3.7a Mixture Proportion of Group S in US Customary Units 31

Table 3.7b Mixture Proportion of Group S in SI Units 31

Table 4.1 Mixture Proportioning of HPC of Fly Ash Group (Group F) 49

Table 4.2 Mixture Proportioning of HPC of Slag Group (Group S) 49

Table 4.3 Characteristics of Freshly Mixed HPC of Fly Ash Group (Group F) 49

Table 4.4 Characteristics of Freshly Mixed HPC of Slag Group (Group S) 50

Table 4.5 Compressive Strength of Group F HPC at Different Ages 52

Table 4.6 Compressive Strength of Group S HPC at Different Ages 52

Table 4.7 Coefficients for Compressive Strength Models of Different Mixtures 
Table 4.8 Drying Shrinkage of Group F HPC at Different Ages 60

Table 4.9 Drying Shrinkage of Group S HPC at Different Ages 60

Table 4.10 Coefficients for Shrinkage Models of Different Mixtures 61

Table 4.11 Dynamic Modulus of Mixtures in Group F 67

Table 4.12 Dynamic Modulus of Mixtures in Group S 68

Table 4.13 Durability Factor of Group F and Group S HPC 68

Table 4.14 Charge-passed (Coulombs) in RCPT for Group F HPC 70

Table 4.15 Charge passed (Coulombs) in RCPT for Group S HPC 70

Table 5.1 Grades for Different Characteristics of All Mixtures $\quad 77$ 


\section{Chapter 1}

\section{Introduction}

\subsection{Research Background}

Concrete is used in several types of structures including buildings, highways, bridges, and many others. It is estimated that more than 500 million tons of concrete is produced in the United States every year and several times this volume worldwide [Silver Spring].

Although concrete structures are thought of as being permanent, they are apparently not problem-free. Currently in the United States, about 33\% of highway bridges are rated substandard [Better Roads Magazine, 1993] with major problems associated to concrete deterioration. Many concrete pavements and bridge decks failed before reaching their expected design life.

An estimate made in 1985 showed that over $\$ 400$ billion would be needed by the end of the $20^{\text {th }}$ century for repair and rehabilitation of the nation's highways and bridges in the United Sates [Special Report202, 1987]. Another estimate made in 1987 indicated that between one and three trillion dollars would be needed to repair U.S. concrete structures over the next 20 years [NMAB-437, 1987].

However, many of the problems encountered with existing concrete materials can be overcome in future construction projects by using a new type of concrete termed High Performance Concrete (HPC). The advantages of HPC are increased strength and 
durability and better overall performance characteristics [Moore, 1999], which in turn will result in increased safety and reduced life-cycle costs of structures.

Several states in United States have begun to use HPC in bridge construction. Four pioneering states are: Nebraska, New Hampshire, Texas, and Virginia. Their applications of HPC showed excellent results in strength, durability, and permeability.

In West Virginia, the Department of Highways (WVDOH) has developed specifications for class $\mathrm{H}$ high performance concrete as an initial reference to establish threshold mixture proportions. A large-scale and comprehensive 3-year study concerned with the development of HPC mixtures using locally available aggregate materials has also been initiated by the WVU College of Engineering and Mineral Resources research team listed at the end of this thesis. The purpose of this global research project using several aggregate materials available in the state is, to establish acceptable performance levels relevant to bridge deck concrete, and to develop specifications for various optimal HPC mixtures applicable to cast-in-place bridge decks in West Virginia. The most relevant performance requirements of HPC for bridge decks include strength, chloride permeability, and freeze-thaw durability.

The present study, which is part of the comprehensive program on HPC, was designed as an exploratory effort focusing on developing appropriate mixture proportions using limestone as one type of coarse aggregate abundant in West Virginia, natural sand, and both fly ash and slag. 


\subsection{Research Objective and Tasks}

The present exploratory study serves to establish a foundation for the future optimizations of HPC mix designs by providing guidelines for the most likely mix proportions to be developed using several WV aggregates. Through this exploratory study, the future work will be defined more effectively, and the complexity of the global research will be minimized. At the same time, and as part of the present study, an Advisory Panel for this project will be established, based on the exploratory research results that are to be presented in this thesis.

The present study was organized into the following three tasks:

1. Development of mixture proportions;

2. Evaluation of performance of mixtures;

3. Analysis of test results and selection of optimum mixes.

\subsection{Research Plan}

A total of six different mixtures were prepared using Type I portland cement. Three of them are using Class F fly ash to replace cement in the amounts of 15, 20, and 25 percent by weight; the other three are defined using blast furnace slag to replace cement in the amounts of 25,30 , and 35 percent by weight. One type of coarse aggregate consisting of $3 / 4$ inch graded limestone was used. Air entrainment and high range water reducer agent (HRWRA) were also used. All the mixtures were prepared using a constant water-cementitious ratio of 0.4 by weight. Each mixture was tested in the 
freshly mixed stage and hardened stage. In the fresh stage, the following tests were conducted: slump, air content, unit weight, and temperature. In the hardened stage, tests were conducted for compressive strength, rapid chloride permeability, shrinkage, and freeze-thaw cycles. The data from these tests was used to evaluate the performance of different mixtures and to establish the most optimum mixtures.

\subsection{Thesis Organization}

A review of the literature is presented in Chapter 2, in which, fundamentals of HPC as well as current research results and applications for HPC in bridge decks are presented. Chapter 3 presents the experimental program, including materials, sample preparation, and testing programs. Chapter 4 presents the test results and discussions. Chapter 5 summarizes the results of the entire research project covered in this thesis, followed by conclusions and recommendations for future work. 


\section{Chapter 2}

\section{Literature Review}

In this chapter, the definition of HPC by various agencies is discussed along with the information provided by the four lead states: Nebraska, New Hampshire, Texas, and Virginia. These state DOT's contributed significant research results on HPC. The reports on studies of HPC properties relevant to bridge applications are also reviewed, and HPC mixtures produced in few other states is also discussed. In addition the specifications by the West Virginia Department of Highways (WVDOH) for class H concrete (equivalent to HPC) that is currently in use is described in this chapter.

\subsection{Definition of HPC for Highway Structures}

The American Concrete Institute (ACI) [Russell, 1999] gives a definition of high-

performance concrete (HPC) as follows: HPC is a type of concrete that meets special combinations of performance and uniform requirements that cannot always be achieved routinely using conventional constituents and normal mixing, placing, and practices. According to ACI, the following criteria must be satisfied to make a HPC:

- Ease of placement

a Compaction without segregation

- Early age strength 
Long-term mechanical properties

ㄴ Low permeability

ㅁensity

- Heat of hydration

a Toughness

a Volume stability

- Long life in severe environment

The Strategic Highway Research Program (SHRP) [Zia, 1996] gives another definition for high-performance concrete using the following criteria:

- Maximum water-cementitious ratio (w/c) of 0.35

- Minimum durability factor of $80 \%$ as specified by ASTM C 666 Procedure A

․ Minimum strength criteria of either

(1) $21 \mathrm{MPa}(3,000 \mathrm{psi})$ within 4 hours after placement, which corresponds to very early strength (VES)

(2) $34 \mathrm{MPa}(5,000 \mathrm{psi})$ within 24 hours (high early strength or HES), or

(3) $69 \mathrm{MPa}(10,000 \mathrm{psi})$ within 28 days (very high strength or VHS)

It is noted that in the definition of HPC, the ACI cites fresh concrete properties, while the SHRP uses w/c as a mixing proportion criterion, but both cite long-term performance parameters. For bridge engineers to adopt a HPC performance definition, it must include adequate durability and strength parameters [Mather].

Goodspeed et al, 1996 proposed a definition of HPC for highway bridge applications. This definition is flexible and contains many variables, which allow designers the ability to choose different categories of performance. It consists of four 
strength parameters and four durability parameters as listed in the Table 2.1. The specialized series of concrete are designed to provide several benefits in the construction of concrete structures as listed in the table 2.2. The " Grades" of performance, which are chosen based on the needs of the structure and design, are listed in the Table 2.3 and Table 2.4.

Table 2.1 Definition of HPC for Highway Bridge (Goodspeed et al, 1996)

\begin{tabular}{||c|c||}
\hline STRENGTH CRITERIA & DURABILITY CRITERIA \\
\hline Compressive Strength & Freeze-thaw \\
\hline Modulus of Elasticity & Scaling \\
\hline Shrinkage & Abrasion \\
\hline Creep & Chloride Permeability \\
\hline
\end{tabular}

Table 2.2 Benefits of Using HPC in Highway Bridge Construction (Goodspeed et al, 1996)

\begin{tabular}{||c|c||}
\hline \hline PERFORMANCE BENEFITS & COST \& OTHER BENEFITS \\
Long-term mechanical properties & Less material \\
Early high strength & Fewer beams \\
Toughness & Reduced maintenance \\
Volume stability & Extended life cycle \\
Longer life in severe environments & Aesthetics \\
\hline
\end{tabular}


Table 2.3 FHWA HPC Performance Grades in SI Unit (Goodspeed et al, 1996)

\begin{tabular}{|c|c|c|c|c|}
\hline \multirow{2}{*}{$\begin{array}{c}\text { PERFORMANCE } \\
\text { CHARACTERISTIC }\end{array}$} & \multicolumn{4}{|c|}{ "FHWA HPC PERFORMANCE GRADES } \\
\hline & 1 & 2 & 3 & 4 \\
\hline $\begin{array}{c}\text { Freeze-thaw durability } \\
(\mathrm{x}=\text { relative dynamic modulus of } \\
\text { elasticity after } 300 \text { cycles })\end{array}$ & $60 \% \leq x<80 \%$ & $80 \% \leq x$ & & \\
\hline $\begin{array}{c}\text { Scaling resistance }^{2} \\
(\mathrm{x}=\text { visual rating of the surface } \\
\text { after } 50 \text { cycles })\end{array}$ & $x=4,5$ & $x=2,3$ & $\mathrm{x}=0,1$ & \\
\hline $\begin{array}{c}\begin{array}{c}\text { Abrasion resistance } \\
(\mathrm{x}= \\
\text { avg.depth of wear in } \mathrm{mm})\end{array} \\
\end{array}$ & $2.0>x \geq 1.0$ & $1.0>x \geq 0.5$ & $0.5>x$ & \\
\hline $\begin{array}{c}\text { Chloride penetration } \\
(\mathrm{x}=\text { coulombs })\end{array}$ & $3000 \geq x>2000$ & $2000 \geq x>800$ & $800 \geq x$ & \\
\hline $\begin{array}{c}\text { Strength }^{5}(\mathrm{MPa}) \\
(\mathrm{x}=\text { compressive strength })\end{array}$ & $41 \leq x<55$ & $55 \leq x<69$ & $69 \leq x<97$ & $x>97$ \\
\hline $\begin{aligned} & \text { Elasticity }^{6}(\mathrm{GPa}) \\
(\mathrm{x}= & \text { modulus of elasticity })\end{aligned}$ & $28 \leq x<40$ & $40 \leq x<50$ & $x \geq 50$ & \\
\hline $\begin{array}{c}\text { Shrinkage }^{7} \\
(\mathrm{x}=\text { microstrain })\end{array}$ & $800>x \geq 600$ & $600>x \geq 400$ & $400>x$ & \\
\hline $\begin{array}{c}\text { Creep }^{8}(\text { per MPa }) \\
(\mathrm{x}=\text { microstrain/pressure unit })\end{array}$ & $75 \geq x>60$ & $60 \geq x>45$ & $45 \geq x>30$ & $30 \geq x$ \\
\hline
\end{tabular}

Table 2.4 FHWA HPC Performance Grades in US Customary Unit (Goodspeed et al, 1996)

\begin{tabular}{|c|c|c|c|c|}
\hline \multirow{2}{*}{$\begin{array}{c}\text { PERFORMANCE } \\
\text { CHARACTERISTIC }\end{array}$} & \multicolumn{4}{|c|}{ FHWA HPC PERFORMANCE GRADE } \\
\hline & 1 & 2 & 3 & 4 \\
\hline $\begin{array}{c}\text { Freeze-thaw durability }^{1} \\
\text { (x= relative dynamic modulus } \\
\text { of elasticity after } 300 \text { cycles) }\end{array}$ & $60 \% \leq x<80 \%$ & $80 \% \leq x$ & & \\
\hline $\begin{array}{l}\text { Scaling resistance } \\
(\mathrm{x}=\text { visual rating of the } \\
\text { surface after } 50 \text { cycles })\end{array}$ & $x=4,5$ & $x=2,3$ & $\mathrm{x}=0,1$ & \\
\hline $\begin{array}{c}\text { Abrasion resistance }^{3} \\
(\mathrm{x}=\text { avg.depth of wear in } \\
\text { inches })\end{array}$ & $2 / 25>x \geq 1 / 25$ & $1 / 25>x \geq 1 / 50$ & $1 / 50>x$ & \\
\hline $\begin{array}{c}\text { Chloride penetration } \\
(\mathrm{x}=\text { coulombs })\end{array}$ & $3000 \geq x>2000$ & $2000 \geq x>800$ & $800 \geq x$ & \\
\hline 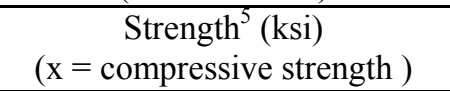 & $6 \leq x<8$ & $8 \leq x<10$ & $10 \leq x<14$ & $x \geq 14$ \\
\hline $\begin{array}{c}\text { Elasticity }^{6} \text { (psi) } \\
(\mathrm{x}=\text { modulus of elasticity })^{\text {modul }}\end{array}$ & $4 \leq x<6 \times 10^{6}$ & $6 \leq x<7.5 \times 10^{6}$ & $x \geq 7.5 \times 10^{6}$ & \\
\hline $\begin{array}{c}\text { Shrinkage }^{7} \\
(\mathrm{x}=\text { microstrain })\end{array}$ & $800>x \geq 600$ & $600>x \geq 400$ & $400>x$ & \\
\hline $\begin{array}{c}\text { Creep }^{8} \text { (per psi) } \\
(\mathrm{x}=\text { microstrain/pressure unit })\end{array}$ & $0.52 \geq x>0.41$ & $0.41 \geq x>0.31$ & $0.31 \geq x>0.21$ & $0.21 \geq x$ \\
\hline \multicolumn{5}{|c|}{$\begin{array}{l}\text { (Blank cell indicating the grade not apply to the corresponding performance characteristic) } \\
{ }^{2} \text { Test in accordance to AASHTO T } 161 \text { (ASTM C } 666 \text { Procedure A) } \\
{ }^{2} \text { Test in accordance to ASTM C } 672 \\
{ }^{3} \text { Test in accordance to ASTM C } 944 \\
{ }^{4} \text { Test in accordance to AASHTO T } 277 \text { (ASTM C 1202) } \\
{ }^{5} \text { Test in accordance to AASHTO T2 (ASTM C 39) } \\
{ }^{6} \text { Test in accordance to ASTM C } 469 \\
{ }^{7} \text { Test in accordance to ASTM C } 157 \\
{ }^{8} \text { Test in accordance to ASTM C } 512\end{array}$} \\
\hline
\end{tabular}




\subsection{Research on High Performance Concrete Mixtures}

There have been a number of studies focused on high performance concrete mixtures.

Ozyildirim 1988 studied the potential use of several supplemental cementitious materials to increase the resistance of hydraulic-cement concrete to penetration of chloride ions. The materials included Class F Fly ash, silica fume, ground granulated iron blast furnace slag, type I cement and type II cement, crushed granite gneiss, and siliceous sand.

The mixture proportions he studied were as follows:

1) $5 \%$ of the cement by mass was replaced with 1.2 times that mass by a Class $\mathrm{F}$ fly ash;

2) $25 \%$ of the cement by mass was replaced with 1.2 times that mass by a Class $F$ fly ash;

3) $50 \%$ of the cement by mass was replaced with slag;

4) $7 \%$ of the cement by mass was replaced with silica fume.

Each combination of materials with type II cement was tested at w/c ratio of 0.35 , 0.40 , and 0.45 . Each combination with type I cement was tested at a w/c ratio of 0.40 . To investigate the effect of curing temperatures, specimens were prepared using control concrete as well as concrete with $15 \%$ fly ash, $50 \%$ slag, and $7 \%$ silica fume, and with type II and type III cements at a w/c ratio of 0.40 . Three temperature levels of $40{ }^{\circ} \mathrm{F}$ ( 4 $\left.{ }^{\circ} \mathrm{C}\right), 73^{\circ} \mathrm{F}\left(23{ }^{\circ} \mathrm{C}\right)$ and $100{ }^{\circ} \mathrm{F}\left(38^{\circ} \mathrm{C}\right)$, were considered. 
All concrete contained an air entraining and a water-reducing admixture. The 2inch specimens, for rapid chloride permeability test, were cut from the top of a 4-inch by 8-inch cylinders after two weeks of moist curing. The side surface of the specimens was coated with an epoxy resin to prevent lateral moist loss. They were set on a plastic sheet, and were kept in ambient laboratory conditions until the time of test. Compressive strength was determined at ages of $1,7,28,90$, and 365 days.

The following results were obtained:

1) Chloride permeability: The Coulomb value (denoted by Q) was reduced as the w/c ratio was decreased. Concrete with pozzolans and slag had lower Q values than the controls, and Q values were decreased as the age of the specimens was increased from 28 days to 90 days. The 365 -day results were inconclusive as to whether changes in permeability occurred after 90 days.

2) Strength: Concrete with fly ash and slag had lower early strengths but generally higher ultimate strengths than the controls. For concrete containing silica fume, strengths were about the same or slightly higher at all ages.

3) Relation of strength to chloride permeability: For the same type and amount of supplemental cementitious materials, the $\mathrm{Q}$ values were decreased as strength was increased, indicating an inverse relationship between chloride permeability and strength. However, there was no specific relationship between the Q values and strength.

4) Effects of curing temperature: For those concretes containing slag and silica fume with type II and type III cements, there was little difference in chloride permeability performance for the same concrete at temperatures of $73{ }^{\circ} \mathrm{F}(23$ 
$\left.{ }^{\circ} \mathrm{C}\right)$, and $100{ }^{\circ} \mathrm{F}\left(38{ }^{\circ} \mathrm{C}\right)$, but for concrete cured at $40{ }^{\circ} \mathrm{F}\left(4{ }^{\circ} \mathrm{C}\right)$, the chloride permeability was generally higher. However, fly ash concrete made with either cement showed a very significant reduction in $\mathrm{Q}$ values as the curing temperature was increased. When the fly ash concrete was cured at $40{ }^{\circ} \mathrm{F}\left(4^{\circ} \mathrm{C}\right)$ or $73{ }^{\circ} \mathrm{F}\left(23^{\circ} \mathrm{C}\right)$, chloride permeability was in the high range, but when it was cured at $100{ }^{\circ} \mathrm{F}\left(38^{\circ} \mathrm{C}\right)$, the $\mathrm{Q}$ values were in or very close to the very low range. In general, the strengths of all concretes were highest when cured at 73 ${ }^{\circ} \mathrm{F}\left(23{ }^{\circ} \mathrm{C}\right)$.

Ozyildirim 1989 investigated whether the resistance to the penetration of chloride ions in the concrete with fly ash or slag could be improved by the addition of silica fume with either type II or type III cement. He also investigated whether early strengths of concrete with fly ash or slag could be improved by the addition of silica fume.

In his experimental program, 4 inch by 8 inch cylinders were made to test compressive strengths at $1,3,7,28$, and 90 days and chloride permeability at 28 and 90 days. For each concrete mixture, the total amount of cementitious material was 658 $\mathrm{lb} / \mathrm{yd}^{3}$, and the $\mathrm{w} / \mathrm{c}$ was 0.40 . The nominal maximum size of coarse aggregate was $1 / 2$ inch. Table 2.5 shows mixture proportions per cubic yard of concrete.

Table 2.5 Mixture Proportions per Cubic Yard of Concrete (unit: $1 \mathrm{~b} / \mathrm{yd}^{3}$ )

\begin{tabular}{||c|c|c|c|c|c|c|c||}
\hline \hline Identification & Cement & Water & Fly Ash & Slag & $\begin{array}{c}\text { Silica } \\
\text { Fume }\end{array}$ & $\begin{array}{c}\text { Fine } \\
\text { Aggregate }\end{array}$ & $\begin{array}{c}\text { Coarse } \\
\text { Aggregate }\end{array}$ \\
\hline Control & 658 & 263 & ----- & ----- & ----- & 1432 & 1506 \\
\hline $25 \mathrm{~F}$ & 494 & 263 & 164 & ----- & ----- & 1377 & 1506 \\
\hline $50 \mathrm{~S}$ & 329 & 263 & ----- & 329 & ----- & 1413 & 1506 \\
\hline $5 \mathrm{SF}$ & 625 & 263 & ----- & ----- & 33 & 1422 & 1506 \\
\hline $20 \mathrm{~F}-5 \mathrm{SF}$ & 494 & 263 & 132 & ----- & 33 & 1377 & 1506 \\
\hline 45S-5SF & 329 & 263 & ----- & 296 & 33 & 1404 & 1506 \\
\hline
\end{tabular}

Note: 1 1.Type III cement used for all combinations. Additional specimens for control, 20F-5SF, and 45S-53F was with Type II cement, 
2. Numbers in the first column indicate the percentage of the supplemental material by mass in the total cementitious material, $\mathrm{F}=$ fly ash, $\mathrm{S}=$ slag, $\mathrm{SF}=$ silica fume.

In the chloride permeability study, specimens from the same batch of concrete were cured in two different ways. In the first curing procedure, specimens were moist cured for one day and then air-dried until tested. In the second curing procedure, specimens were moist cured for 14 days and then air-dried until tested. After the moist curing, the top 2 inch of the cylinders was cut off and used as the test specimens.

The following results were found in his study:

1) Lower permeability is attained by the addition of silica fume in the amount equal to $5 \%$ of the cementitious materials in both fly ash and slag concrete. The reduction in the chloride permeability of the specimens containing fly ash and silica fume is of particular significance. Specimens containing $25 \%$ fly ash had high chloride permeability, while those containing $20 \%$ fly ash and $5 \%$ silica fume had low chloride permeability (about1000 to 1300 coulombs at 28 days). Specimens with a combination of $45 \%$ slag and $5 \%$ silica fume showed a further reduction in chloride permeability, and for either curing procedure, the values for permeability were below 800 coulombs at 28 days.

2) For concrete specimens made with type II cement, there were significant differences in permeability between those moist-cured for one day and those moist-cured for 14 days. However, for concrete made with type III cement, the moist-cured specimens for one day provided low chloride permeability.

3) Silica fume increased the strength of similar concrete to some degree, but not large. 
4) Except for those specimens containing slag, one-day strengths higher than 3000 psi are obtainable, with a w/c of 0.40 , in all the tested concrete with type III cement as well as the control concrete with type II cement. Concrete with slag and silica fume reached compressive strength of 3000 psi in a little more than 2 days.

Ozyildirim, 1994 evaluated the strength and the permeability of various combinations of silica fume and slag in concrete. He found that when silica fume is added in small amounts, $3 \%$ to $5 \%$, to concrete with up to $47 \%$ slag at a water-cement ratio from 0.40 to 0.45 , economical concretes with very low permeability ( 353 coulombs at 28 days) and adequate strength (55.6 MPa or $8050 \mathrm{psi})$ can be produced.

He also found that curing concrete containing silica fume and slag at a temperature that is higher than room temperature for some initial curing period is beneficial, in that lower permeability will be developed within 28 days. In his study, it was found that concrete cured for the first 3 days at $38^{\circ} \mathrm{C}\left(100{ }^{\circ} \mathrm{F}\right)$ had a permeability ranging from 353 to 589 coulombs for type III cement and 536 to 1166 coulombs for type II cement. He indicated that concrete with slag and silica fume had a lower permeability when steamcured compared to moist-cured at room temperature.

Naik et al., 1994 studied the influence of addition of a class C fly ash on concrete strength and permeability. Fine aggregate with a $6.35-\mathrm{mm}$ maximum size of natural sand and coarse aggregates with $25-\mathrm{mm}$ nominal maximum size of rounded and crushed limestone were used in the mixtures. A superplasticizer and an air-entraining agent were 
also added in each mix. The concrete mixtures were proportioned to replace cement with Class $\mathrm{C}$ fly ash in the range from 0 to $70 \%$ by weight. For each concrete mixture, compressive strength, chloride permeability, air permeability, and water permeability were determined.

They found the following results:

1. At ages up to 28 days, no-fly ash concrete attained lower air permeability and water permeability compared to high volume fly ash concrete. At age of 91 days, the mixture having $50 \%$ cement replacement exhibited the lowest air permeability and water permeability, the high volume fly ash concrete having $50 \%$ cement replacement showed lowest permeability (coulomb value was 2000) to chloride ions among all the mixtures tested;

2. In general, the high volume fly ash concrete attained lower strengths compared to the concrete without fly ash. At age of 90 days, the strength of the concrete with $70 \%$ of fly ash was about 5200 psi, and the strength of the concrete without fly ash was almost 6800 psi.

3. Test results revealed that concrete permeability was not strongly correlated to compressive strength, especially at later age.

Cabrera et al., 1997 made a laboratory study on the strength and chloride permeability resistance of fly ash and Ordinary Portland Cement (OPC) concrete and mortars. Concrete was exposed to salt water to record diffusion measurement data under two simulated exposure conditions: a) intermittent splashing, b) capillary-osmosis absorption, both of which were attempted to simulate site exposure conditions. During 
their study, the unique advantage of fly ash as a workability enhancer was confirmed, i.e. the reduction of the water content without impairing the concrete workability. Also they found that concrete with $33 \%$ replacement of OPC by fly ash gave the same compressive strengths as OPC mixtures at 28 days. The chloride diffusion coefficient of OPC concrete was reduced from $25 \%$ to $42 \%$ by the substitution of OPC with fly ash.

\subsection{High Performance Concrete Bridge Decks in Four Lead States}

Researches over the past twenty years have shown that HPC has superior properties to normal performance concrete. The Federal Highway Administration (FHWA) initiated a national program in 1994 to implement high-performance concrete (HPC) in highway bridge [Moore, 1999]. In order to promote the implementation of HPC technology for use in highways and highway structures, the American Association of State Highways and Transportation Officials (AASHTO) Task Force on Strategic Highway Research Program (SHRP) Implementation, in conjunction with FHWA and its transportation research board, established a HPC lead state team in 1996 to coordinate the effort.

Due to this collaborative effort, HPC was successfully used for bridge deck construction in the four lead states including Virginia [Ozyildirim, 1999], Nebraska [Beacham, 1999], New Hampshire [Waszczuk, et al., 1999] and Texas [Ralls, 1999].

Since durability and strength are the most important aspects of HPC, all of the four lead states focused their concrete research and development on these two issues. The mixture proportions of HPC developed by these four states are summarized in Table 2.6. The compressive strength and the permeability results are also furnished in Table 2.7. 
Table 2.6 Four Lead States Mixture Proportions

\begin{tabular}{|c|c|c|c|c|c|c|c|c|c|c|}
\hline \multirow[b]{2}{*}{ STATE } & CEMENT & $\begin{array}{l}\text { FLY } \\
\text { ASH }\end{array}$ & SLAG & $\begin{array}{c}\text { COARSE } \\
\text { AGGREGATE }\end{array}$ & $\begin{array}{c}\text { FINE } \\
\text { AGGREGATE }\end{array}$ & $\begin{array}{c}\text { AIR } \\
\text { ENTR. }\end{array}$ & WRA & RETARD & HRWRA & $\mathrm{W} / \mathrm{CM}$ \\
\hline & $\left(\mathrm{lb} / \mathrm{yd}^{3}\right)$ & $\left(\mathrm{lb} / \mathrm{yd}^{3}\right)$ & $\left(\mathrm{Ib} / \mathrm{yd}^{3}\right)$ & $\left(\mathrm{lb} / \mathrm{yd}^{3}\right)$ & $\left(\mathrm{lb} / \mathrm{yd}^{3}\right)$ & $\mathrm{OZ}$ & $\mathrm{OZ}$ & $\mathrm{oz} / \mathrm{yd}^{3}$ & $\mathrm{oz} / \mathrm{yd}^{3}$ & \\
\hline \multirow{2}{*}{ Virginia } & 329 & & 329 & $1774(\mathrm{~N} / \mathrm{A})$ & 1173 & & & & & 0.4 \\
\hline & 329 & & 329 & 1787 (N/A) & 1158 & & & & & 0.38 \\
\hline $\begin{array}{c}\text { New } \\
\text { Hampshire }\end{array}$ & 506 & & & $1388(\mathrm{~L})$ & 910 & 5 & 20 & & 158 & 0.384 \\
\hline \multirow{5}{*}{ Texas } & 383 & 148 & & $1856(\mathrm{~L})$ & 1243 & 2.6 & & 45 & None & 0.43 \\
\hline & 474 & 221 & & $1810(\mathrm{~L})$ & 1303 & None & & 22 & 160 & 0.35 \\
\hline & $\begin{array}{c}492 \\
\text { (Type II) }\end{array}$ & 211 & & $1900(\mathrm{G})$ & 1216 & 3.9 & & 28 & 204 & 0.31 \\
\hline & $\begin{array}{c}427 \\
\text { (Type II) }\end{array}$ & 184 & & $1856(\mathrm{G})$ & 1239 & 3.9 & & 26 & None & 0.42 \\
\hline & $\begin{array}{c}610 \\
\text { (Type II) } \\
\end{array}$ & 0 & & $1856(\mathrm{G})$ & 1243 & 3.9 & & 26 & None & 0.42 \\
\hline Nebraska & $\begin{array}{c}754 \\
\text { (Type IP) }\end{array}$ & 76 & & $1400(\mathrm{~L})$ & 1409 & & & 30 & 135 & 0.38 \\
\hline
\end{tabular}

Note: L-Limestone; G-Gravel

Table 2.7 Compressive Strength and Rapid Chloride Permeability Results of Lead States

\begin{tabular}{|c|c|c|}
\hline STATE & $\begin{array}{c}28-\mathrm{D} \\
\text { COMPRESSIVE STRENGTH } \\
\text { (PSI) }\end{array}$ & $\begin{array}{c}28-\mathrm{D} \\
\text { COULOMB VALUE }\end{array}$ \\
\hline \multirow{2}{*}{ Virginia } & 8710 & 898 \\
\hline & 6680 & 983 \\
\hline New Hampshire & $8163-9614$ & $609-896$ \\
\hline \multirow{5}{*}{ Texas } & $>4060$ & 1730 \\
\hline & $>4060$ & 900 \\
\hline & $>4060$ & 690 \\
\hline & 4060 & 1380 \\
\hline & 4060 & 2490 \\
\hline Nebraska & $9133(56-d)$ & $598(56-d)$ \\
\hline
\end{tabular}

\subsection{HPC Bridge Decks in Other States}

The showcases of the four lead states promoted HPC technology by demonstrating the capabilities and cost effectiveness of this alternative to conventional concrete construction. To date, approximately 15 states (including the four lead states) have become involved with HPC in bridge construction. This section reviews the application 
of HPC in other three states, Florida, New York and Montana, as examples of the growing application of HPC in bridge deck construction.

\subsubsection{Florida HPC Experience}

Due to severe deterioration along the coastline and intracoastal waterways, the Florida State Department of Transportation (FDOT) initiated the research on HPC by using fly ash in the 1970's [Larsen, 1995]. They found that the addition of fly ash pozzolanic material benefited a structure in three ways: 1) improved its corrosion protective properties, 2) improved its sulfate resistance, 3) reduced the heat of hydration for equal 28 days strength [Larsen, 1987].

FDOT has focused their concrete research on the durability aspects of HPC, since this has greater potential for economic impact on their program than increased concrete design strength [Edwards, 2000]. In one project of the New Skyway Bridge, they kept the maximum water cementitious ratio as 0.44 with fly ash replacement from approximately $20 \%$ to $50 \%$ of total cementitious quantities. The mixture designs surpassed the highest concrete strength requirement for the structure was $38 \mathrm{MPa}(5500$ psi), the laboratory permeability testing showed that chloride penetration resistance of the HPC was within the Grade 1 range (see Table 2.3).

\subsubsection{New York State HPC Experience}

The New York State Department of Transportation began using HPC in 1994 to produce long-lasting and more durable bridge decks. Two materials were recommended 
for the application. One was concrete with low cement content using pozzolans as substitution for cement and low ratio of water to total cementitious materials while maintaining the workability by using water-reducing admixture. The concrete contains $20 \%$ Class F fly ash and $6 \%$ microsilica, with a total cementitious content of $405 \mathrm{Kg} / \mathrm{m}^{3}$ [Streeter, 1996]. The other material was the use of penetrating protective sealers. Use of protective sealers was deemed an appropriate means to protect "green" concrete from the early exposure to chloride. Curing period was increased from 7 days to 14 days. The performance of HPC in New York has been very good to date with some important characteristics as: average $28-\mathrm{d}$ compressive strength of $37.25 \mathrm{MPa}$ (5400 psi). Permeability in the field of $50 \%$ to $70 \%$ less than that of conventional concrete, average permeability of 1600 coulombs, and reduced shrinkage cracking [Streeter, 2000].

\subsubsection{Montana State HPC Experience}

The Montana Department of Transportation (MDT) started a HPC project in 1998 [Freeman, 1999]. The primary intention of their research was to decrease permeability, rather than increase compressive strength. Since very high strength concrete may cause drying and thermal shrinkage cracking problems. Four mixtures using two kinds of aggregates were designed: 1) "Special Deck Concrete" (SDC) mixture currently used for bridge decks in Montana; 2) HPC mixture with fly ash as the only mineral admixture; 3) HPC mixture with silica fume as the only mineral admixture; and 4) HPC mixture with both fly ash and silica fume. The mixture proportions are shown in Table 2.8. 
Table 2.8 Mixture Proportions in Montana State [Freeman, 1999]

\begin{tabular}{||c|c|c|c|c||}
\hline TYPE & $\begin{array}{c}\text { FLY ASH } \\
(\%)\end{array}$ & $\begin{array}{c}\text { SILICA } \\
\text { FUME (\%) }\end{array}$ & $\begin{array}{c}\text { MAXIMUM } \\
\text { W/(C+P) }\end{array}$ & SLUMP (MM) \\
\hline \hline Special Deck Concrete & 0 & 0 & 0.40 & 38 to 76 \\
\hline HPC with Fly Ash & 25 & 0 & 0.35 & 76 to 178 \\
\hline HPC with Silica fume & 0 & 10 & 0.35 & 76 to 178 \\
\hline HPC with Fly Ash and Silica fume & 15 & 10 & 0.35 & 76 to 178 \\
\hline
\end{tabular}

Note: Percentage replacement of cement by mass

All the HPC mixture proportions maintained the cement factor of 7 sacks/cy (390

$\mathrm{kg} / \mathrm{m}^{3}$ ). It was found that all three HPC mixtures had good workability and they met the current Montana Department of Transportation (MDT) specifications for bridge decks. The HPC mixtures generally had higher compressive strengths (average 28-day strength was $39.1 \mathrm{MPa}$ or $5670 \mathrm{psi}$ ) than the normal Portland cement concrete mixture (Special Deck Concrete), which had 28-day strength of $33.1 \mathrm{MPa}$ (4800 psi). The HPC with silica fume attained the highest strength at 7 days, which was $31.1 \mathrm{MPa}(4800 \mathrm{psi})$. The mixtures with highest strengths at 28 days and 56 days were those having silica fume and those with both fly ash and silica fume.

\subsection{West Virginia Division of Highways HPC Specifications}

The West Virginia Division of Highways (WVDOH) developed their own specifications for Class $\mathrm{H}$ concrete used in bridge decks. These specifications are discussed in detail in this section. 


\subsubsection{Materials}

The free moisture content of each aggregate type, at the time of batching, shall not exceed $7 \%$ of the saturated-surface dry weight of the fine or coarse aggregate, or $8 \%$ total for both aggregates. The sources of coarse aggregate shall be approved by WVDOH.

\subsubsection{Proportioning}

Class $\mathrm{H}$ concrete shall consist of a homogeneous mixture of cement, fine aggregate, coarse aggregate, micro silica admixture, and fly ash or ground granulated blast furnace slag, chemical admixtures and water.

Design mixture testing shall include air content, slump, and compressive strength results at 28 days and results of rapid chloride permeability tests (RCPT) at age of 35 to 42 days. The results of RCPT shall not exceed 750 coulombs. The 28-day compressive strength of the test mix that satisfies the 750 coulombs shall be accepted as Class $\mathrm{H}$ concrete. Table 2.9 summarizes these specifications.

Table 2.9 WVDOH Specifications of HPC

\begin{tabular}{||c|c||}
\hline SPECIFICATION ITEMS & VALUES \\
\hline \hline Class of Concrete & $\mathrm{H}$ \\
\hline Max W/(C+P) ratio & 0.40 \\
\hline Entrained Air (\%) & $6.5 \pm 0.5$ \\
\hline Max Slump (inch) & 7 \\
\hline Coulomb value of RCPT at 35-42 days & $<750$ \\
\hline Design 28-d compressive strength (psi) & $>4000$ \\
\hline
\end{tabular}

Note: $W=$ water, $C=$ cement,$P=$ pozzolans 


\subsubsection{Testing}

Compressive strengths shall be greater than eighty percent of the 28-day compressive strength of the approved test mix. Drying shrinkage test shall be tested at 1 , $4,7,14,28,56$, and 90 days. These tests shall be performed at the same frequency as the compressive tests.

Note: The chloride permeability requirement of less than 750 coulombs would correspond to the highest performance Grade 4 as suggested by FHWA (see Table 2.3) and this is an unrealistic expectation that will need to be revised.

\subsection{Significance of Current Research}

The present study is part of a comprehensive project on the development of HPC mixes for cast-in-place bridge decks in West Virginia, using locally available aggregate materials from different locations within the state, and fly ash, and/or slag available in the state. This is an exploratory study to establish appropriate mixture designs using limestone, a type of coarse aggregate abundant in West Virginia, natural sand, and both slag and fly ash. The West Virginia Department of Highways (WVDOH) specifications for class $\mathrm{H}$ concrete is used to establish threshold mixture proportions. The proposed HPC mixtures are studied for various parameters relevant to bridge deck concrete, including strength, chloride permeability, and freeze-thaw durability. From the results, the best possible combinations for fly ash and slag will be selected and used as prototypes to focus a subsequent global research program on HPC for the state of West Virginia. 


\section{Chapter 3}

\section{Experimental Program}

The materials, sample preparations, and testing of HPC mixtures are discussed in this chapter.

The testing procedures and materials used throughout this study are according to relevant ASTM and AASHTO specifications and standards. All materials and testing procedures also comply with the requirements of the West Virginia Division of Highways (WVDOH).

\subsection{Materials}

The primary Materials used in this experimental program, such as Portland cement, fly ash, slag, fine aggregate and coarse aggregate were supplied by Arrow Concrete Company, a local ready-mix concrete plant approved by the WVDOH. Chemical admixtures such as air entraining agent (AEA), high range water reducing agent (HRWRA), and silica fume were supplied by Master Builders Company (USA). The WVDOT-DOH uses concrete mixtures supplied by ready-mix companies like Arrow Concrete Company, for most of their Class $\mathrm{H}$ concrete. Most of the Class $\mathrm{H}$ concrete is mixed with chemical admixtures supplied by Master Builders Company. 


\subsubsection{Portland Cement}

Commercially available Type I Portland cement conforming to ASTM C 150 was used in this study. For the purpose of mixture proportioning a specific gravity of 3.15 was assumed. Table 3.1 lists the chemical compound composition of the Type I cement used in this study.

Table 3.1 Material Composition of Type I Portland Cement [Arrow Concrete Company]

\begin{tabular}{||c|c||}
\hline ELEMENT & PERCENTAGE (MASS) \\
\hline \hline Tricalcium Silicate & 49 \\
\hline Dicalcium Silicate & 25 \\
\hline Tricalcium Aluminate & 12 \\
\hline Tetracalcium Aluminoferrite & 8 \\
\hline Calcium Sulfate & 2.9 \\
\hline Calcium Oxide & 0.8 \\
\hline Magnesium Oxide & 2.4 \\
\hline
\end{tabular}

\subsubsection{Coarse Aggregate}

The coarse aggregate used in this study was graded limestone of $3 / 4$ inch nominal size known as Greer Limestone. Table 3.2 and Table 3.3 show some of the properties. Figure 3.1 shows the typical limestone coarse aggregate used in the study. 
Table 3.2 Properties of Coarse Aggregate (Limestone)[Arrow Concrete Company]

\begin{tabular}{||c|c||}
\hline PROPERTIES & VALUE \\
\hline Nominal Size & $3 / 4$ inch \\
\hline Absorption (\%) & $0.53 \%$ \\
\hline SSD Specific Gravity & 2.690 \\
\hline Bulk Specific Gravity & 2.680 \\
\hline Apparent Specific Gravity & 2.719 \\
\hline
\end{tabular}

Table 3.3 Sieve Analysis of Coarse Aggregate [Arrow Concrete Company]

\begin{tabular}{||c|c|c|c||}
\hline & \multicolumn{2}{|c|}{ SPECIFICATIONS } & PERCENTAGE PASSING \\
\hline Sieve Size & Low & High & Greer \#57 (L) \\
\hline \hline $1 "$ & 95 & 100 & 100 \\
\hline $3 / 4 "$ & - & - & - \\
\hline $5 / 8^{\prime \prime}$ & - & - & 73 \\
\hline $1 / 2^{\prime \prime}$ & 25 & 60 & 45 \\
\hline $3 / 8^{\prime \prime}$ & - & - & - \\
\hline$\# 4$ & 0 & 10 & 1 \\
\hline$\# 8$ & 0 & 5 & 3 \\
\hline
\end{tabular}

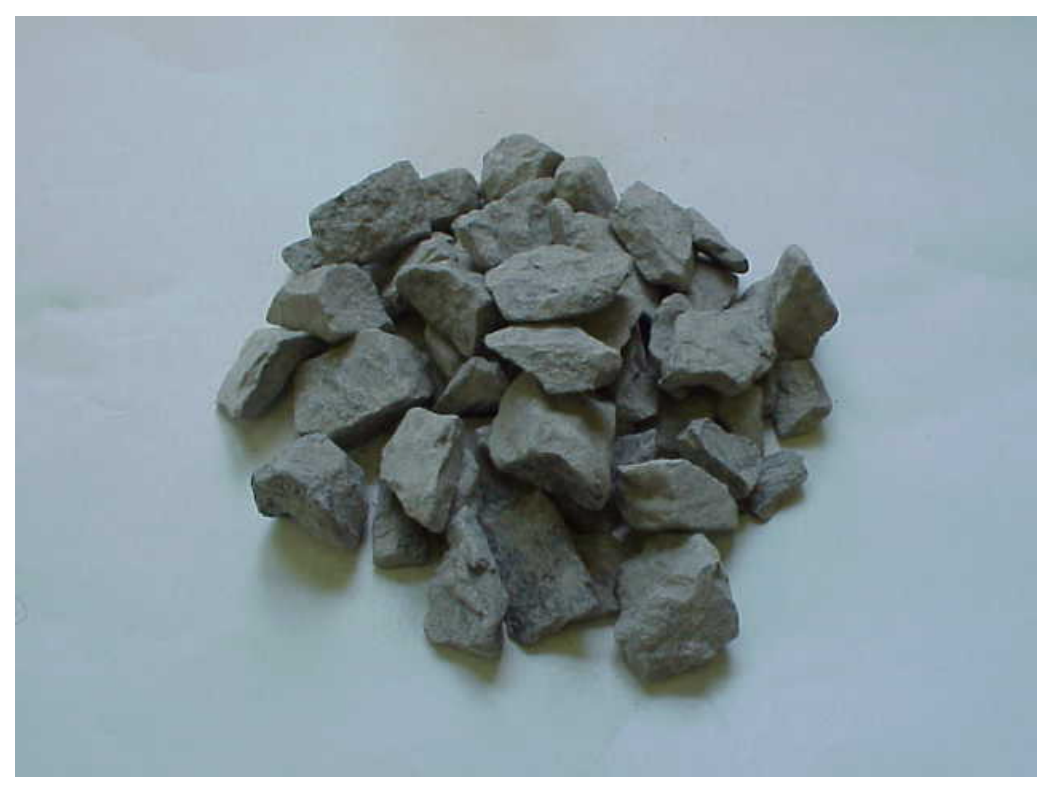

Figure 3.1 Graded Limestone of $3 / 4$ inch Size 


\subsubsection{Fine Aggregate}

The fine aggregate used in this experimental program was graded river sand of 3/8 inch nominal size with some of the properties shown in Table 3.4 and Table 3.5.

Figure 3.2 shows the typical sand used in the study.

Table 3.4 Properties of Fine Aggregate [Arrow Concrete Company]

\begin{tabular}{||c|c|}
\hline PROPERTIES & VALUE \\
\hline \hline Absorption & $100 \%$ \\
\hline SSD Specific Gravity & 2.611 \\
\hline Bulk Specific Gravity & 2.586 \\
\hline Apparent Specific Gravity & 2.653 \\
\hline
\end{tabular}

Table 3.5 Sieve Analysis of Fine Aggregate [Arrow Concrete Company]

\begin{tabular}{||c|c|c|c||}
\hline & \multicolumn{2}{|c|}{ SPECIFICATIONS } & PERCENTAGE PASSING \\
\hline Sieve & Low & High & River Sand \\
\hline \hline $3 / 8 "$ & 100 & 100 & 100 \\
\hline$\# 4$ & 95 & 100 & 97.2 \\
\hline$\# 8$ & 80 & 100 & 82.3 \\
\hline$\# 16$ & 50 & 85 & 69 \\
\hline$\# 30$ & 25 & 60 & 54.6 \\
\hline$\# 50$ & 5 & 30 & 16.1 \\
\hline$\# 100$ & 0 & 10 & 2 \\
\hline$\# 200$ & - & - & 0.7 \\
\hline FM & 2.3 & 3.1 & 2.79 \\
\hline \hline
\end{tabular}




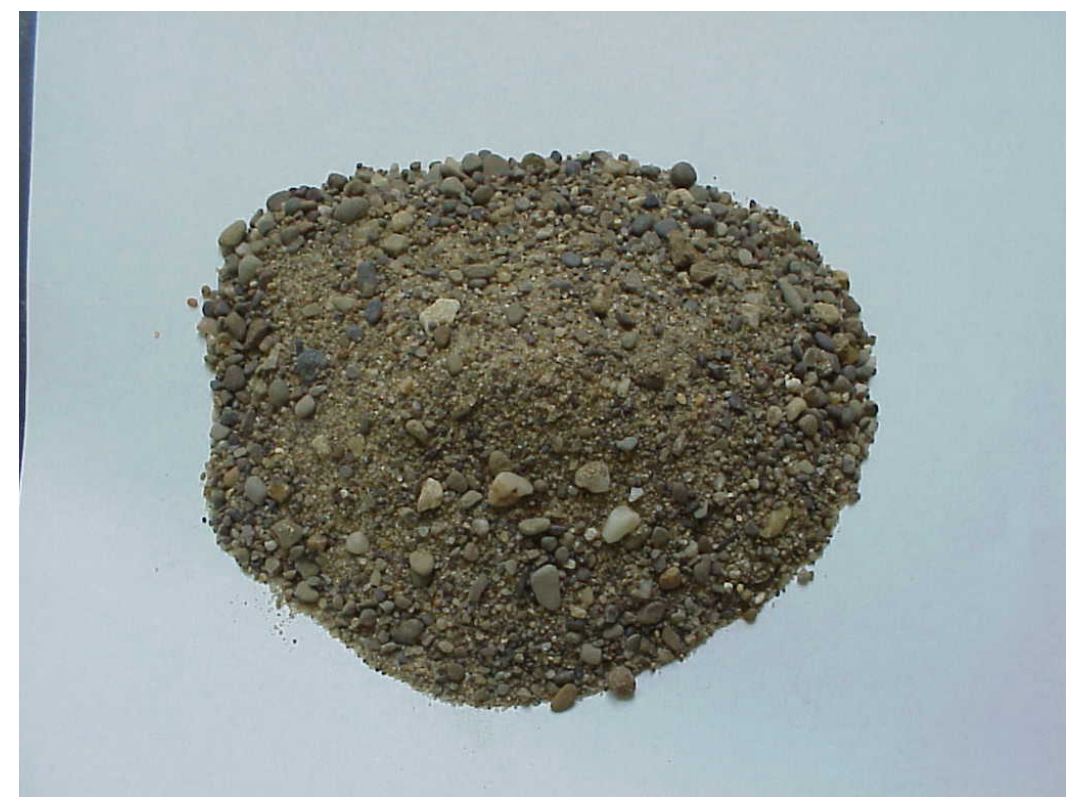

Figure 3.2 Typical River Sand

\subsubsection{Fly Ash}

The Class F fly ash used in this study conformed to ASTM C 618 (Standard Specification for Coal Fly Ash and Raw or Calcined Natural Pozzolan for Use as a Mineral Admixture in Portland Cement Concrete). The specific gravity of the fly ash was 2.4.

\subsubsection{Slag}

The ground granulated blast-furnace slag used in this study conformed to ASTM C989 (Standard Specification for Ground Granulated Blast-Furnace Slag for Use in Concrete). The specific gravity of the slag was 2.8 . 


\subsubsection{Silica Fume}

The silica fume used in this study conformed to ASTM C 1240 (Standard Specification for Use of Silica Fume as a Mineral Admixture in Hydraulic Cement Concrete, Mortar, and Grout). The specific gravity of the silica fume was 2.2.

Figure 3.3, 3.4, and 3.5, respectively, show the typical fly ash, slag, and silica fume used in this study.

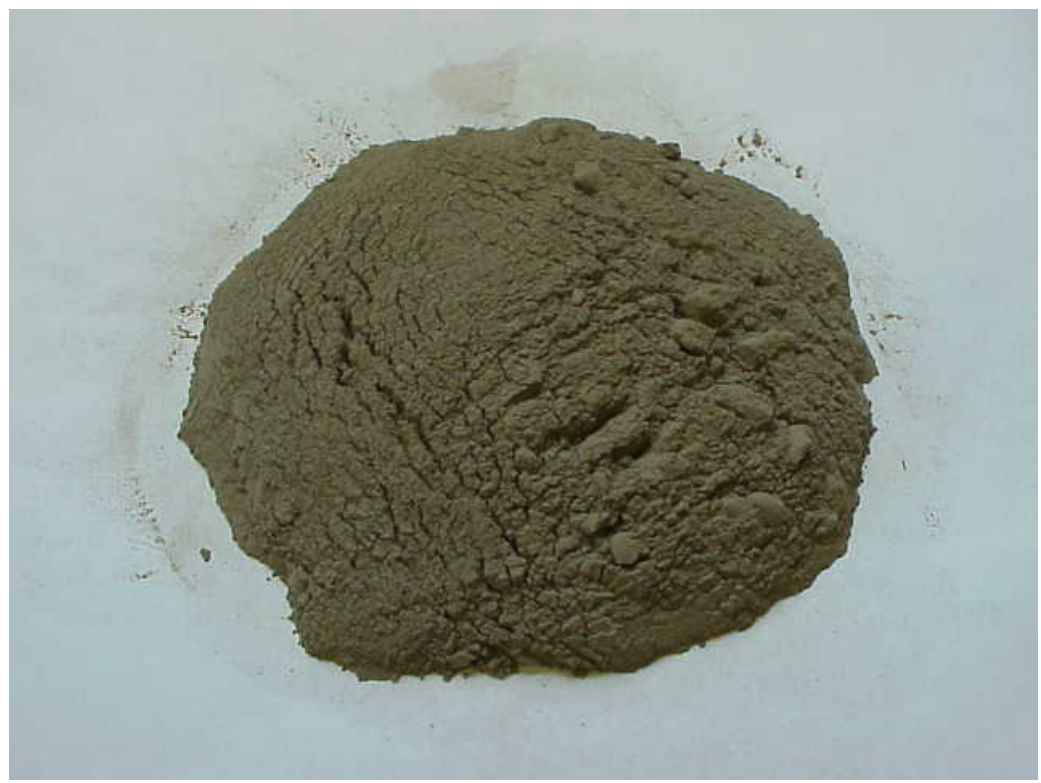

Figure 3.3 Class F Fly Ash 


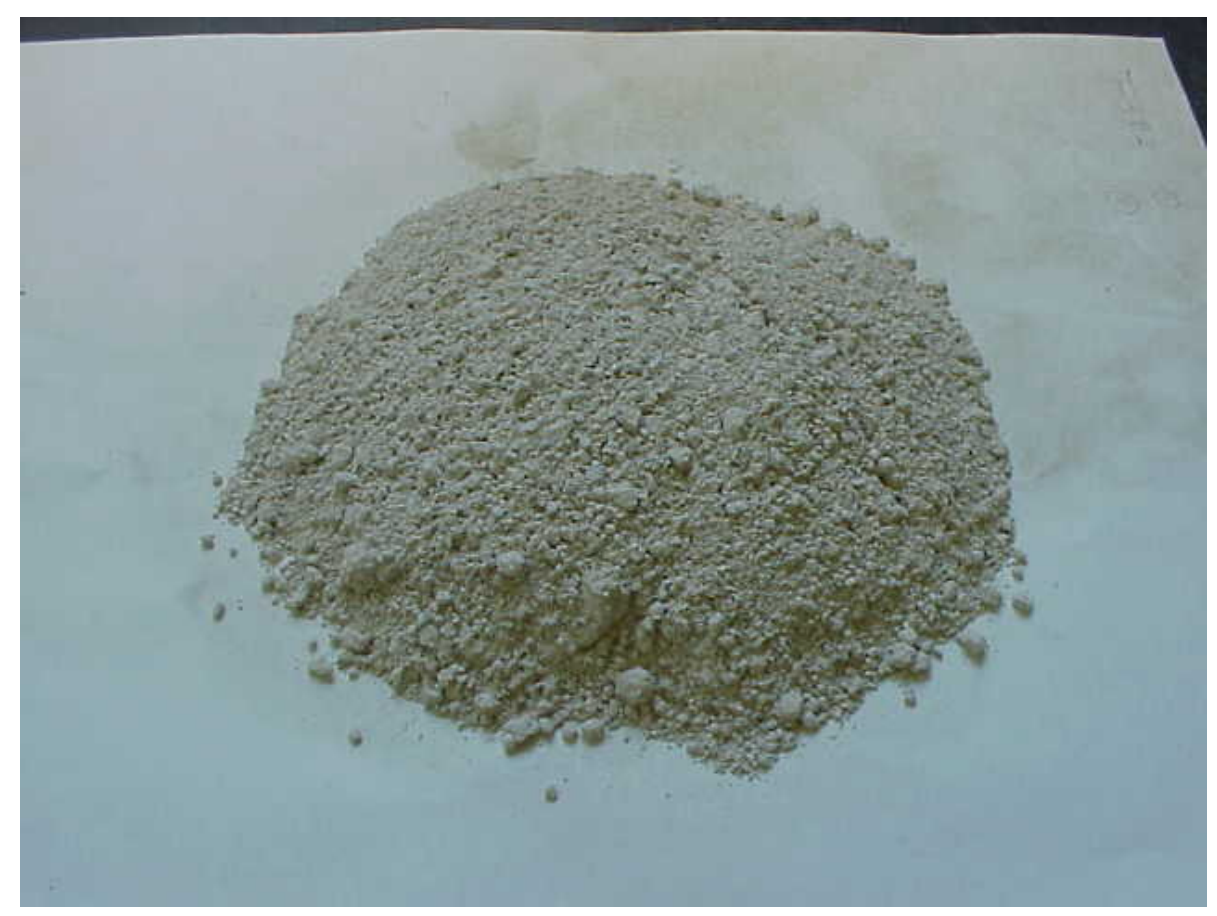

Figure $3.4 \quad$ Slag

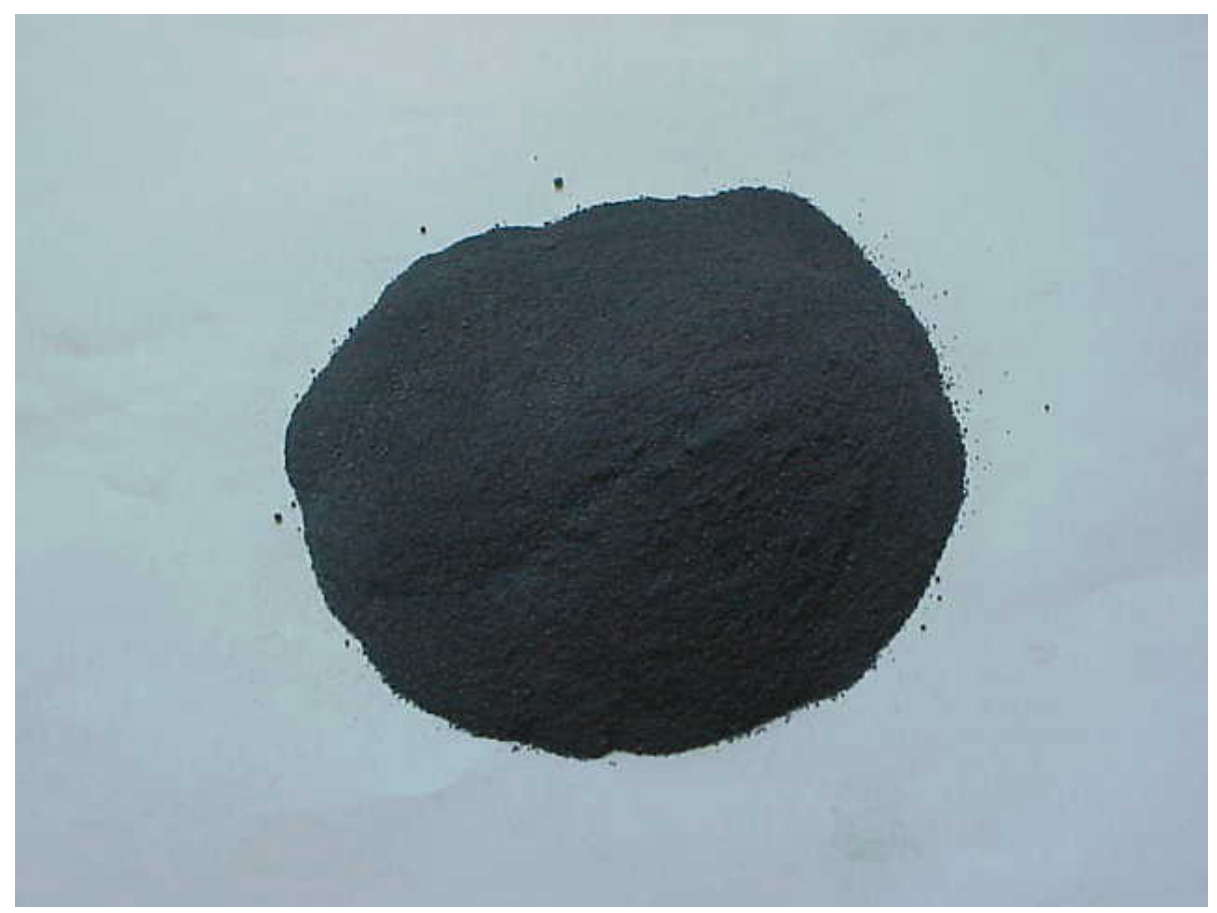

Figure 3.5 Silica Fume 


\subsubsection{Chemical Admixtures}

Two chemical admixtures were used in the experimental program: high range water reducing agent (HRWRA) and air entraining agent (AEA). The HRWRA used in the mixtures was a naphthalene-based superplasticizer conforming to ASTM C 494 type F. The air-entraining agent (AEA) used was based on neutralized vinsol resin meeting the requirements of ASTM C 260.

\subsubsection{Mixing Water}

The mixing water used in this study was tap water from the Morgantown city water supply and was assumed to have a specific gravity of $62.4 \mathrm{lbs}$ per cubic foot (1000 kg per cubic meter).

\subsection{Mixture Proportions}

A total of six mixtures were prepared for the study, three with fly ash and other three with slag. One of the three mixtures for each fly ash and slag was made according to the WVDOT-DOH specifications for Class $\mathrm{H}$ concrete and was used as a reference recipe. The other mixtures were developed by varying the quantity of fly ash or slag while keeping the quantity of cementitious material and water-cementitious ratio constants. In all the mixtures, the slump and air content values were maintained within a close range. This was done to facilitate the direct comparisons among the mixtures. In order to achieve a uniform range of slump, the quantity of HRWRA was varied. The 
quantity of fine aggregate was adjusted to maintain the yield of the mixtures. The mixtures considered are as follows:

\section{Group F: Fly Ash Group}

ㄱ1: Cement/Fly ash/Silica fume $=75 / 20 / 05$ (by weight)

This mix design is based on WVDOT-DOH specifications for class $\mathrm{H}$ concrete, and is considered a reference mixture for group F.

ㄱ: Cement/Fly ash/Silica fume $=70 / 25 / 05$ (by weight)

- F3: Cement/Fly ash/Silica fume $=80 / 15 / 05$ (by weight)

\section{Group S: Slag Group}

- S1: Cement/Slag/Silica fume $=65 / 30 / 05$ (by weight)

This mix design is based on WVDOT-DOH specifications for class $\mathrm{H}$ concrete, and is considered a reference mixture for group S.

口 S2: Cement/Slag/Silica fume $=60 / 35 / 05$ (by weight)

- S3: Cement/Slag/Silica fume $=70 / 25 / 05$ (by weight)

The quantities of fine aggregate, coarse aggregate, high range water reducing agent (HRWRA), and air-entraining agent (AEA) were finalized through several trial mixes in the laboratory and guidelines obtained from the studies of the four lead states. A slump of 5 to 7 inches and air content of $5 \%$ to $8 \%$ as specified for Class $\mathrm{H}$ concrete by the WVDOT-DOH were maintained for all the mixtures. The mixing proportions are given in table form as follows: 
Table 3.6a Mixture Proportion of Group F in US Customary Units

\begin{tabular}{||c|c|c|c|c|c|c|c|c|c||}
\hline MIX & CEMENT & $\begin{array}{c}\text { FLY } \\
\text { ASH }\end{array}$ & $\begin{array}{c}\text { SILICA } \\
\text { FUME }\end{array}$ & WATER & $\begin{array}{c}\text { COARSE } \\
\text { AGGREGATE }\end{array}$ & $\begin{array}{c}\text { FINE } \\
\text { AGGREGATE }\end{array}$ & $\begin{array}{c}\text { AIR } \\
\text { ENTR. }\end{array}$ & HRWRA & W/C \\
\hline \hline & $($ Lbs $)$ & $($ Lbs $)$ & $($ Lbs $)$ & $($ Lbs $)$ & $($ Lbs $)$ & $($ Lbs $)$ & Oz. & Oz. & \\
\hline F1 & 470 & 124 & 30 & 250 & 1750 & 1206 & 18 & 100 & 0.4 \\
\hline F2 & 438 & 156 & 30 & 250 & 1750 & 1221 & 20 & 75 & 0.4 \\
\hline F3 & 500 & 94 & 30 & 250 & 1750 & 1214 & 20 & 108 & 0.4 \\
\hline
\end{tabular}

Note: All values are based on one cubic yard of concrete. Cm=cementitious material=Cement + fly ash or slag+ silica fume

Table 3.6b Mixture Proportion of Group F in SI Units

\begin{tabular}{||c|c|c|c|c|c|c|c|c|c||}
\hline MIX & CEMENT & $\begin{array}{c}\text { FLY } \\
\text { ASH }\end{array}$ & $\begin{array}{c}\text { SILICA } \\
\text { FUME }\end{array}$ & WATER & $\begin{array}{c}\text { COARSE } \\
\text { AGGREGATE }\end{array}$ & $\begin{array}{c}\text { FINE } \\
\text { AGGREGATE }\end{array}$ & AEA & HRWRA & W/C \\
\hline \hline & $(\mathrm{Kg})$ & $(\mathrm{Kg})$ & $(\mathrm{Kg})$ & $(\mathrm{Kg})$ & $(\mathrm{Kg})$ & $(\mathrm{Kg})$ & $\mathrm{ml}$ & $\mathrm{ml}$ & \\
\hline F1 & 279 & 74 & 18 & 148 & 1038 & 716 & 696 & 3868 & 0.4 \\
\hline F2 & 260 & 93 & 18 & 148 & 1038 & 724 & 773 & 2907 & 0.4 \\
\hline F3 & 297 & 56 & 18 & 148 & 1038 & 720 & 773 & 4183 & 0.4 \\
\hline
\end{tabular}

Note: All values are based on one cubic meter of concrete. Cm=cementitious material= Cement + fly ash or slag+ silica fume

Table 3.7a Mixture Proportion of Group S in US Customary Units

\begin{tabular}{||c|c|c|c|c|c|c|c|c|c||}
\hline \hline MIX & CEMENT & $\begin{array}{c}\text { SLAG } \\
\text { ASH }\end{array}$ & $\begin{array}{c}\text { SILICA } \\
\text { FUME }\end{array}$ & WATER & $\begin{array}{c}\text { COARSE } \\
\text { AGGREGATE }\end{array}$ & $\begin{array}{c}\text { FINE } \\
\text { AGGREGATE }\end{array}$ & $\begin{array}{c}\text { AIR } \\
\text { ENTR }\end{array}$ & HRWRA & W/C \\
\hline \hline & $($ Lbs $)$ & $($ Lbs $)$ & $($ Lbs $)$ & $($ Lbs $)$ & $($ Lbs $)$ & $($ Lbs $)$ & Oz. & Oz. & \\
\hline S1 & 423 & 194 & 30 & 259 & 1750 & 1178 & 38 & 82 & 0.4 \\
\hline S2 & 391 & 226 & 30 & 259 & 1750 & 1174 & 35 & 105 & 0.4 \\
\hline S3 & 455 & 162 & 30 & 259 & 1750 & 1198 & 38 & 97 & 0.4 \\
\hline
\end{tabular}

Note: All values are based on one cubic yard of concrete. Cm= cementitious material= Cement + fly ash or slag+ silica fume

Table 3.7b Mixture Proportion of Group S in SI Units

\begin{tabular}{||c|c|c|c|c|c|c|c|c|c||}
\hline \hline MIX & CEMENT & $\begin{array}{c}\text { FLY } \\
\text { ASH }\end{array}$ & $\begin{array}{c}\text { SILICA } \\
\text { FUME }\end{array}$ & WATER & $\begin{array}{c}\text { COARSE } \\
\text { AGGREGATE }\end{array}$ & $\begin{array}{c}\text { FINE } \\
\text { AGGREGATE }\end{array}$ & $\begin{array}{c}\text { AIR } \\
\text { ENTR }\end{array}$ & HRWRA & W/C \\
\hline \hline & $(\mathrm{Kg})$ & $(\mathrm{Kg})$ & $(\mathrm{Kg})$ & $(\mathrm{Kg})$ & $(\mathrm{Kg})$ & $(\mathrm{Kg})$ & $\mathrm{ml}$ & $\mathrm{ml}$ & \\
\hline S1 & 251 & 115 & 18 & 154 & 1038 & 699 & 1471 & 3187 & 0.4 \\
\hline S2 & 232 & 134 & 18 & 154 & 1038 & 696 & 1354 & 4072 & 0.4 \\
\hline S3 & 270 & 96 & 18 & 154 & 1038 & 711 & 1471 & 3748 & 0.4 \\
\hline
\end{tabular}

Note: All values are based on one cubic meter of concrete. $\mathrm{Cm}=$ cementitious material=Cement + fly ash or slag+ silica fume 


\subsection{Mixing Procedure}

All mixing was done in a standard laboratory rotary drum mixer. Figure 3.6 shows the type of mixer used in this study. The moisture content of the fine aggregate was determined just prior to the mixing to obtain the correct value of surface moisture and to adjust the mixing water accordingly to maintain the effective water-cementitious ratio as 0.40 . The coarse aggregate was assumed to be in a state of saturated surface dry condition.

The mixing sequence was as follows:

1. Approximately one third of water was added.

2. All the coarse aggregate and fine aggregate were added. The mixer was rotated until the aggregates were well mixed.

3. All cementitious materials such as cement, fly ash or slag, silica fume and remaining mixing water were added and mixed well for about five minutes or until the mixture was uniform.

4. HRWRA and AEA were added while the mixer was kept rotating for another 8 to 10 minutes or until the mixture was uniform. The HRWRA dosage was controlled to obtain the desired slump.

As soon as the mixing was complete, slump, temperature, air content and unit weight of concrete were measured according with relevant ASTM and AASHTO standards. 


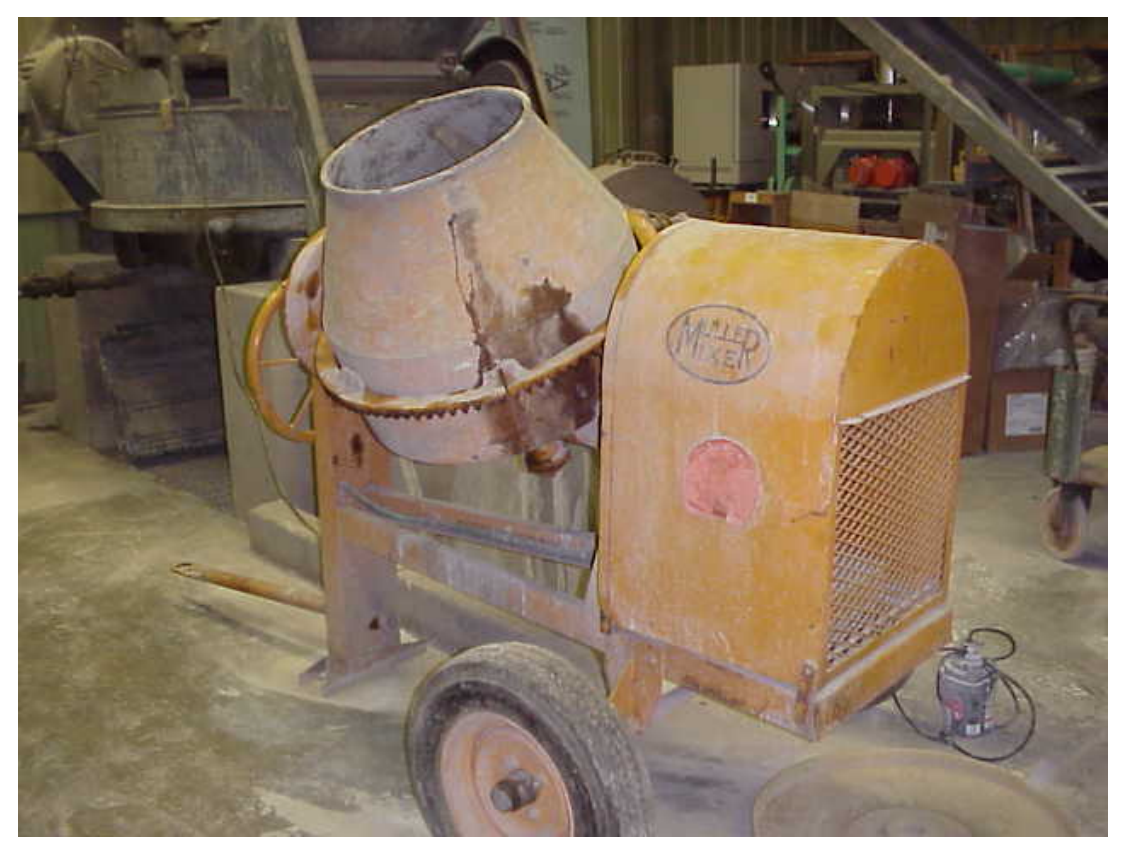

Figure 3.6 Drum Mixer of 3-cubic Feet Capacity

\subsection{Preparations of Test Specimens}

\subsubsection{Cylinder Specimens for Compressive Strength}

Twenty-three cylinder specimens of 4 in. dia. $x 8$ in. long (101.6 mm x $203.2 \mathrm{~mm})$ cylinder specimens were casted in two batches for each mixture using plastic molds. Twenty one of them were used for compressive strength tests at different ages and the other two were used for rapid chloride permeability tests. Figures 3.7 and 3.8 show the test specimens. The cylinders were casted in accordance with ASTM C 192 (Standard Practice for Making and Curing Concrete Test Specimens in the Laboratory). Within few minutes after casting, the specimens were covered with a plastic sheet and left to cure at room temperature in the laboratory for 24 hours. The specimens were then demolded and subjected to the specified curing condition as described later in section 3.4.5. 


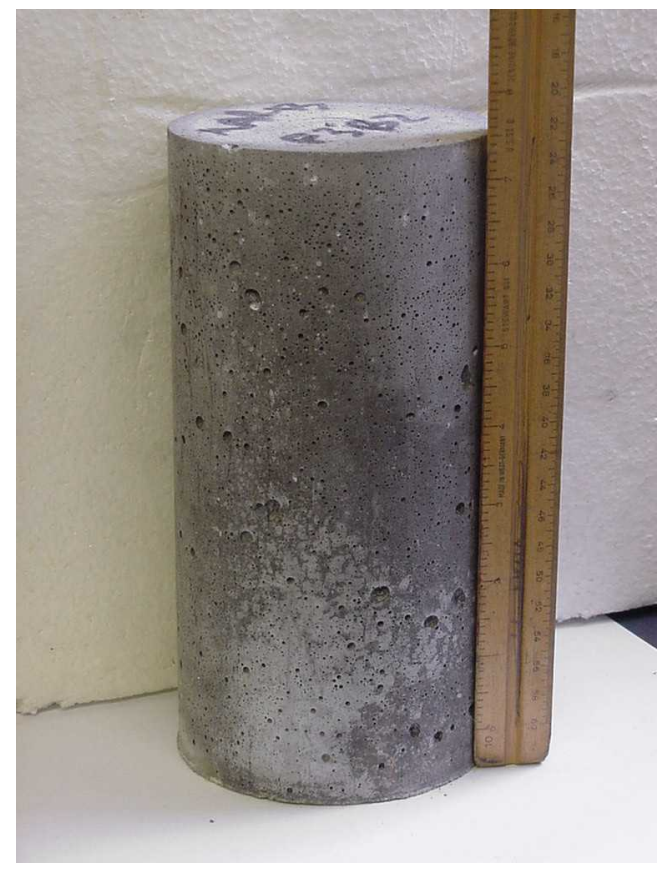

Figure $3.7 \quad$ Compressive Strength Test Specimen (4 in. dia. $x 8$ in. high)

\subsubsection{Beam Specimens for Length Change Measurement (Shrinkage)}

Three 3 in. $\times 3$ in. $\times 10$ in. long (76.2 $\mathrm{mm} \times 7.2 \mathrm{~mm} \times 254 \mathrm{~mm}$ long) beam specimens (Figure 3.8) were casted in two batches (two from batch 1, the other one from batch 2) using steel molds. The dimensions of the beam specimen were according to ASTM C 157 (Standard Test Method for Length Change of Hardened Hydraulic-Cement Mortar and Concrete). After casting, the specimens were covered with a plastic sheet. After 24 hours, the demolded specimens were subjected to the specified curing condition as described in section 3.4.5. 


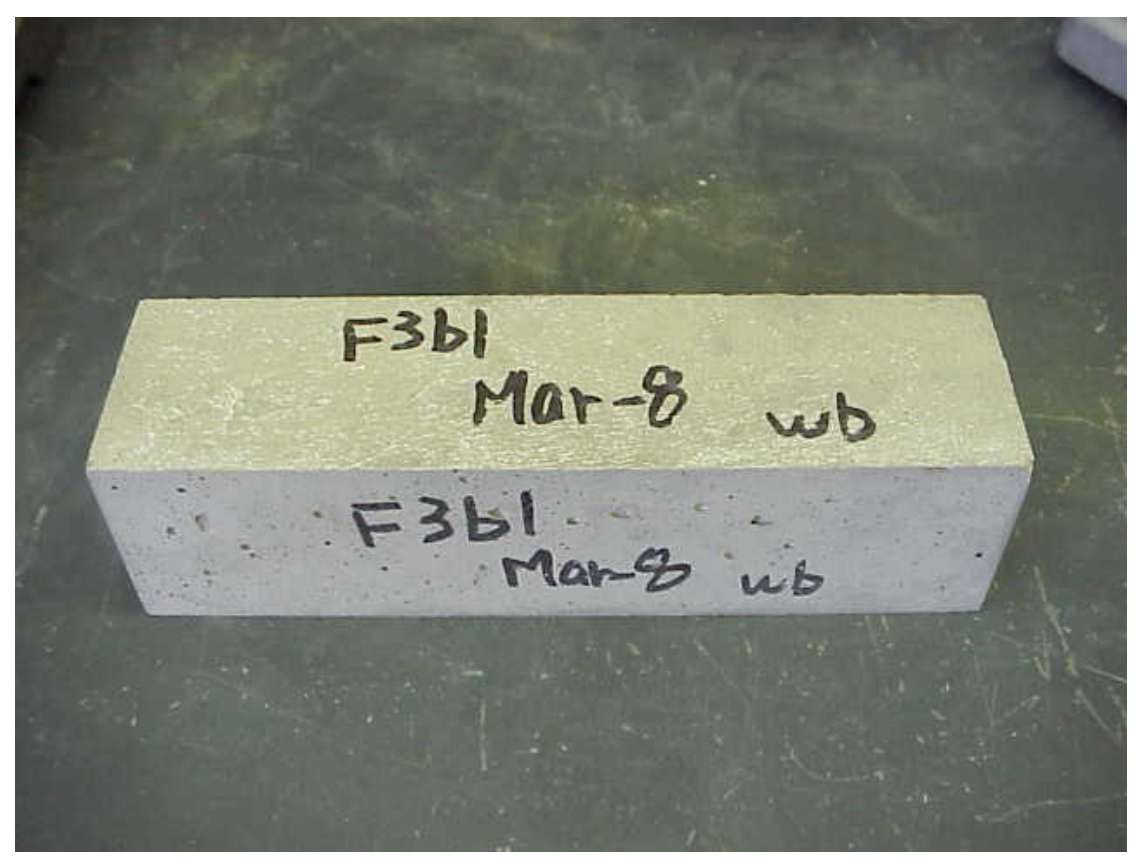

Figure 3.8 Shrinkage Beam Specimen

( 3 in. $x 3$ in. $x 10$ in.)

\subsubsection{Beam Specimens for Freeze/Thaw Durability Test}

Two 3 in. $x 4$ in. $x 16$ in. long (76.2 mm x $101.6 \mathrm{~mm} \mathrm{x} 406.4 \mathrm{~mm}$ long) beam specimens (Figure 3.9) were casted in two batches for each mixture by using steel molds. The dimensions of the beam specimen were in accordance with ASTM C 666 (Standard Test Method for Resistance of Concrete to Rapid Freezing and Thawing). Soon after casting, the specimens were covered with a plastic sheet. After 24 hours, the demolded specimens were subjected to the specified curing condition as given in section 3.4.5. 


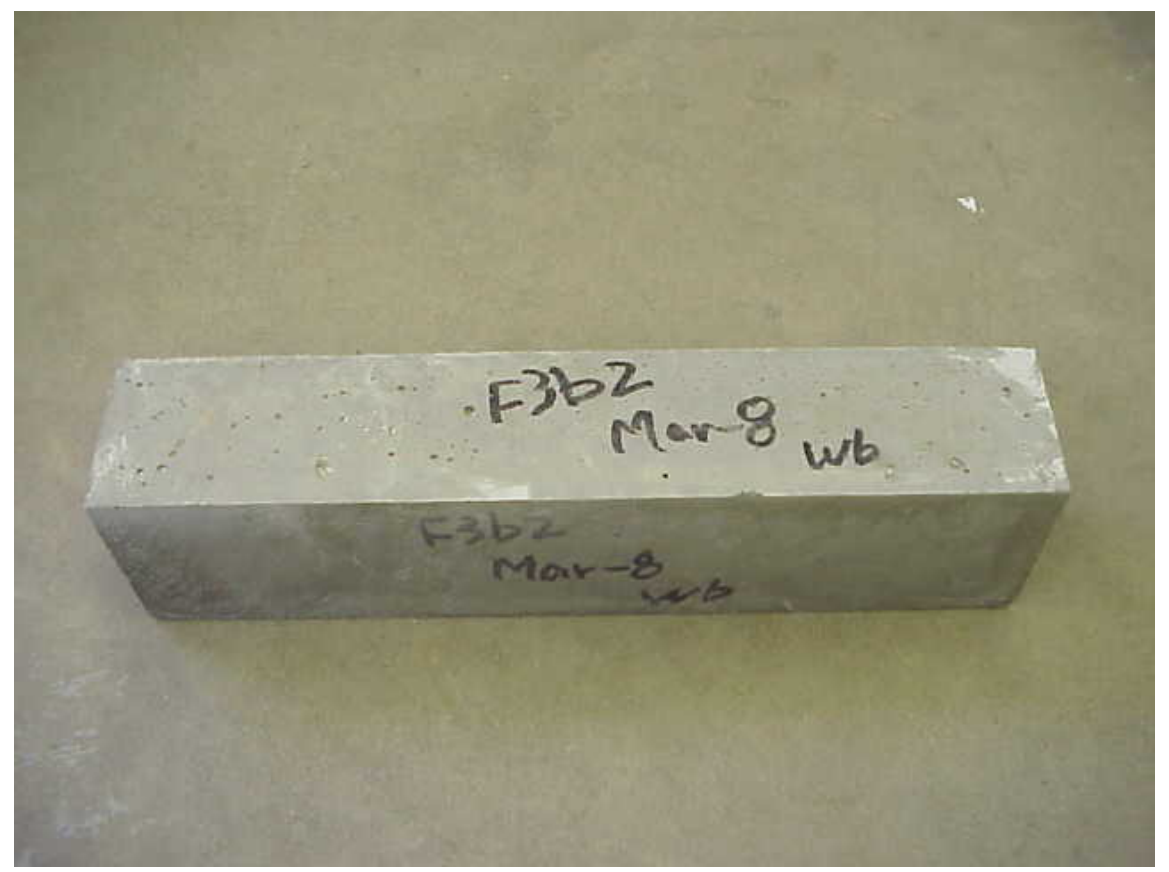

Figure $3.9 \quad$ Freeze-Thaw Beam Specimen

(3in. $x 4$ in. $x 16$ in.)

\subsubsection{Disk Specimen for Rapid Chloride Permeability Test}

For each mixture, two disks of 4 inch diameter $\mathrm{x} 2$ inch thickness were cut from the top portions of the cylinder specimens for chloride permeability tests. The top portion of the cylinder was selected to simulate the exposed section of a concrete bridge deck, which is normally subjected to de-icing salts. Two disks for each mixture were cut by taking one sample from each batch. The diameter of the disk specimen was in accordance with ASTM C 1202 (Electrical Indication of Concrete's Ability to Resist Chloride Ion Penetration). 


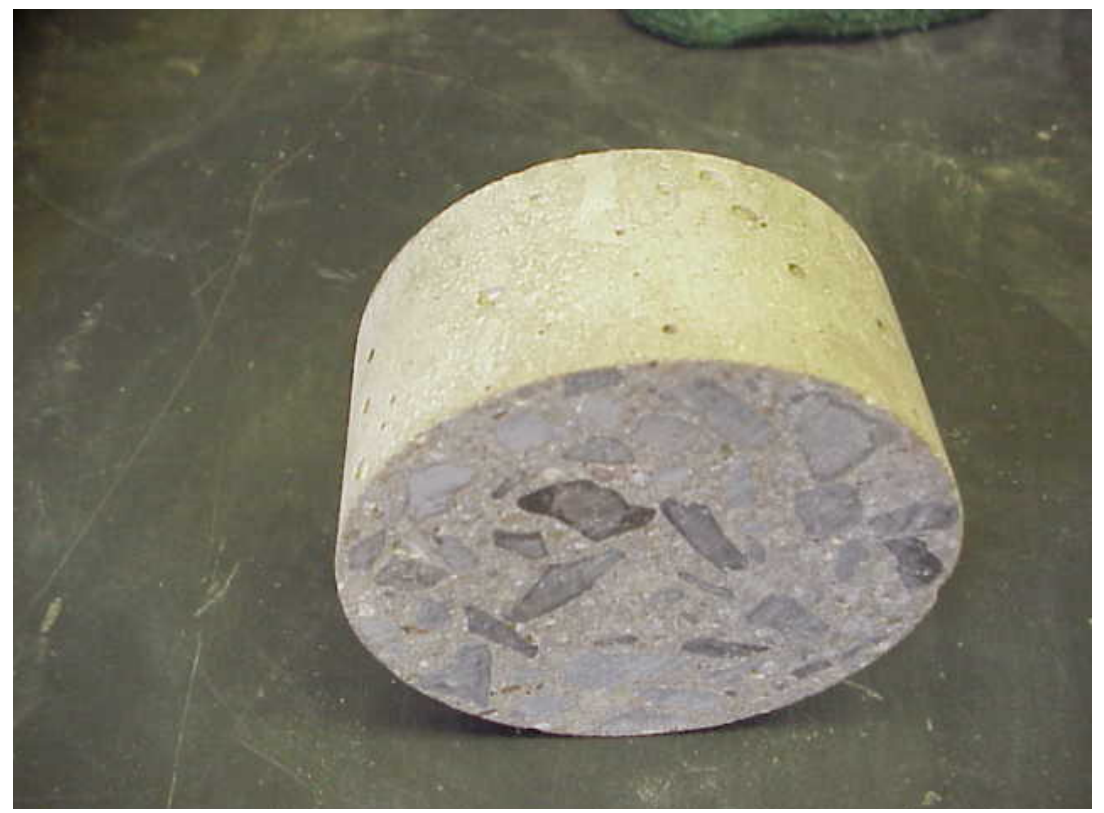

Figure 3.10

Rapid Chloride Permeability Test Specimen

( 2 in. thickness $\times 4$ in. diameter)

\subsubsection{Curing of Different Types of Test Specimens}

Twenty-four hours after casting, all of the specimens were removed from the molds, and the cylinder specimens were placed under wet burlaps in a curing room at $73^{\circ} \mathrm{F}$ until the day of testing. The wet burlap ensured the relative humidity to be about 100 percent.

The freeze-thaw test specimens were cured under limewater for 14 days at $73^{\circ} \mathrm{F}$ and then subjected to the rapid freezing-thawing cycles. Specimens for measurement of length change (shrinkage) were cured under limewater for 7 days at $73^{\circ} \mathrm{F}$ and then stored in a curing room at a temperature of $73^{\circ} \mathrm{F} \pm 3^{\circ} \mathrm{F}$ and a humidity of about $50 \% \pm 4 \%$. The length-change (shrinkage) specimens were stored in such a way as to allow as much air circulation around the surfaces of the specimen as possible. 


\subsection{Testing Procedures}

\subsubsection{Testing on Fresh Concrete}

These tests include slump, air content, unit weight and temperature.

\subsubsection{Slump Test}

The slump of fresh concrete was measured in accordance with ASTM C 143 (Standard Test Method for Slump of Hydraulic Cement Concrete) and AASHTO T 119. Soon after the mixing was completed, the quality of mixture was also noticed visually.

Figure 3.11 shows the test apparatus.

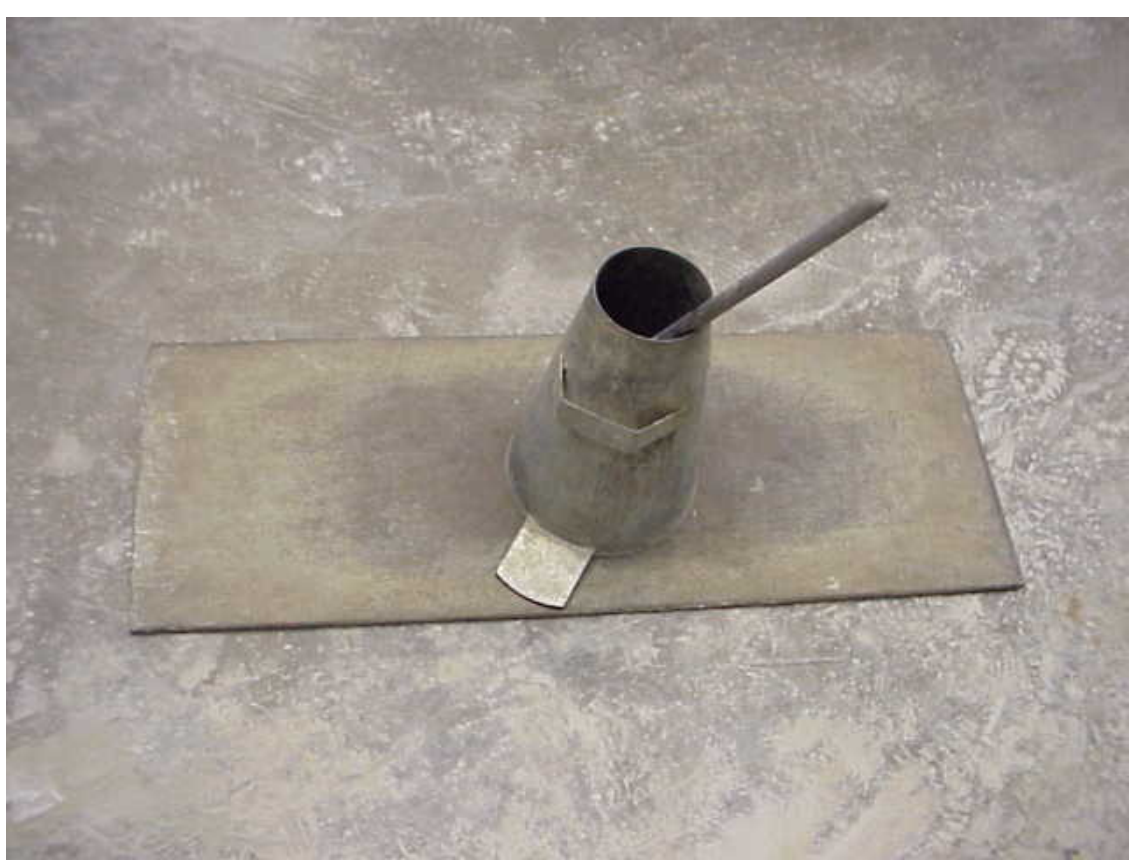

Figure 3.11 Metal cone to Measure Slump 


\subsubsection{Air Content}

The air content of fresh concrete was determined by the pressure method in accordance with ASTM C 231 (Standard Test Method for Air Content of Freshly Mixed Concrete by the Pressure Method) and AASHTO T 152 . Figure 3.12 shows the test apparatus.

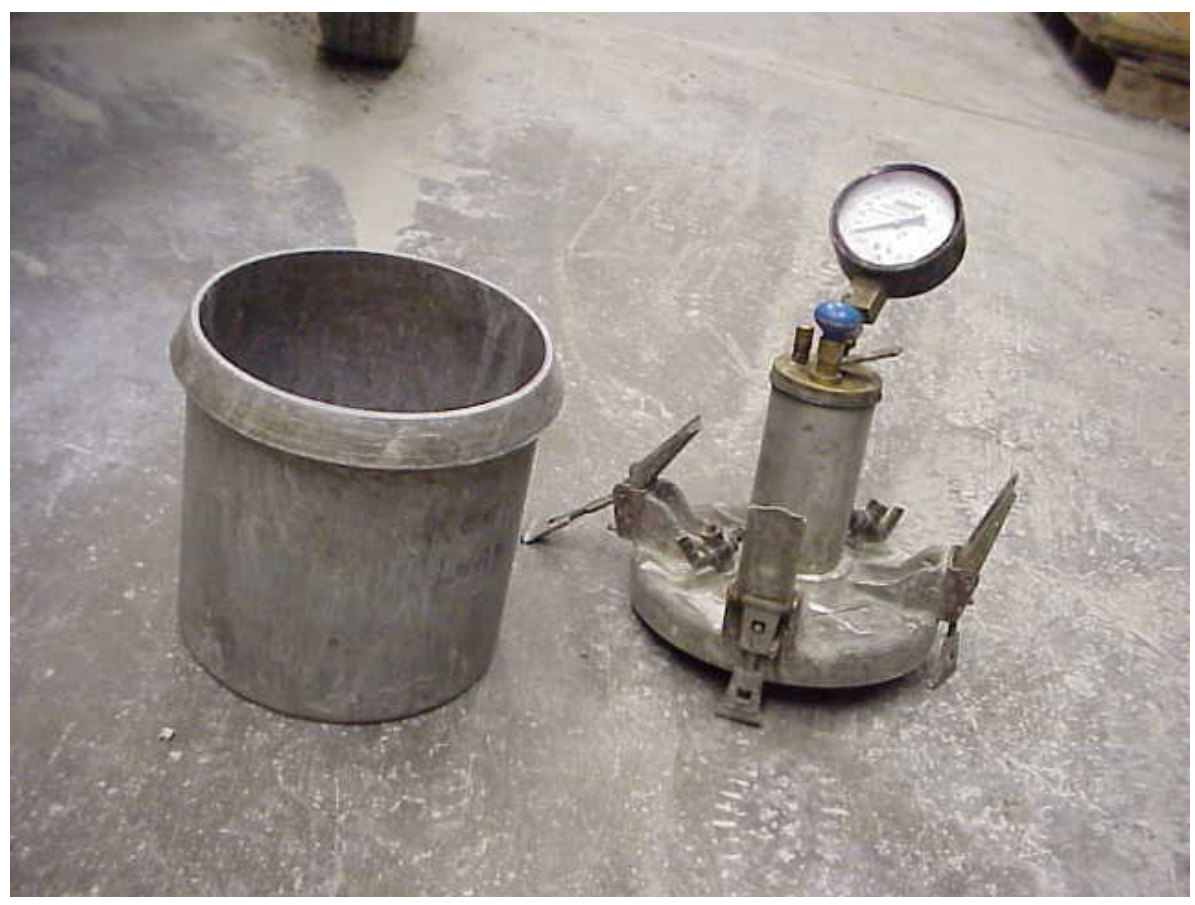

Figure 3.12 Apparatus Used to Measure the Air Content in the Concrete

\subsubsection{Unit Weight}

The unit weight of fresh concrete was measured per ASTM C 138 (Standard Test Method for Unit Weight, Yield, and Air Content of Concrete) and AASHTO T 121.

\subsubsection{Temperature}

The temperature of concrete was measured with a standard thermometer, with an accuracy of $\pm 0.5^{\circ} \mathrm{F}$, soon after mixing was completed, in accordance with ASTM C 
1064 (Standard Test Method for Temperature of Freshly Mixed Portland Cement Concrete).

\subsubsection{Testing of Hardened Concrete}

These tests include compressive strength, shrinkage, freeze-thaw, and rapid chloride permeability.

\subsubsection{Compressive Strength}

Compressive strength of cylinder specimens was measured in accordance with ASTM C 39 (Standard Test Method for Compressive Strength of Cylindrical Concrete Specimens) and AASHTO T 22 using 350,000 lbs capacity hydraulic type compression machine. Tests were conducted on specimens at 1, 3, 7, 14, 28, 56, and 90 days. For each mixture three specimens were tested taking two from batch 1 and one from batch 2 . Figure 3.13 shows the testing machine with specimen. Figure 3.14 shows the specimen after typical compression failure.

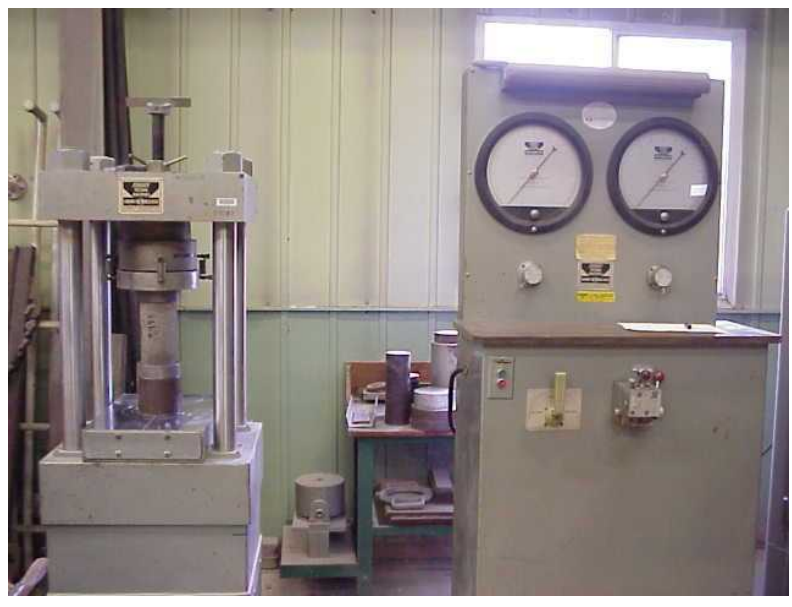

Figure 3.13 Compressive Strength Test Machine 


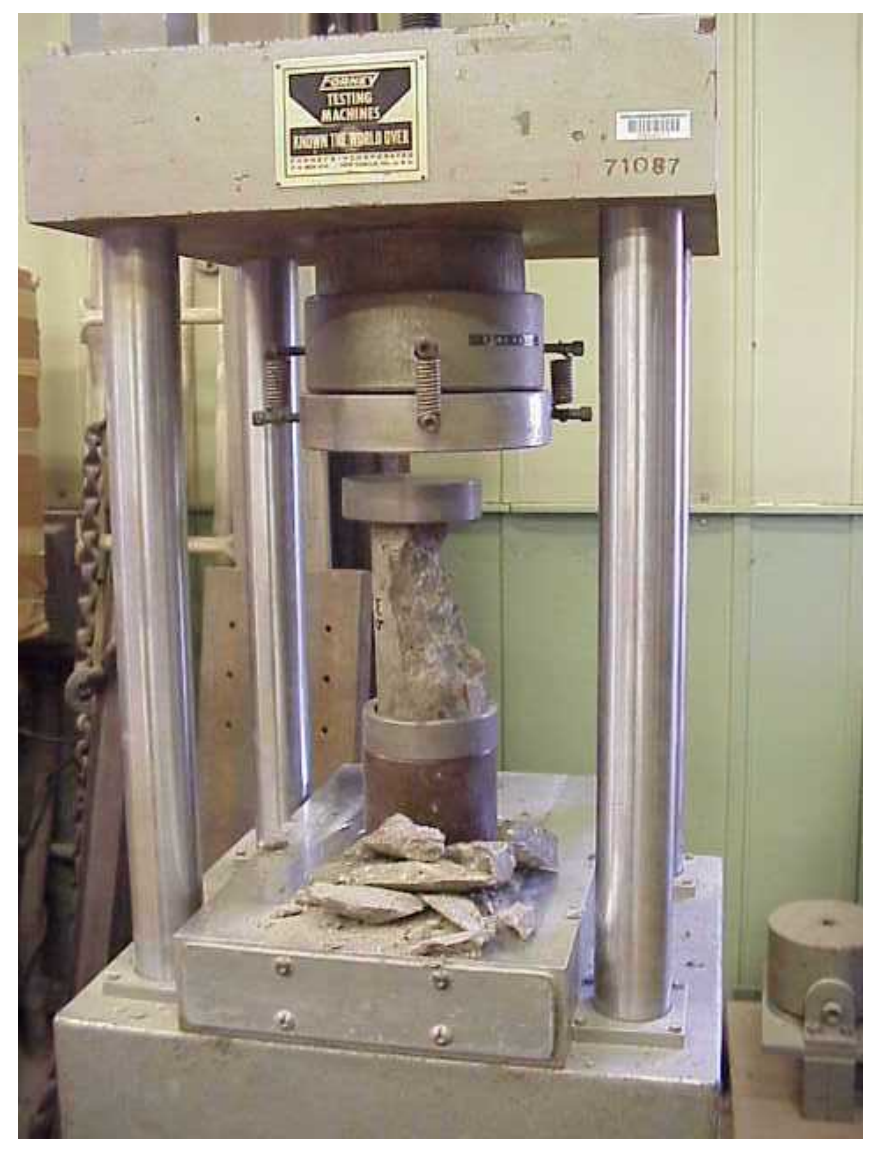

Figure 3.14 Specimen After Shear Failure

\subsubsection{Length Change Measurement (Shrinkage) Test}

The length change of concrete specimens was measured in accordance with ASTM C 157 (Standard Test Method for Length Change of Hardened Hydraulic-Cement Mortar and Concrete) and AASHTO T 160. For each mixture, three specimens were tested, taking two from batch one and one from batch two. The readings were taken by a standard length change comparator at 4, 7, 14, 21, 28, 35, 42, 49 and 56 days, after curing of specimens for 7 days as mentioned before in 3.4.5. Figure 3.15 shows a lengthchange test in progress. 


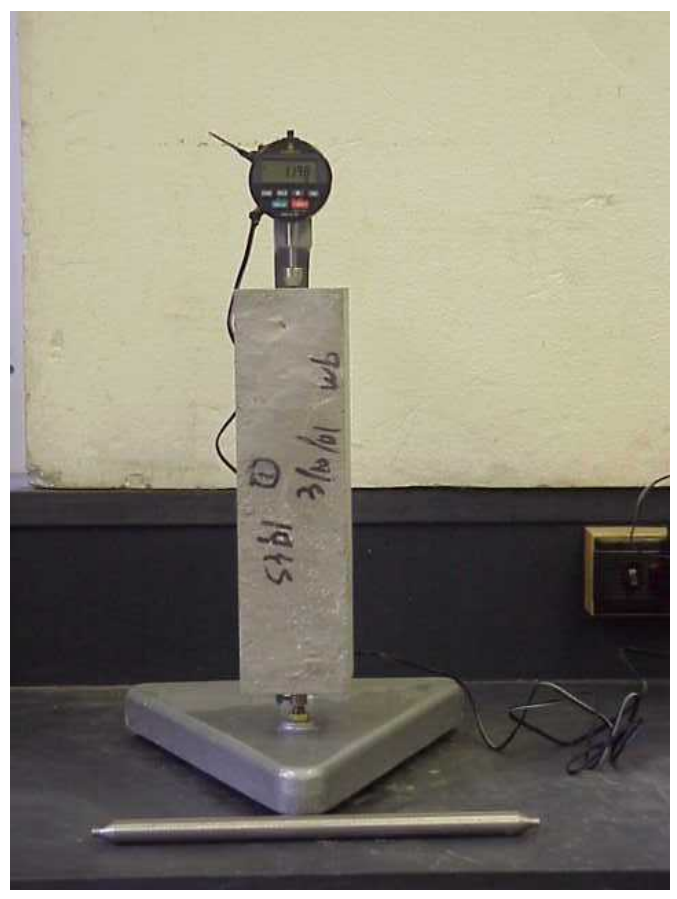

Figure 3.15 Length Change Measurement in Progress

\subsubsection{Freeze/thaw Durability Test}

The freeze-thaw test was conducted in accordance with ASTM C 666 (Standard Test Method for Resistance of Concrete to Rapid Freezing and Thawing) and AASHTO $\mathrm{T}$ 161. After removing the specimen from the lime saturated water, they were wiped with damp towels, and then, measurements of length, mass and fundamental frequency were taken before they were subjected to freeze-thaw cycles. The length, mass and fundamental frequency values were noted after each 50 cycles. The fundamental transverse frequency was determined to measure the change in dynamic modulus of elasticity of concrete after each 50 cycles, and the procedure used followed the ASTM C 215 standard. Each cycle of freezing-thawing was maintained as follows: the temperature was lowered to $0^{\circ} \mathrm{F}$ from $40^{\circ} \mathrm{F}$ in a time period of 2 hours and then raised to $40^{\circ} \mathrm{F}$ also within 2 hours. The entire procedure is planned to continue for a total of 300 cycles or 
until there is visible and noticeable deterioration. Due to the slow ratio of freeze-thaw cycles (about 6 cycles a day), the maximum cycles of 300 was not reached for specimen S1. The present thesis, therefore, reports the durability factor of all the mixtures except fro S1. However we report the resonant frequency values for S1 up to 250 cycles. Figure 3.16 shows the freeze-thaw testing chamber with the specimens. Figures $3.17 \mathrm{a}$ and $3.17 \mathrm{~b}$ show the fundamental transverse frequency test in progress.

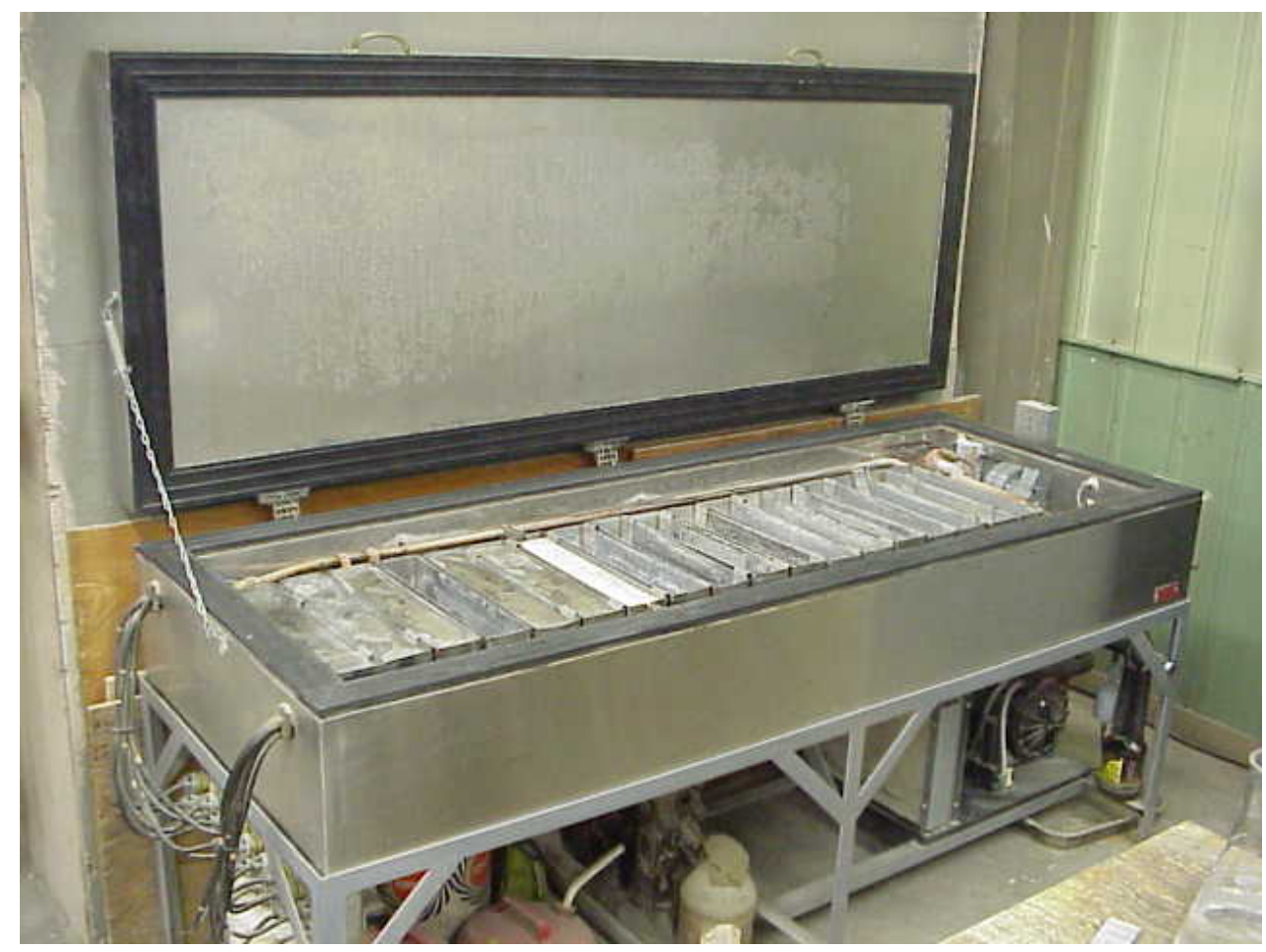

Figure 3.16 Freeze/Thaw Testing Chamber with Specimens 


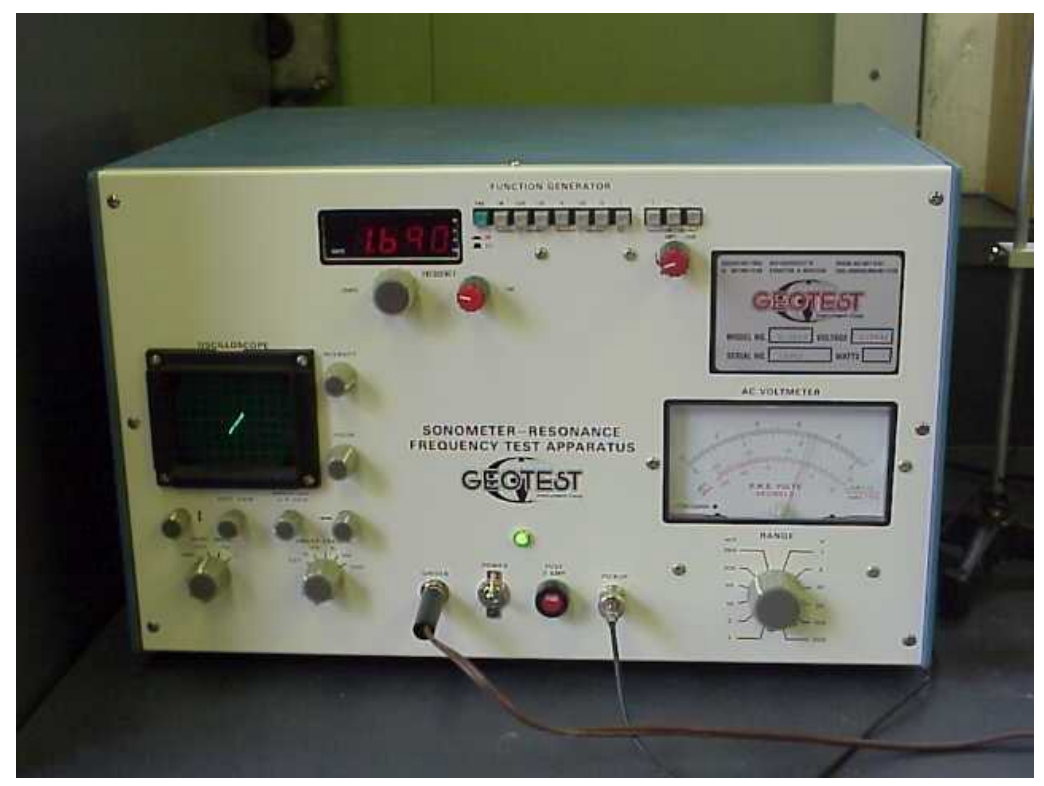

Figure 3.17a Sonometer (Resonance Frequency Test Apparatus)

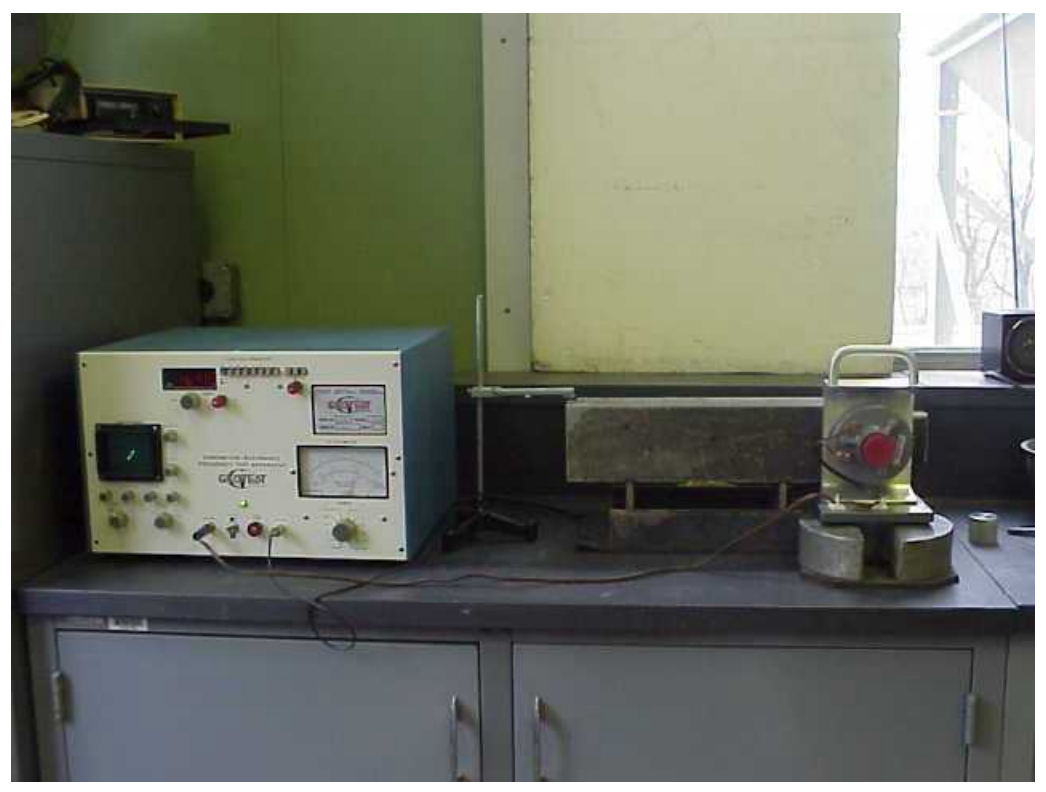

Figure 3.17b Fundamental Transverse Frequency Test in Progress 


\subsubsection{Rapid Chloride Permeability Test}

The chloride permeability test of disc specimens cut from cylinders was conducted in accordance with ASTM C 1202 (Standard Test Method for Electrical Indication of Concrete's Ability to Resist Chloride Ion Penetration) and AASHTO T 277. Figure 3.18a shows the apparatus. The circular surfaces of the disc specimens were coated with an epoxy sealant. The specimen was then brought to a standard moisture condition by the following vacuum saturation procedure: Vacuum was applied to the dry specimen for 3 hours, and then continued for 1 more hour with the specimen immersed in de-aerated water. After then the specimen was soaked in the same water for an additional $18 \pm 2$ hours at atmospheric pressure. The ends of the specimen were then sealed into hollow, polymethyl methacrylate (Plexiglas) chambers. The side of the cell containing the top of the sample was filled with a 3\% sodium chloride solution, and the other side containing the bottom with a $0.3 \mathrm{~N}$ sodium hydroxide solution. An electric current of sixty volts DC was applied across the specimen between copper screen electrodes contained in each cell. The total charge passed, or the integral of the current with respect to time, during a 6 hours period is a measure of the chloride permeability of the concrete. The test was conducted on properly cured 35 to 42 days old specimen. For each mixture, two specimens were tested, taking one from each batch. Figures $3.18 \mathrm{~b}$ and $3.18 \mathrm{c}$ show the test in progress. 


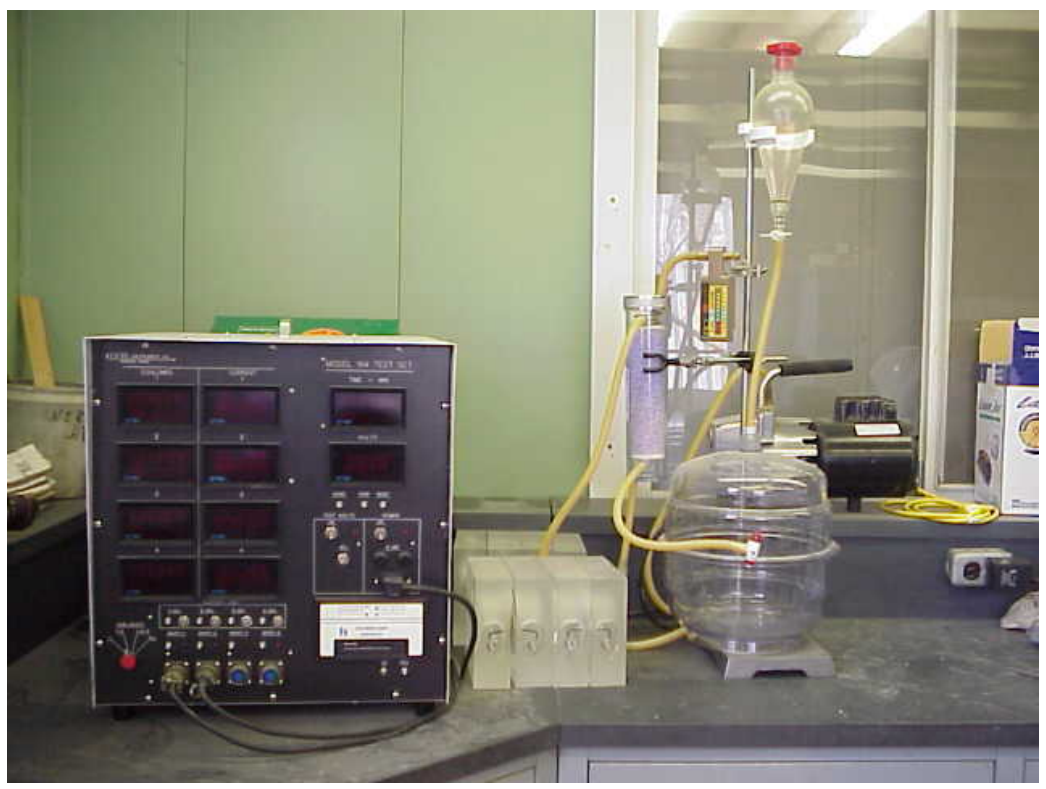

Figure 3.18a Vacuum System and Charge-Passed Measurement Apparatus

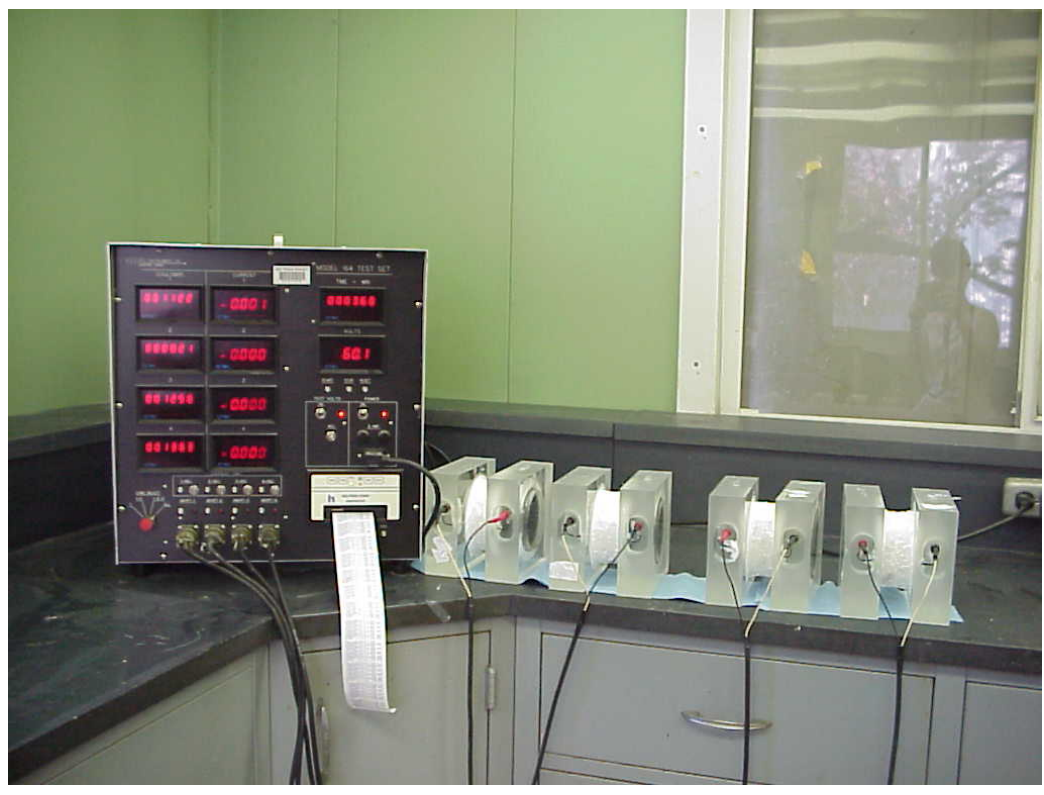

Figure 3.18b Chloride Permeability Test in Progress 


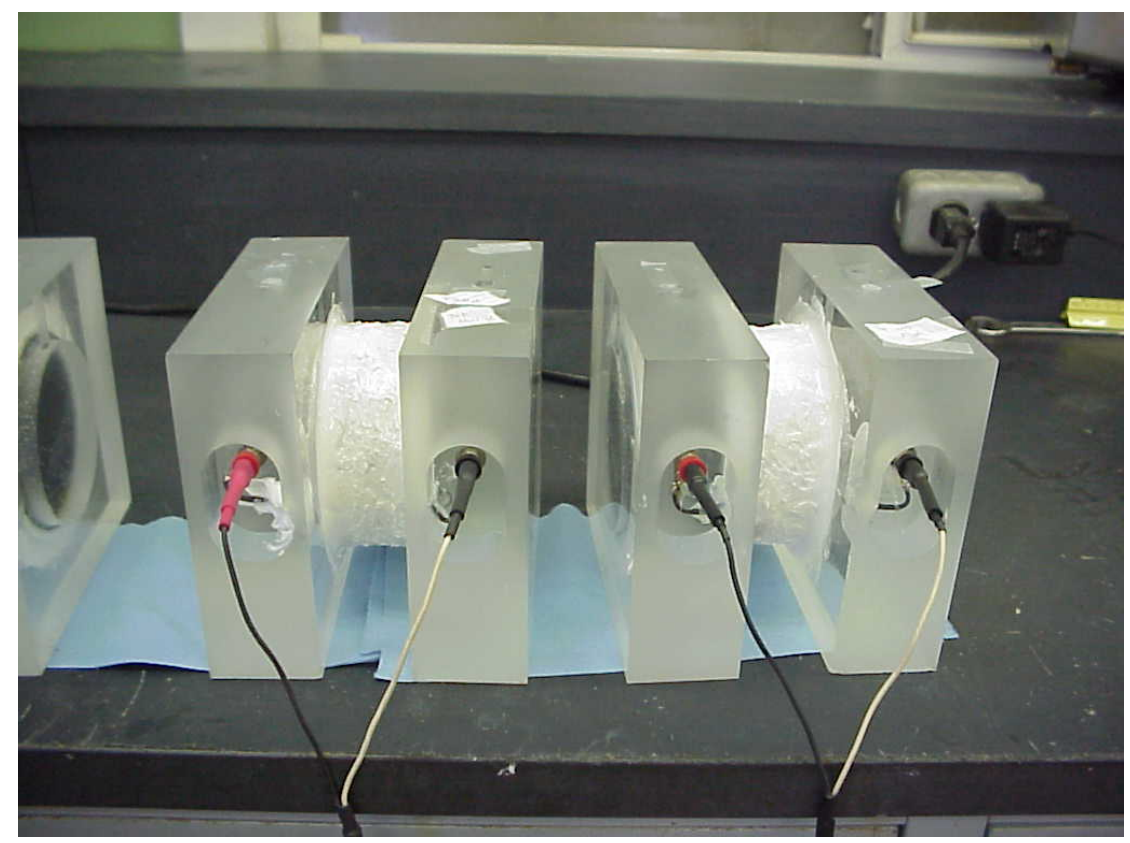

Figure 3.18c Close View of Chloride Permeability Test Specimens 


\section{Chapter 4}

\section{Test Results and Discussions}

This chapter presents the test results and discussions for fresh and hardened concrete. The results are presented in tables and figures. The fresh concrete properties include slump, air content, unit weight, temperature, and mix characteristics. The hardened concrete properties include compressive strength at different ages, drying shrinkage, freeze-thaw durability, and chloride permeability.

\subsection{Fresh Concrete Properties}

Each mixture of fresh concrete was tested according to the following standard methods: ASTM C143, Slump of Hydraulic Cement Concrete; ASTM C138, Unit Weight and Air Content; ASTM C231, Air Content of Freshly Mixed Concrete by Pressure Method; ASTM C1064, Temperature of Freshly Mixed Portland Cement Concrete, and their corresponding AASHTO standards.

Table 4.1 and Table 4.2 show the mixture proportioning of HPC for the fly ash group (Group F) and slag group (Group S), respectively. Table 4.3 and Table 4.4 list the fresh properties of HPC for the fly ash group (Group F) and slag group (Group S), respectively. 
Table 4.1. Mixture Proportioning of HPC of Fly Ash Group (Group F)

\begin{tabular}{|c|c|c|c|c|c|c|c|}
\hline $\begin{array}{l}\text { Mixture } \\
\text { Type }\end{array}$ & $\begin{array}{l}\text { Cement } \\
\left(\mathrm{Ib} / \mathrm{yd}^{3}\right)\end{array}$ & $\begin{array}{l}\text { Fly ash } \\
\left({\left.\mathrm{lb} / \mathrm{yd} \mathrm{d}^{3}\right)}\right.\end{array}$ & $\begin{array}{c}\text { Fine Aggr. } \\
\left(\mid \mathrm{lb} / \mathrm{yd}^{3}\right)\end{array}$ & $\begin{array}{c}\text { AEA } \\
\left(\mathrm{oz} / \mathrm{yd}^{3}\right)\end{array}$ & $\begin{array}{l}\text { HRWRA } \\
\left(\mathrm{oz} . / \mathrm{yd}^{3}\right)\end{array}$ & $\begin{array}{l}\text { W/Cm } \\
\text { ratio }\end{array}$ & $\begin{array}{l}\text { C/FA/SF } \\
\text { ratio by } \\
\text { weight }\end{array}$ \\
\hline F1(current DOH) & 470 & 124 & 1206 & 18 & 100 & 0.40 & $75 / 20 / 5$ \\
\hline F2 & 438 & 156 & 1221 & 20 & 75 & 0.40 & $70 / 25 / 5$ \\
\hline F3 & 500 & 94 & 1214 & 20 & 108 & 0.40 & $80 / 15 / 5$ \\
\hline
\end{tabular}

Note: $\quad$ For all mixtures, Coarse aggregate (Limestone) $=1750 \mathrm{lb} / \mathrm{yd}^{3}$, silica fume $(\mathrm{SF})=30 \mathrm{lb} / \mathrm{yd}^{3}$, Water $=250 \mathrm{lb} / \mathrm{yd}^{3}$, Cementitious material $(\mathrm{Cm})=624 \mathrm{lb} / \mathrm{yd}^{3}, \mathrm{Cm}=\mathrm{C}+\mathrm{FA}+\mathrm{SF}$.

Table 4.2. Mixture Proportioning of HPC of Slag Group (Group S)

\begin{tabular}{|c|c|c|c|c|c|c|c|}
\hline $\begin{array}{c}\text { Mixture } \\
\text { Type }\end{array}$ & $\begin{array}{c}\text { Cement } \\
\text { (lb/yd3) }\end{array}$ & $\begin{array}{c}\text { Slag } \\
(\mathrm{lb} / \mathrm{yd} 3)\end{array}$ & $\begin{array}{c}\text { Fine Aggr. } \\
\left(\mathrm{lb} / \mathrm{yd}^{3}\right)\end{array}$ & $\begin{array}{c}\text { AEA } \\
\text { (oz./yd3) }\end{array}$ & $\begin{array}{c}\text { HRWRA } \\
\text { (oz./yd3) }\end{array}$ & $\begin{array}{c}\text { W/Cm } \\
\text { ratio }\end{array}$ & $\begin{array}{c}\text { C/SG/SF } \\
\text { ratio by } \\
\text { weight }\end{array}$ \\
\hline S1(current DOH) & 423 & 194 & 1178 & 38 & 82 & 0.40 & $65 / 30 / 5$ \\
\hline S2 & 391 & 226 & 1174 & 35 & 105 & 0.40 & $60 / 35 / 5$ \\
\hline S3 & 455 & 162 & 1198 & 38 & 97 & 0.40 & $70 / 25 / 5$ \\
\hline
\end{tabular}

Note: $\quad$ For all mixtures, Coarse aggregate (Limestone) $=1750 \mathrm{lb} / \mathrm{yd}^{3}$, silica fume $(\mathrm{SF})=30 \mathrm{lb} / \mathrm{yd} 3$, Water $=259 \mathrm{lb} / \mathrm{yd} 3$, Cementitious materials $=647 \mathrm{lb} / \mathrm{yd} 3, \mathrm{Cm}=\mathrm{C}+\mathrm{SG}+\mathrm{SF}$.

Table 4.3. Characteristics of Freshly Mixed HPC of Fly Ash Group (Group F)

\begin{tabular}{||c|c|c|c|c|c|c|c||}
\hline \multirow{2}{*}{ MIXTURE } & AIR CONTENT & \multicolumn{2}{|c|}{ SLUMP } & \multicolumn{2}{c|}{ UNIT WEIGHT } & \multicolumn{2}{c||}{ TEMPERATURE } \\
\cline { 2 - 8 } & $(\%)$ & $(\mathrm{mm})$ & $(\mathrm{inch})$ & $\left(\mathrm{kg} / \mathrm{m}^{3}\right)$ & $(\mathrm{pcf})$ & $\left({ }^{\circ} \mathrm{C}\right)$ & $\left({ }^{\circ} \mathrm{F}\right)$ \\
\hline \hline $\begin{array}{c}\text { F1 } \\
(\text { Current DOH) }\end{array}$ & 6.0 & 175 & 7.0 & 2387 & 149 & 17.2 & 63 \\
\hline $\begin{array}{c}\text { F2 } \\
(\text { More FA) }\end{array}$ & 5.0 & 140 & 5.5 & 2371 & 148 & 17.8 & 64 \\
\hline $\begin{array}{c}\text { F3 } \\
\text { (Less FA) }\end{array}$ & 7.0 & 150 & 6.0 & 2323 & 145 & 16.7 & 62 \\
\hline \hline
\end{tabular}


Table 4.4. Characteristics of Freshly Mixed HPC of Slag Group (Group S)

\begin{tabular}{||c|c|c|c|c|c|c|c||}
\hline \multirow{2}{*}{ MIXTURE } & AIR CONTENT & \multicolumn{2}{|c|}{ SLUMP } & \multicolumn{2}{c|}{ UNIT WEIGHT } & \multicolumn{2}{|c|}{ TEMPERATURE } \\
\cline { 2 - 8 } & $(\%)$ & $(\mathrm{mm})$ & $($ inch $)$ & $\left(\mathrm{kg} / \mathrm{m}^{3}\right)$ & $(\mathrm{pcf})$ & $\left({ }^{\circ} \mathrm{C}\right)$ & $\left({ }^{\circ} \mathrm{F}\right)$ \\
\hline \hline $\begin{array}{c}\text { S1 } \\
(\text { Current DOH) }\end{array}$ & 6.0 & 165 & 6.5 & 2371 & 148 & 18.3 & 65 \\
\hline $\begin{array}{c}\text { S2 } \\
(\text { More SG) }\end{array}$ & 5.2 & 180 & 7.0 & 2371 & 148 & 15.6 & 60 \\
\hline $\begin{array}{c}\text { S3 } \\
\text { (Less SG) }\end{array}$ & 7.0 & 180 & 7.0 & 2291 & 143 & 18.3 & 65 \\
\hline \hline
\end{tabular}

Table 4.3 shows that values of both air content (5.0\% to $7.0 \%)$ and slump (5.5 to 7 inches) of the Group F HPC were within the range of the WVDOH requirements for Class $\mathrm{H}$ concrete. Table 4.1 indicates that the demand for HRWRA decreases as the fly ash content increases, while slump is within a range of 5.5 to 7 inches, and the $\mathrm{W} / \mathrm{Cm}$ ratio and cement factor are constant. Though the F2 mixture shows a relatively low slump value of 5.5 inches, it could have been improved by a little addition of HRWRA. Table 4.3 further shows that the unit weight of the current WVDOH Class $\mathrm{H}$ concrete was the maximum for the Group F, though all of the mixtures are within a narrow range of normal unit weight of 145 pcf to 149 pcf. The temperature of the concrete just before placement was also within a reasonable range of $62^{\circ} \mathrm{F}$ to $64^{\circ} \mathrm{F}$. Increasing or decreasing the fly ash content by $\pm 5 \%$ (by weight) over the current WVDOH mixture did not influence the fresh properties much.

Table 4.4 shows that values of both air content (5.2\% to $7.0 \%)$, and slump (6.5 to 7.0 inches) of the Group S HPC were within the range of the WVDOH requirements for Class H concrete. Table 4.2 indicates that the demand for HRWRA was maximum for the HPC with slag content of $35 \%$, while the current WVDOH Class H concrete needed the minimum quantity of HRWRA to achieve a slump range of 6.5 to 7.0 inches, and 
constant $\mathrm{W} / \mathrm{Cm}$ ratio and cement factor. Table 4.4 indicates that the variation of slag by $\pm 5 \%$ from the current $\mathrm{WVDOH}$ mixture did not influence the fresh properties much. The temperature of the concrete just before placement was within $60^{\circ} \mathrm{F}$ to $65^{\circ} \mathrm{F}$. It is important to observe that the HPC for the Slag Group needed about 73\% to $110 \%$ more AEA than the HPC for the Fly ash Group to achieve almost the same range of air content. The S2 and S3 mixtures were more workable than the counterpart F2 and F3 mixtures.

In general, it was observed that increasing the fly ash or slag content over over current WVDOH mixture made the concrete more cohesive and free from any segregation and bleeding, even under vibration with a needle vibrator. While decreasing the fly ash or slag content over the corresponding WVDOH mixtures made the mixtures susceptible to bleeding and segregation to some extent during vibration.

\subsection{Compressive Strength}

The compressive strength test was performed according to the standard method ASTM C39, Compressive Strength of Cylindrical Concrete and AASHTO T 22. The compressive strength was measured at ages of $1,3,7,14,28,56$, and 90 days, and the values for the individual specimen, along with the mean and the variations from the mean values are given in Appendix A (Tables A.1 through A.6).

Table 4.5 and Table 4.6 present the average values of compressive strengths for the Group F and Group S concrete, respectively. The variations of compressive strength among the specimens for each age were within the prescribed limit of ASTM C 39 . Figure 4.1 shows the best-fit compressive strength-age relationship for all HPC of the fly ash group, while figure 4.2 shows the same relationship for all HPC of the slag group. 
Table 4.5 Compressive Strength of Group F HPC at Different Ages

\begin{tabular}{|c|c|c|c|}
\hline \multirow{2}{*}{$\begin{array}{c}\text { Time } \\
(\text { Days })\end{array}$} & F1 (current DOH) & F2 (5\% more FA) & F3 (5\% less FA) \\
\cline { 2 - 4 } & $(\mathrm{psi})$ & $(\mathrm{psi})$ & $(\mathrm{psi})$ \\
\hline 1 & 3640 & 3340 & 3420 \\
\hline 3 & 5190 & 5070 & 5410 \\
\hline 7 & 6530 & 5910 & 6420 \\
\hline 14 & 7520 & 6680 & 7270 \\
\hline 28 & 8500 & 8070 & 7740 \\
\hline 56 & 9140 & 8760 & 8450 \\
\hline 90 & 9630 & 9610 & 9200 \\
\hline
\end{tabular}

Table 4.6 Compressive Strength of Group S HPC at Different Ages

\begin{tabular}{|c|c|c|c|}
\hline \multirow{2}{*}{$\begin{array}{c}\text { Time } \\
(\text { Days })\end{array}$} & S1 (current DOH) & S2 (5\% more SG) & S3 (5\% less SG) \\
\cline { 2 - 4 } & $(\mathrm{psi})$ & $(\mathrm{psi})$ & $(\mathrm{psi})$ \\
\hline 1 & 2800 & 2290 & 2370 \\
\hline 3 & 4620 & 4230 & 4990 \\
\hline 7 & 6620 & 6140 & 6420 \\
\hline 14 & 7620 & 7170 & 7910 \\
\hline 28 & 9210 & 8730 & 8610 \\
\hline 56 & 9940 & 9120 & 9380 \\
\hline 90 & 11170 & 9650 & 10030 \\
\hline
\end{tabular}


The general form of the best-fit equation in Figs. 4.1 and 4.2 is

$$
F(t)=A-B e^{-m t^{n}}
$$

Where,

$\mathrm{t}-$ time in days, $1 \leq \mathrm{t} \leq 90$,

$\mathrm{F}(\mathrm{t})$ - compressive strength at time $\mathrm{t}$

The corresponding parameters for all six mixtures are furnished in Table 4.7. Figures 4.3 and Figure 4.4 show the comparison of 28-day compressive strengths for the Group F and Group S HPC mixtures, respectively. Figure 4.5 and Figure 4.6 show the comparison of 56-day compressive strengths for the Group F and group S mixtures, respectively.

Table 4.7 Parameters for Weibull Data Fit

\begin{tabular}{||c|c|c|c|c|c|c||}
\hline & $F 1$ & $F 2$ & $F 3$ & S1 & S2 & S3 \\
\hline \hline A & 10321 & 21936 & 11320 & 16031 & 9847 & 11605 \\
\hline B & 11798 & 31649 & 74182 & 27416 & 11784 & 56432 \\
\hline$m$ & 1.76 & 1.86 & 0.44 & 1.38 & 2.26 & 0.55 \\
\hline $\mathrm{n}$ & 0.35 & 0.12 & 0.10 & 0.19 & 0.48 & 0.15 \\
\hline $\mathrm{R}$ & 0.998 & 0.997 & 0.997 & 0.998 & 0.998 & 0.999 \\
\hline \hline
\end{tabular}




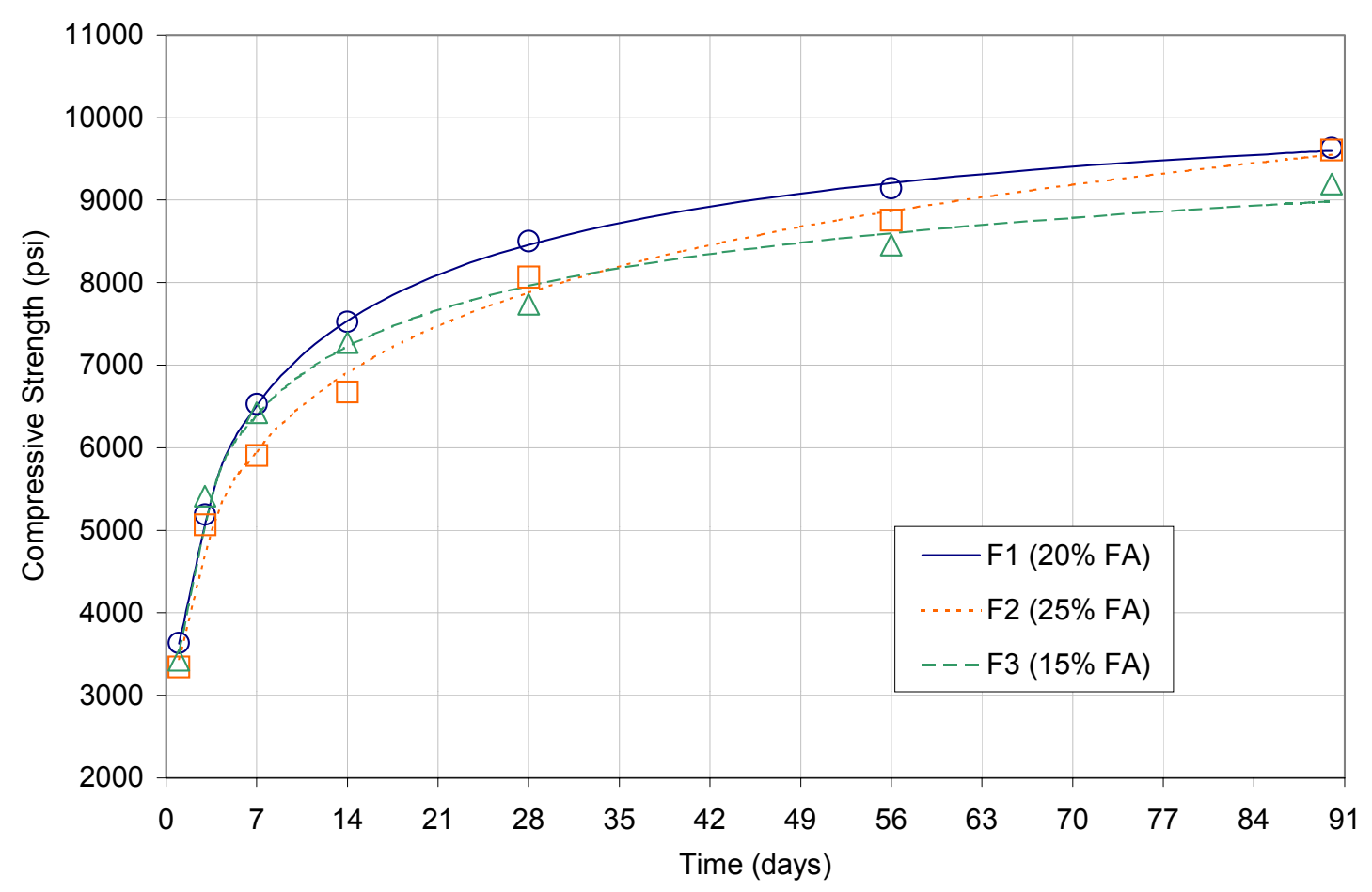

Figure 4.1 Compressive Strength - Age Relationship of Group F HPC

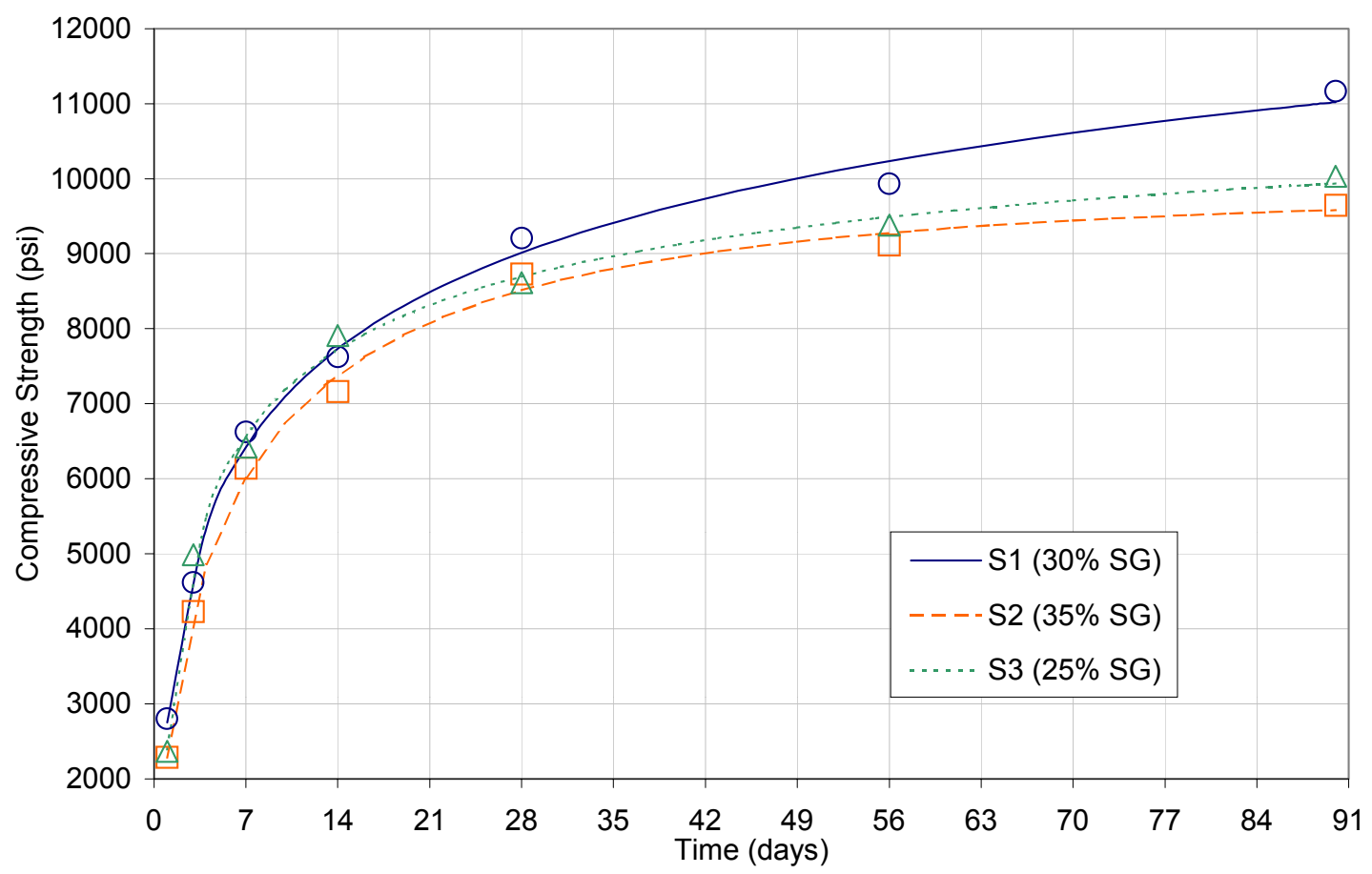

Figure 4.2 Compressive Strength - Age Relationship of Group S HPC 


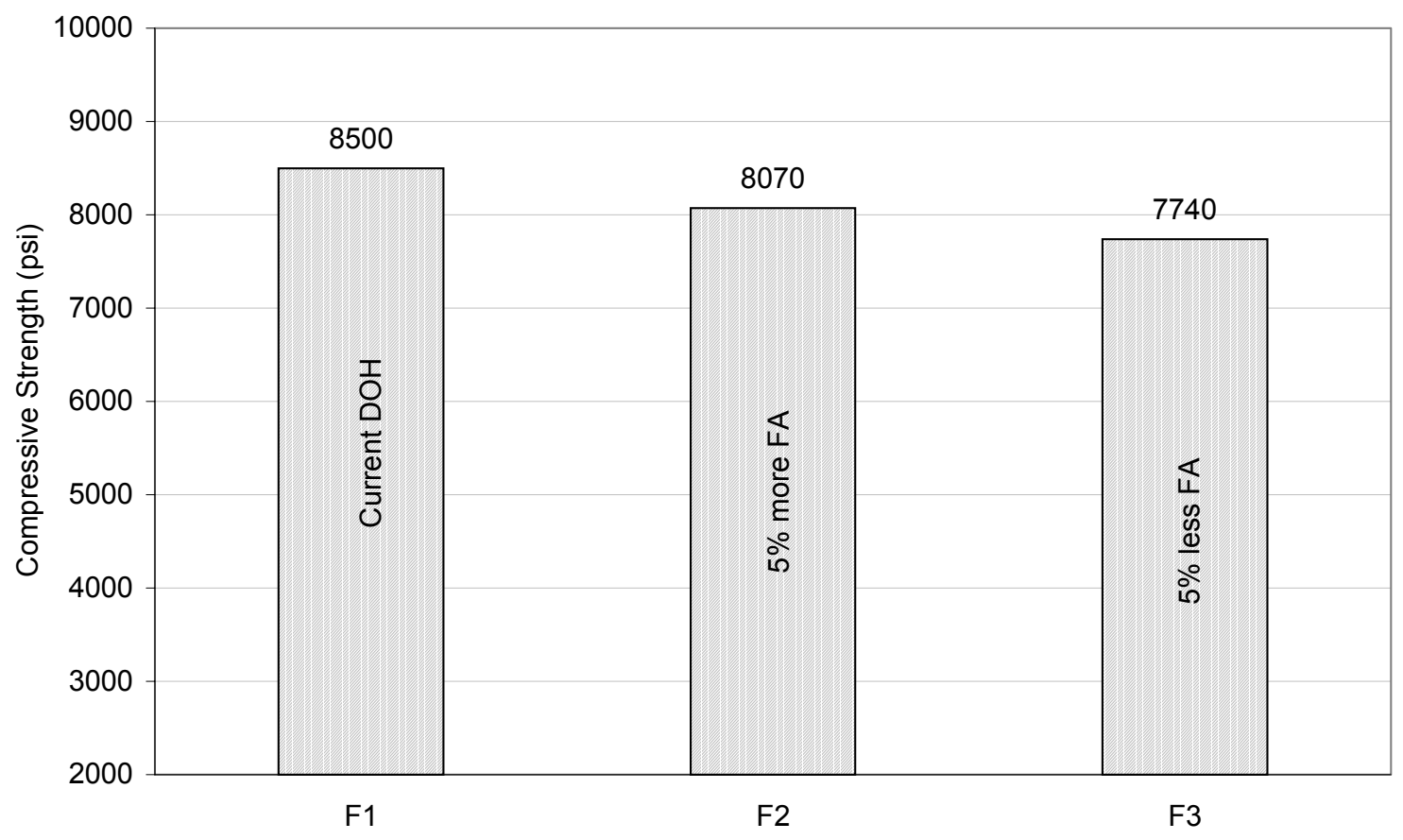

Figure 4.3 28-day Compressive Strength of Group F HPC Mixtures

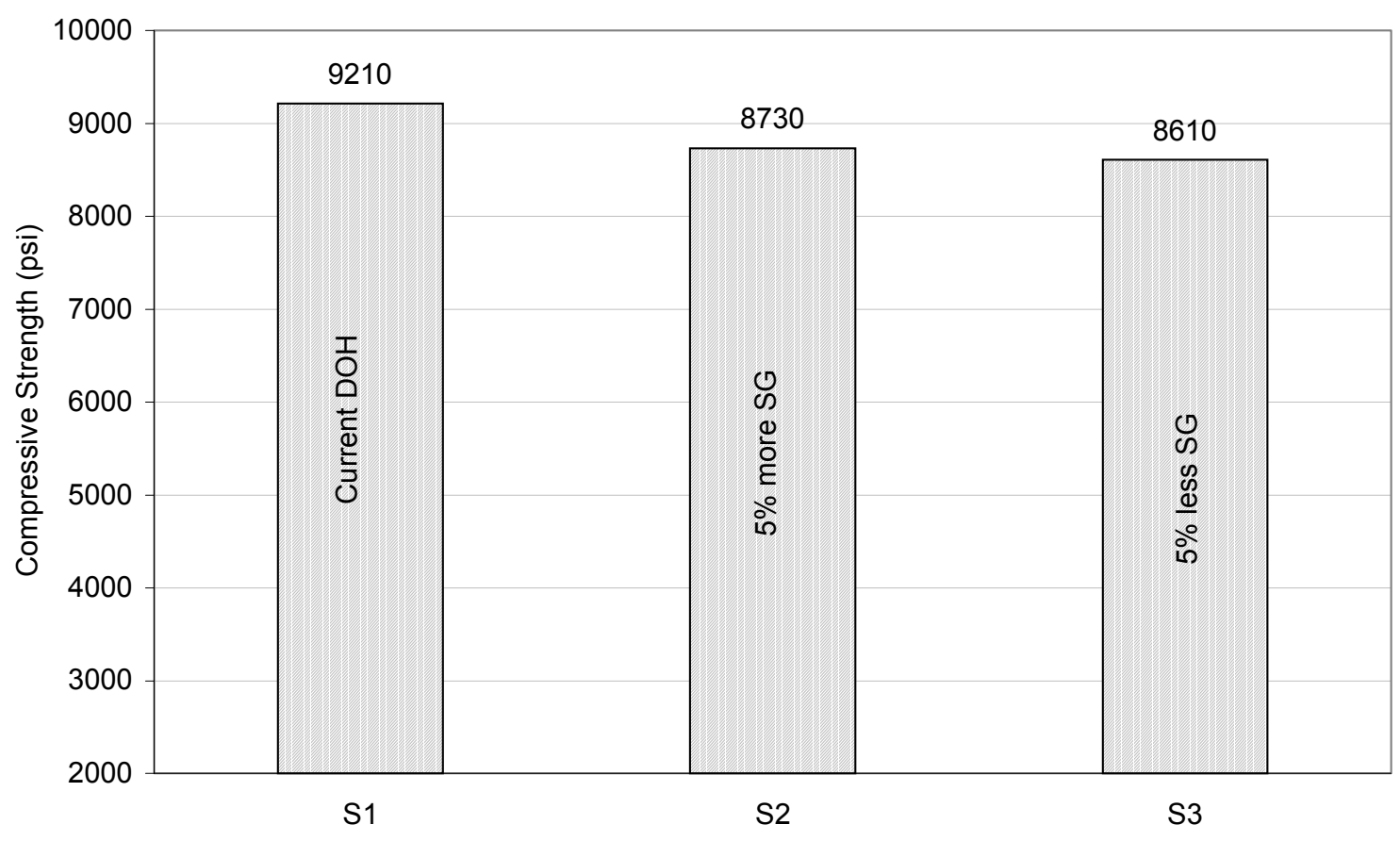

Figure 4.4 28-day Compressive Strength of Group S HPC Mixtures 


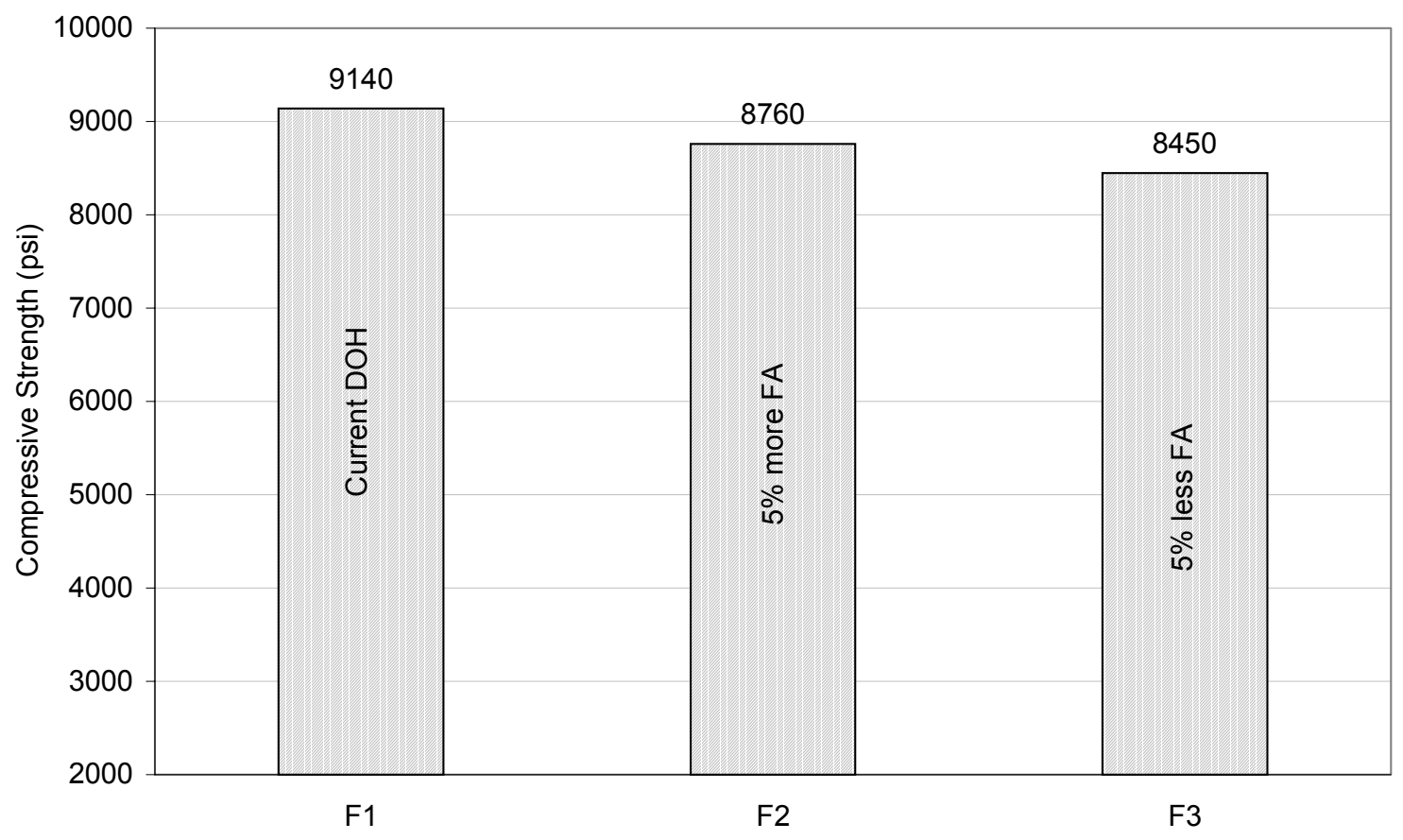

Figure 4.5 56-day Strengths of Group F Mixtures

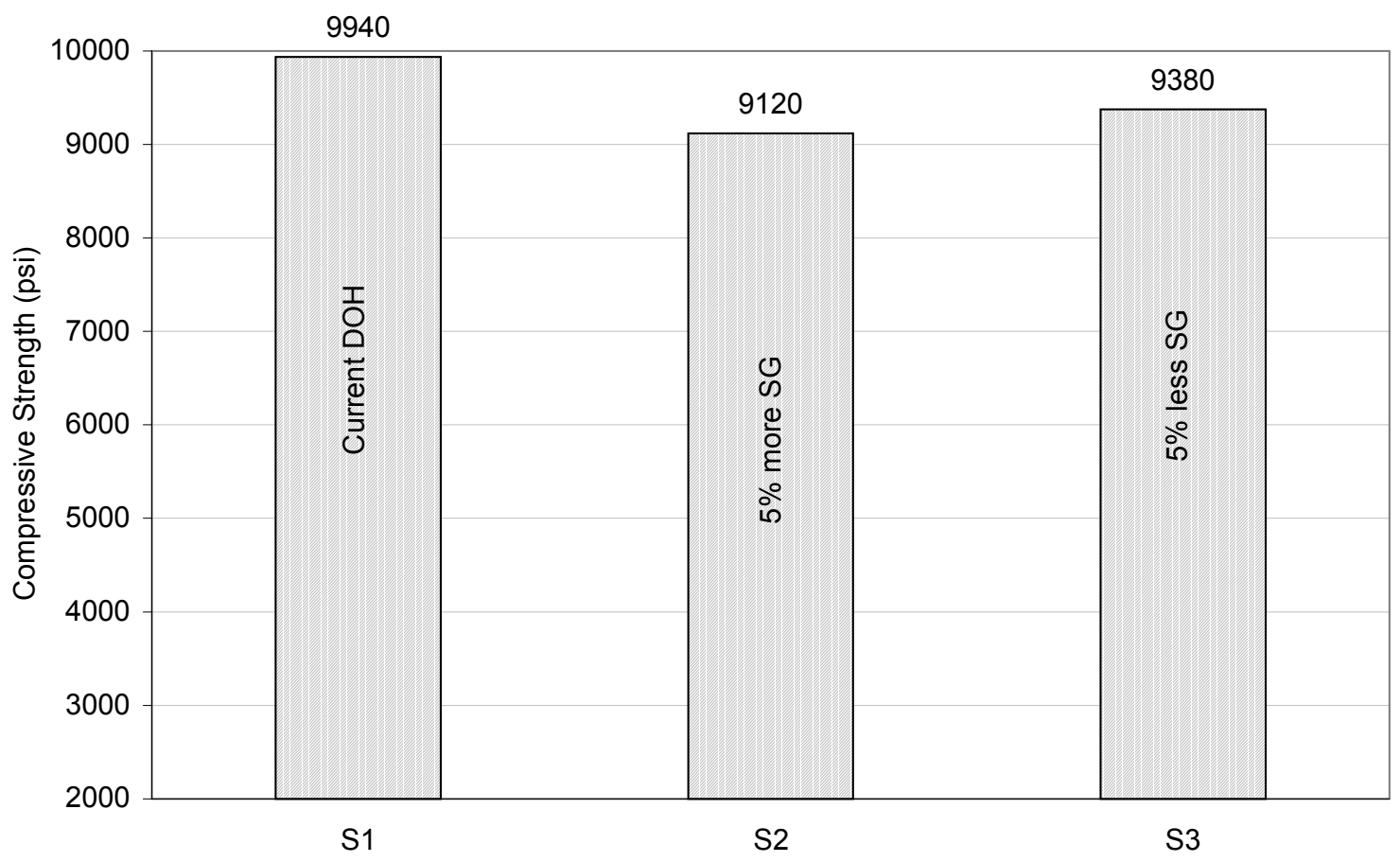

Figure 4.6 56-day Strengths of Group S Mixtures 
Table 4.5 and 4.6, as well as figures 4.1 through 4.6 indicate that the compressive strengths of all HPC mixtures increased steadily with time.

Tables 4.5 and 4.6 show that up to 3 days, the HPC with fly ash achieved compressive strengths at higher rates than the HPC with slag. The W/Cm ratio and cement factor being the same, the design of the mixture proportioning allowed fly ash concrete to develop strength at a faster rate than that of slag concrete at very early age (up to 3 days). However beyond 3 days, the slag concrete gained strength at a much faster rate than the fly ash concrete. Ozyildirim and Hastead (1988) reported a similar behavior of slag-concrete. The maximum compressive strength achieved by the HPC of Group F at 90 days was 9630 psi (F1 mixture), while the corresponding value for the HPC of Group S was 11170 psi (S1). At 28 days (the age of traditional design strength) the HPC of Group F achieved 8500 psi (F1), while the HPC of Group S reached 9210 psi (S1).

Figure 4.1 indicates that among the fly ash group, initially the rate of gain of compressive strength for F1 (current WVDOH) was slightly higher than the other two mixtures, but at later age (90-day), the HPC with higher fly ash content (F2) reached almost the same value as that of F1 (current WVDOH). The pozzolanic reaction of relatively higher quantity of fly ash helped the F2 mixture gain higher compressive strength at later ages.

Comparisons of both 28-day and 56-day compressive strengths among the F Group mixtures (Figure 4.3 and Figure 4.4) show that the current WVDOH HPC (F1) has the highest compressive strength followed by F2 and F3. Both 28-day and 56-day compressive strengths are important, since 28-day strength is used traditionally as design 
strength and 56-day strength was recently recommended by the Federal Highway Administration (FHWA) (Good Speed et al., 1996) as the strength parameter in assessing HPC.

Test results show that higher fly ash content $(25 \%$ by weight of total cementitious material) reduces slightly the 28-day and 56-day compressive strength over the current WVDOH mixture, but the strength values are reasonably good (8070 and 8760 psi respectively) to be used as HPC for bridge decks. The mixture with lower fly ash content ( $15 \%$ by weight of total cementitious material) exhibited the lowest 28 -day and 56-day compressive strengths.

Similar results were obtained in Texas, where two bridges were constructed with HPC (Ralls, 1999) using Fly ash as partial replacement of cement at $28 \%$ to $32 \%$ by weight. The 28-day strength of the bridge deck concrete was in the range of 6000 to 8000 psi. Also in Nebraska (Beacham, 1999), Class C Fly ash was used in one HPC bridge deck, with $10 \%$ fly ash by weight, they reported a 56-day compressive strength of 9100 psi.

Among the HPC corresponding to the slag group, rate of gain of compressive strength (Figure 4.2) of S1 (current WVDOH) was the highest, and the rate of compressive strength gain of S2 and S3 were lower than S1 but close to each other. Figure 4.4 and 4.6 show that the S1 mixture has the highest 28-day and 56-day compressive strengths, while the corresponding 28-day values for S2 and S3 mixtures were close to the S1 mixture. Although concrete with higher slag content $(35 \%$ by weight of cementitious material) attained lower compressive strength compared to the current WVDOH, the values are reasonably good (28-day strength $=8730$ psi, and 56- 
day strength $=9120 \mathrm{psi}$ ) to be used as HPC for bridge decks. The mixture with lower slag content, which is the one with higher cement content, exhibited the lowest 28-day compressive strength.

Ozyildirim (1999) showed in a recent study that the 28-day strengths of two bridge deck concretes made with $50 \%$ of slag (by weight) were 8710 psi and 6681 psi, respectively.

\subsection{Length Change Measurement (Shrinkage)}

The length change test, or free shrinkage, of concrete specimens was performed according to the standard test method ASTM C157, Length Change of Hardened Hydraulic-Cement Mortar and Concrete, and AASHTO T 160. After 7 days of moist curing in lime water at $73 \pm 3{ }^{\circ} \mathrm{F}$, the length change was noted at $4,7,14,21,28,35,42$, 49 , and 56 days to measure the drying shrinkage in air at $50 \% \pm 4 \% \mathrm{Rh}$ and $73 \pm 3{ }^{\circ} \mathrm{F}$. 7 days of moist curing was chosen to simulate the field condition of class $\mathrm{H}$ concrete in bridge decks, where the minimum curing time is recommended as 7 days.

The data for each specimen and mixture type are listed in Appendix B (Tables B.1 through B.6). We summarize the test results of all the mixtures in Tables 4.8 and Table 4.9 . 
Table 4.8 Drying Shrinkage of Group F HPC at Different Ages

\begin{tabular}{|c|c|c|c|}
\hline \multirow{2}{*}{$\begin{array}{c}\text { Days of drying } \\
\text { (After Curing) }\end{array}$} & F1 (current DOH) & F2 (5\% more FA) & F3 (5\% less FA) \\
\cline { 2 - 4 } & (micro strain) & (micro strain) & (micro strain) \\
\hline 4 & 152 & 165 & 195 \\
\hline 7 & 232 & 251 & 288 \\
\hline 14 & 285 & 339 & 344 \\
\hline 21 & 336 & 308 & 365 \\
\hline 28 & 331 & 349 & 347 \\
\hline 35 & 304 & 360 & 373 \\
\hline 42 & 307 & 384 & 411 \\
\hline 49 & 301 & 341 & 395 \\
\hline 56 & 315 & 341 & 368 \\
\hline
\end{tabular}

Table 4.9 Drying Shrinkage of Group S HPC at Different Ages

\begin{tabular}{|c|c|c|c|}
\hline \multirow{2}{*}{$\begin{array}{c}\text { Days of Drying } \\
\text { (After curing) }\end{array}$} & S1 (current DOH) & S2 (5\% more SG) & S3 (5\% less SG) \\
\cline { 2 - 4 } & (micro strain) & (micro strain) & (micro strain) \\
\hline 4 & 212 & 172 & 144 \\
\hline 7 & 272 & 248 & 197 \\
\hline 14 & 296 & 296 & 325 \\
\hline 21 & 356 & 301 & 339 \\
\hline 28 & 368 & 315 & 323 \\
\hline 35 & 392 & 376 & 360 \\
\hline 42 & 356 & 339 & 339 \\
\hline 49 & 360 & 315 & 315 \\
\hline 56 & 336 & 296 & 320 \\
\hline
\end{tabular}

Figure 4.7 and Figure 4.8 show the best-fit shrinkage-time plots for Group F HPC and Group S HPC, respectively. The general form of best-fit equation is

$$
S(t)=S_{s}\left(1-e^{\left(-t / t_{0}\right)}\right)
$$

Where, 
$\mathrm{t}$ - drying time in days, $1 \leq \mathrm{t} \leq 56$

$\mathrm{S}(\mathrm{t})$ - shrinkage at time $\mathrm{t}$

and the parameters defining EQ.4.2 are furnished in Table 4.10.

Figures 4.9 and 4.10 present the average shrinkage values of Group F and Group S HPC, respectively, for data collated at 14 days of drying. Figures 4.11 and 4.12 present the shrinkage values of Group F and Group S HPC, respectively, at 28 days of drying.

Table 4.10 Parameters for Weibull Data Fit

\begin{tabular}{|c|c|c|c|c|c|c|}
\hline Parameters & $F 1$ & $F 2$ & $F 3$ & $S 1$ & S2 & S3 \\
\hline$S_{S}$ & 302.1 & 346.2 & 372.8 & 357.0 & 326.0 & 334.1 \\
\hline$t_{0}$ & 5.03 & 5.63 & 5.14 & 4.96 & 5.27 & 6.58 \\
\hline$R$ & 0.972 & 0.985 & 0.987 & 0.985 & 0.980 & 0.986 \\
\hline
\end{tabular}

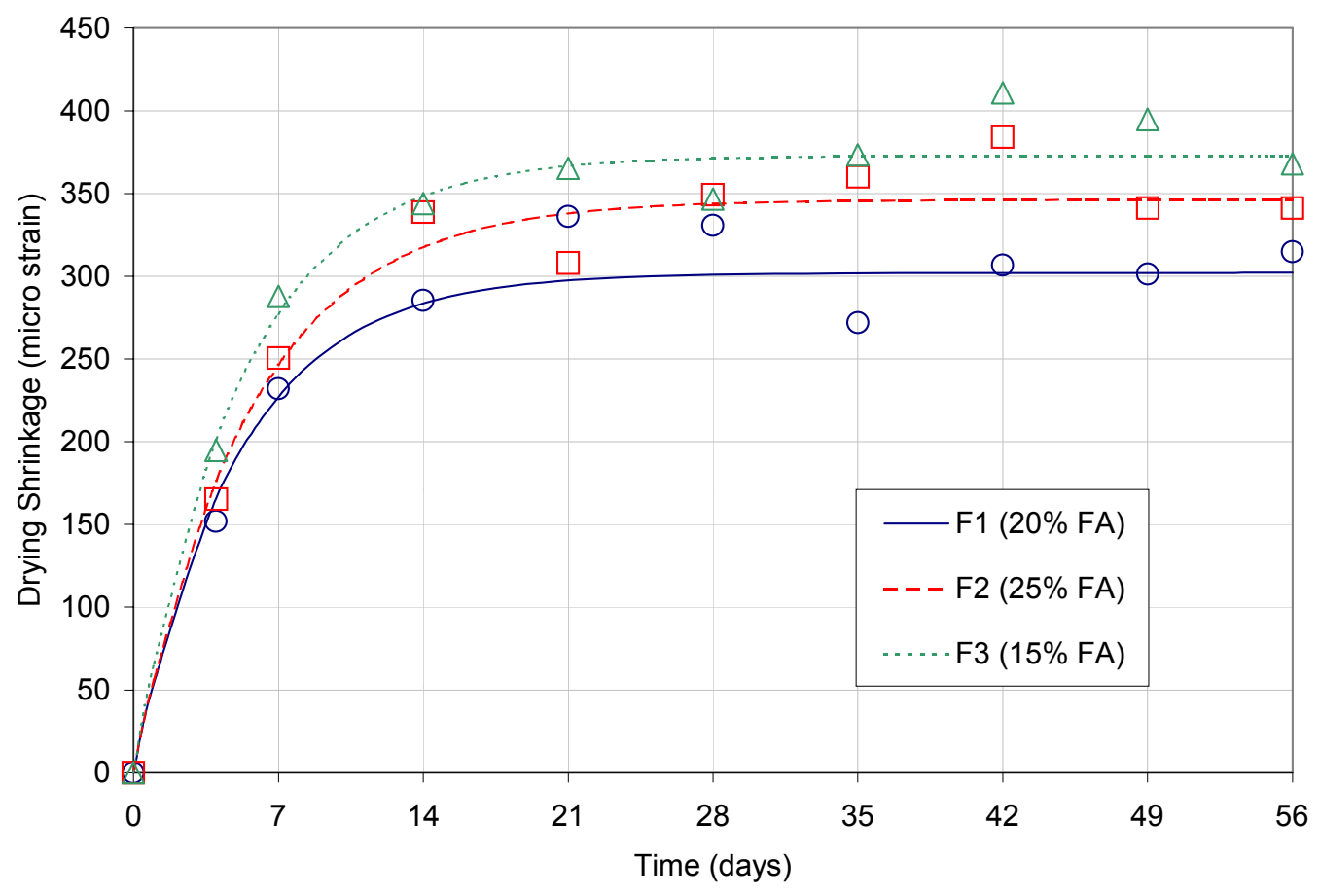

Figure 4.7 Drying Shrinkage of Group F HPC at Different Ages (After 7 days of moist curing at $73 \pm 3^{\circ} \mathrm{F}$ ) 


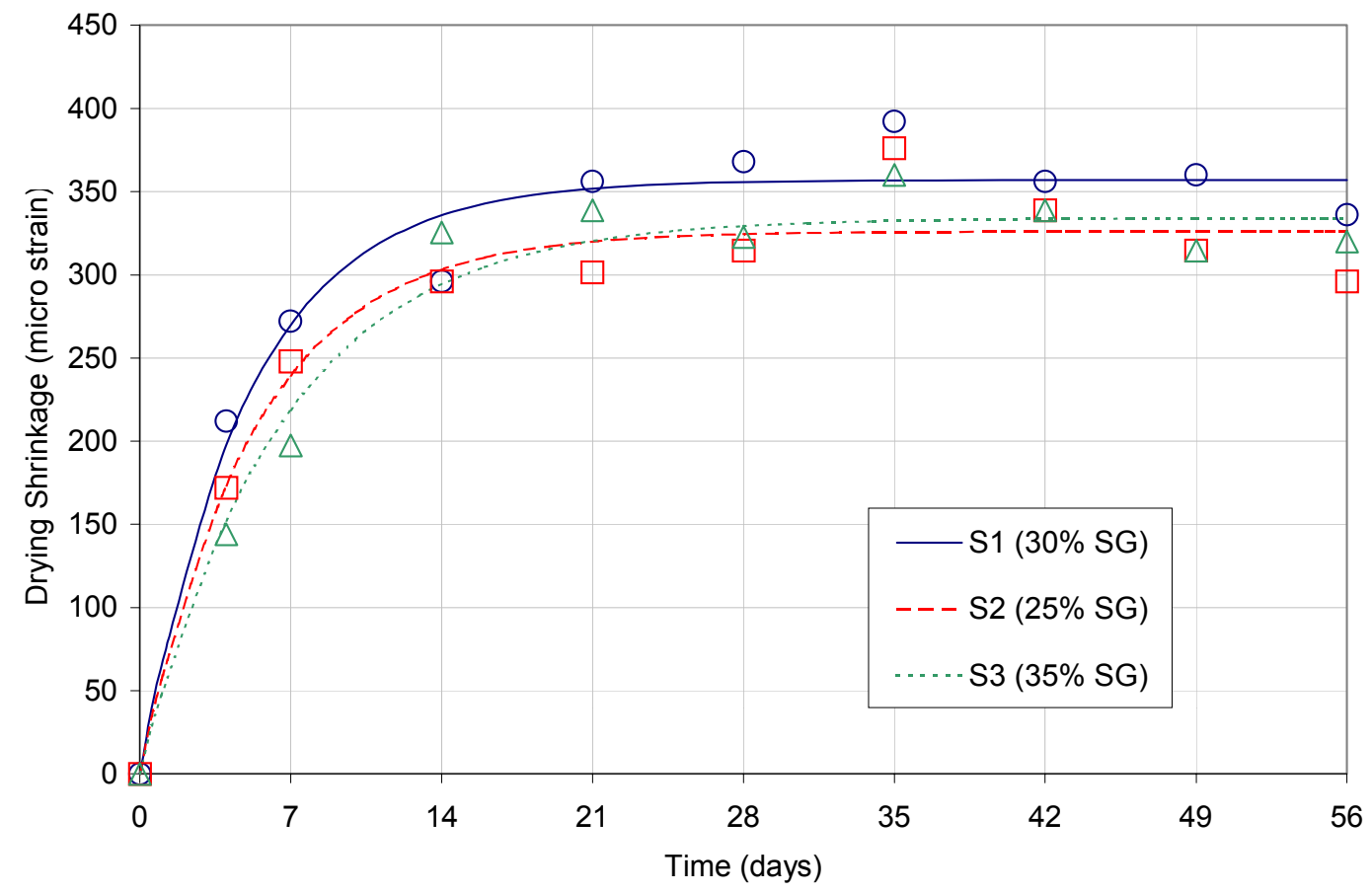

Figure 4.8 Drying Shrinkage of Group S HPC at Different Ages

(After 7 days of moist curing at $73 \pm 3{ }^{\circ} \mathrm{F}$ )

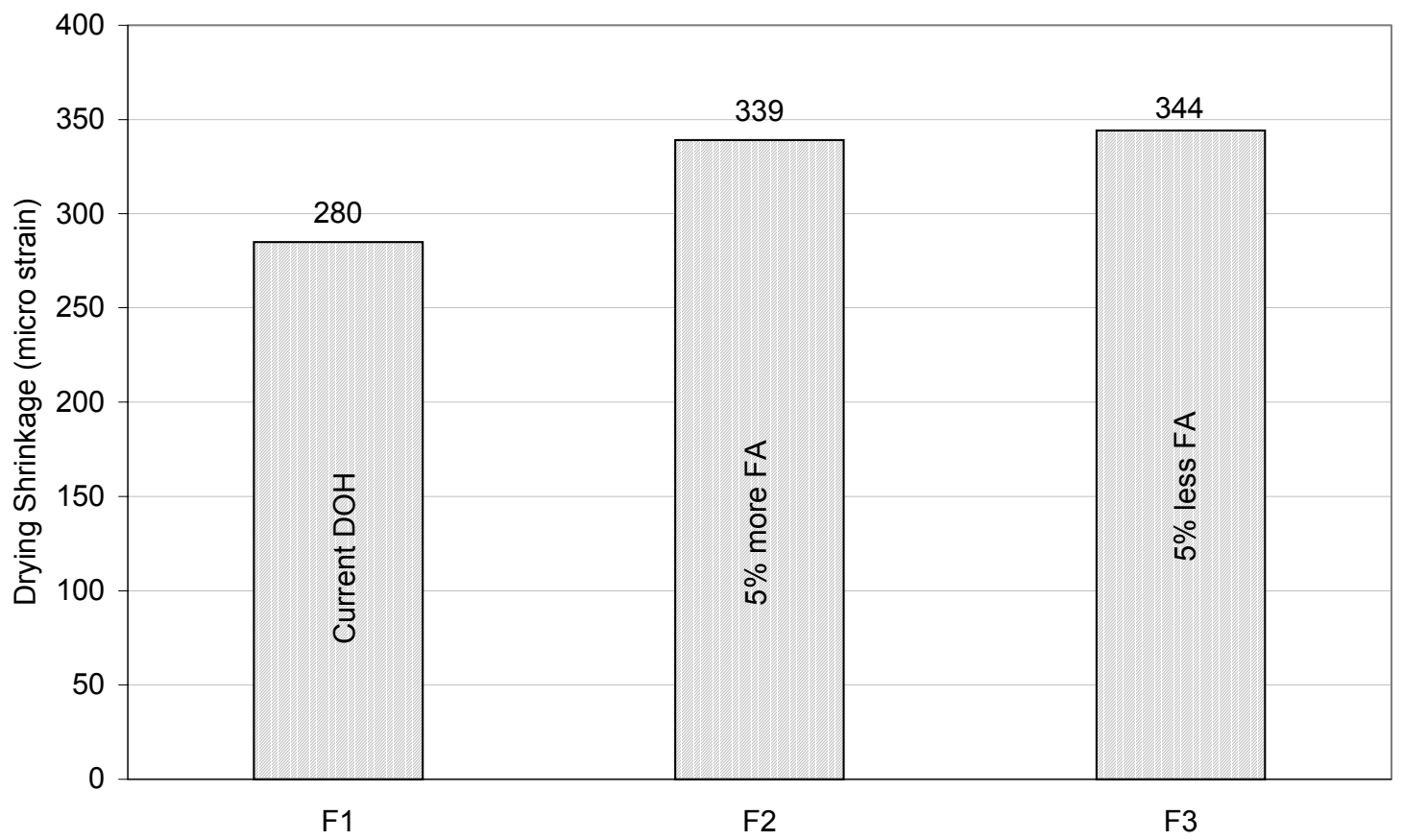

Figure 4.9 Drying Shrinkage of Group F HPC at 14 Days of Drying 


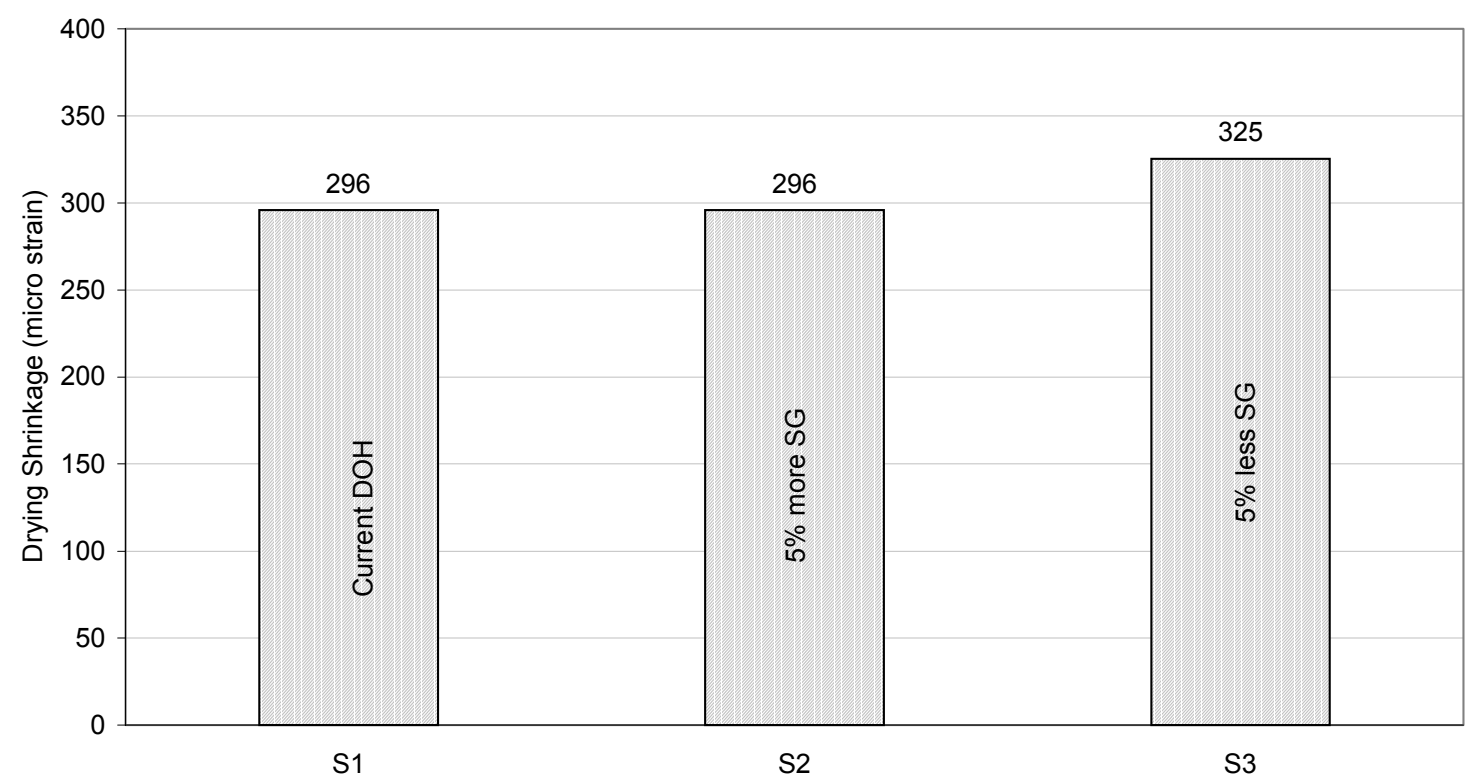

Figure 4.10 Drying Shrinkage of Group S HPC at 14 Days of Drying

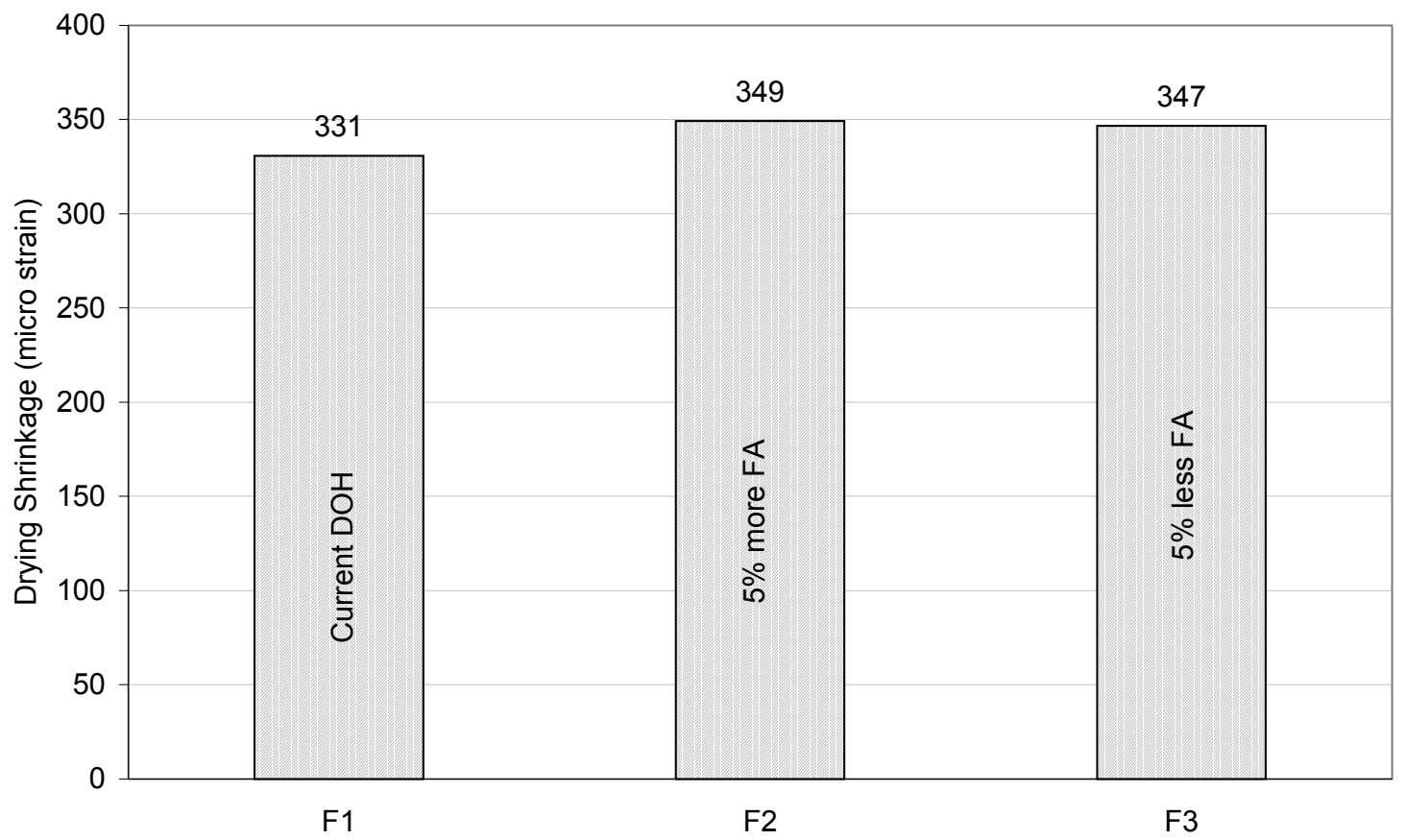

Figure 4.11 Drying Shrinkage of Group F HPC at 28 Days of Drying 


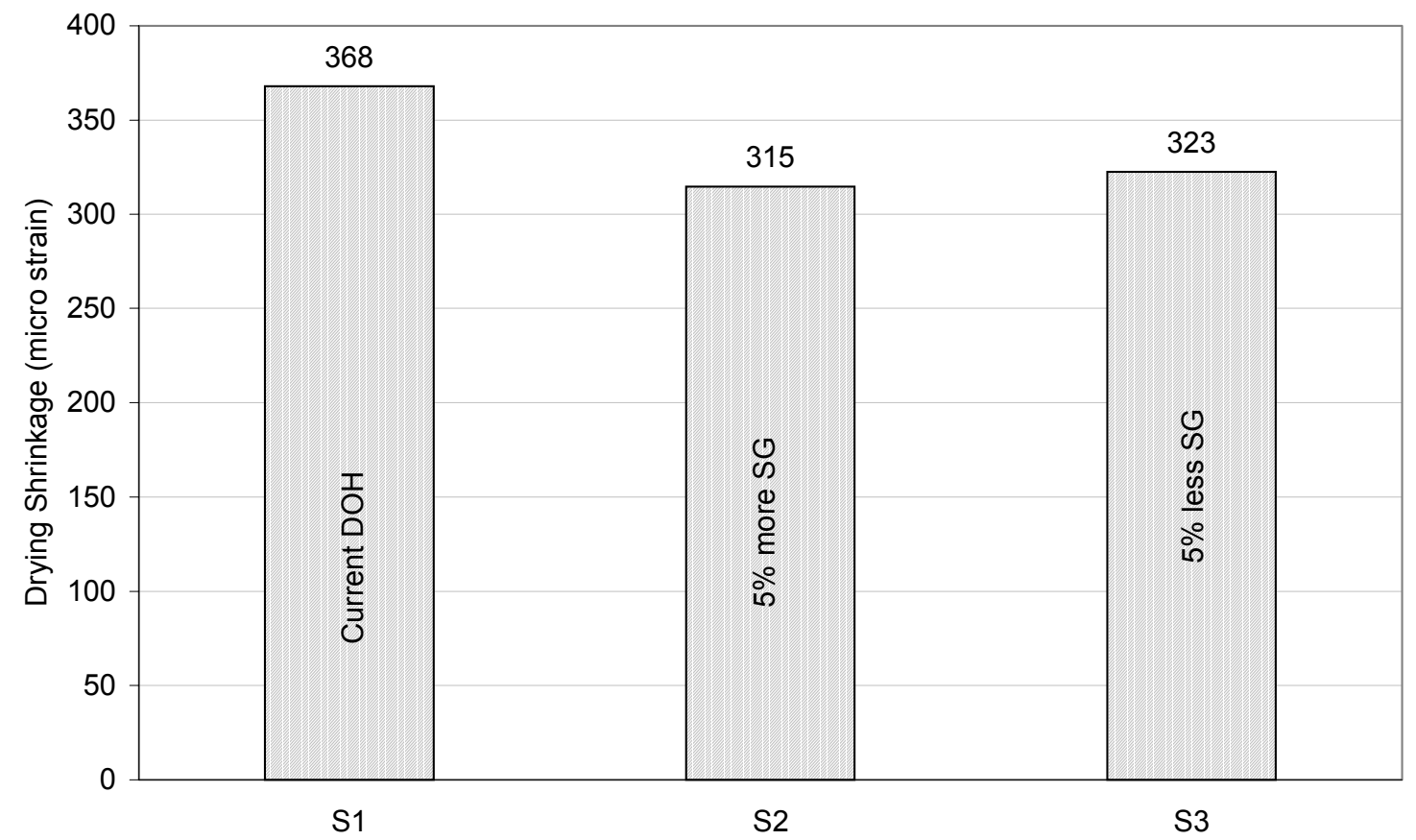

Figure 4.12 Drying Shrinkage of Group S HPC at 28 Days of Drying

Table 4.8 shows the average drying shrinkage values of F1, F2 and F3 mixtures for up to 56 days, which are plotted in Figure 4.7 by a best-fit curve. The Figure shows that drying shrinkage increased rapidly up to 7 days, and then the rate of increase reduced. After about 14 days, the rate of increase became quite low, with almost a flat slope. Among the three mixtures, F1 (the Current WVDOH mixture) reached a steady state earlier than F2 and F3. Finally at 56 days the mean value for F1 was the lowest, followed closely by F2 and F3. In fact, the 56 days drying shrinkage values of all the specimens for all three mixtures were within a close range of 300 micro strains to 375 micro strains. The present test was conducted on specimens that were moist cured for the first 7 days, and the initial drying shrinkage soon after casting was not recorded. The present test was conducted following ASTM C 157 as stated in the WVDOH 
specification for Class $\mathrm{H}$ concrete. Therefore, the data here may be assumed to be useful for all practical purposes as long as a continuous seven days moist curing of HPC deck is performed in the field.

Table 4.9 shows the average drying shrinkage values of S1, S2 and S3 mixtures for up to 56 days, which are plotted in Figure 4.8 by a best-fit curve. The Figure shows that shrinkage increased rapidly up to 7 days, and then the rate of increase reduced. After about 14 days, the rate of increase became very low, and the trend is very much similar to that of the fly ash concrete. Among the three mixtures of the Group S HPC, the S2 and S3 showed a slightly lower range of drying shrinkage (about 320micro strains at 28 days) compared to S1 (current WVDOH) that was about 370 micro strains at 28 days. In general the 56-day shrinkage values for all the Group $\mathrm{S}$ mixtures were within a reasonable range of about 300 micro strains to 350 micro strains and also were very close to the Group F values. As with the Group F, very early shrinkage data was not collected for the Group S specimens.

In summary, the shrinkage values in general changed very little beyond 14 days of drying. Figures 4.9 and 4.11 show that for the Group F mixtures, the current WVDOH mixture performed slightly better than the F2 and F3 variations. However, the mixture with maximum cement paste/aggregate volume ratio (F3) had the maximum drying shrinkage, which is quite common. For the Group S mixtures, both the current WVDOH mixture (S1) and S2 showed similar shrinkage values, while the mixture with the highest value of cement paste/aggregate volume ratio (S3) exhibited the maximum drying shrinkage. 


\subsection{Rapid Freeze/Thaw Test}

The freeze/thaw test was performed according to the standard method ASTM C666, Resistance of Concrete to rapid freezing and thawing, and AASHTO T 161.

The detail test data for each specimen of each mixture type can be found in Appendix C (Tables C.1 through C.7). Table 4.11 and Table 4.12 summarize the dynamic modulus of elasticity values for both Group F and Group S HPC. Table 4.13 provides the percent durability factor, based on the dynamic modulus at 300 cycles with respect to the initial value. Since mixture S1 did not reach the required 300 cycles, the measurement of durability factor is not reported.

The dynamic Young's modulus, $\mathrm{E}_{\mathrm{d}}$, was calculated using the following equation [ASTM C 215]

$$
E_{d}=C W n^{2}
$$

where:

$\mathrm{W}$ - Specimen weight in $\mathrm{lb}$

$\mathrm{n}-$ Fundamental traverse frequency in $\mathrm{Hz}$

$\mathrm{C}-0.00245\left(\mathrm{~L}^{3} \mathrm{~T} / \mathrm{bt}^{3}\right)$ for the prism specimen

$\mathrm{L}$ - Specimen length in inch

$\mathrm{b}, \mathrm{t}-$ specimen cross section dimensions in inch

$\mathrm{T}-\mathrm{A}$ correction factor followed by interpolation as 1.23

The relative dynamic modulus of elasticity after 300 cycles was calculated using the following equation [ASTM, C 666]

$$
P_{c}=\left(n_{1}^{2} / n^{2}\right) \times 100
$$

Where: 
$\mathrm{P}_{\mathrm{c}}=$ percent relative dynamic modulus of elasticity, after $\mathrm{c}$ cycles of freezing and thawing,

$\mathrm{n}=$ initial fundamental transverse frequency before freezing and thawing, and

$\mathrm{n}_{1}=$ fundamental transverse frequency after $\mathrm{c}$ cycles of freezing and thawing.

The durability factor was calculated using the following equation [ASTM, C 666]

$$
D F=P_{c} N / M
$$

Where:

$\mathrm{DF}=$ durability factor of the test specimen,

$\mathrm{Pc}=$ relative dynamic modulus of elasticity at $\mathrm{N}$ cycles in percentage,

$\mathrm{N}=$ number of cycles at which $\mathrm{Pc}$ reaches the specified minimum value for discontinuing the test or the specified number of cycles at which the exposure is to be terminated, whichever is less, and

$M=$ Specified number of cycles at which the exposure is to be terminated.

Since in this study, $\mathrm{N}=\mathrm{M}, \mathrm{DF}=\mathrm{P}_{\mathrm{c}}=\left(\mathrm{n}_{1}^{2} / \mathrm{n}^{2}\right) \times 100$.

Table 4.11 Dynamic Modulus of Mixtures in Group F

\begin{tabular}{|c|c|c|c|}
\hline Freezing/Thawing & $\mathrm{F} 1$ & $\mathrm{~F} 2$ & $\mathrm{~F} 3$ \\
\hline (Cycles) & $\left(\times 10^{4} \mathrm{psi}\right)$ & $\left(\times 10^{4} \mathrm{psi}\right)$ & $\left(\times 10^{4} \mathrm{psi}\right)$ \\
\hline Initial & 608 & 638 & 620 \\
\hline 50 & 600 & 640 & 630 \\
\hline 100 & 608 & 647 & 608 \\
\hline 150 & 590 & 632 & 611 \\
\hline 200 & 600 & 632 & 611 \\
\hline 250 & 608 & 644 & 621 \\
\hline 300 & 605 & 629 & 607 \\
\hline
\end{tabular}


Table 4.12 Dynamic Modulus of Mixtures in Group S

\begin{tabular}{|c|c|c|c|}
\hline Freezing/Thawing & $\mathrm{S} 1$ & $\mathrm{~S} 2$ & $\mathrm{~S} 3$ \\
\hline (Cycles) & $\left(\times 10^{4} \mathrm{psi}\right)$ & $\left(\times 10^{4} \mathrm{psi}\right)$ & $\left(\times 10^{4} \mathrm{psi}\right)$ \\
\hline Initial & 647 & 604 & 613 \\
\hline 50 & 629 & 592 & 601 \\
\hline 100 & 600 & 577 & 604 \\
\hline 150 & 614 & 598 & 578 \\
\hline 200 & 623 & 592 & 612 \\
\hline 250 & 621 & 606 & 598 \\
\hline 300 & $\mathrm{~N} / \mathrm{A}$ & 602 & 601 \\
\hline
\end{tabular}

Note: $\mathrm{N} / \mathrm{A}=$ Not available at this time

Table 4.13 Durability Factor of Group F and Group S HPC

\begin{tabular}{|c|c|c|c|c|c|c|}
\hline Mixture & F1 & F2 & F3 & S1 & S2 & S3 \\
\hline DF (\%) & 99 & 97 & 96 & N/A & 99 & 96 \\
\hline
\end{tabular}

Note: $\mathrm{N} / \mathrm{A}=$ Not available at this time

Table 4.11 shows that among the Group F mixtures, F2 had the highest initial dynamic modulus of elasticity $\left(E_{d}\right)$ followed by F3 and F1. The results indicate that $E_{d}$ values as measured by resonant frequency changed little even after 300 cycles. Since all the concrete mixtures have air contents of $5 \%$ to $7 \%$ and are much less permeable, thus less porous, than conventional concrete, the deterioration due to freeze-thaw cycles was not significant. The durability factor (Table 4.13) indicates that the F1 (current WVDOH) HPC was practically unchanged after 300 cycles, although the F2 and F3 mixtures also deteriorated very little.

Table 4.12 shows that among the Group S mixtures, S1 (current WVDOH) had the highest initial dynamic modulus of elasticity followed by S3 and S2. The data for 
300 cycles of Freeze-thaw was not available for S1, but a comparison of mixtures for up to 250 cycles showed that $\mathrm{S} 1$ had undergone maximum loss in $\mathrm{E}_{\mathrm{d}}$ (by $4.1 \%$ ), while the change in $\mathrm{E}_{\mathrm{d}}$ for $\mathrm{S} 2$ was negligible (1.8\%), and S3 did not show any significant changes for up to 250 cycles. In general, the deterioration under Freeze-thaw was not significant because the mixtures had an air content of $5.2 \%$ to $7.0 \%$.

It is presumed that samples under freeze-thaw cycles beyond 400 may show some sign of deterioration. It was observed that the bottom of most of the specimens had some of degree of scaling. The loss of weight of the specimens, however, was not significant.

As a point of comparison, a HPC mixture developed in New Hampshire (Waszczuk and Juliano, 1999) for bridge decks using Type II cement, silica fume, AEA, HRAWA, corrosion inhibitor, and local aggregates showed a freeze-thaw durability factor of $96 \%$ to $99 \%$.

\subsection{Rapid Chloride Permeability Test}

The Rapid chloride permeability test (RCPT) was performed on 35-42 days cured disc specimens according to the standard test method ASTM C1202, Electrical Indication of Concrete's Ability to Resist Chloride Ion Penetration, and AASHTO C 277.

Table 4.14 and Table 4.15 summarize the permeability test results of Group F and Group S HPC, respectively. More detail data can be found in Appendix D (Tables D.1 through D.4). Figure 4.13 shows the charge-passed over 6 hours time for Group F mixtures, including the data variation for each type of specimen. Figure 4.14 shows the charge-passed over 6 hours time for Group S mixtures, including the data variation for 
each type of specimens. Figure 4.15 shows a comparison of chloride permeability values among all the mixtures (Group F and Group S).

Table 4.14 Charge-passed (Coulombs) in RCPT for Group F HPC

\begin{tabular}{|c|c|c|c|}
\hline \multirow{2}{*}{$\begin{array}{c}\text { Time } \\
\text { (Minutes) }\end{array}$} & F1 & F2 & F3 \\
\cline { 2 - 4 } & (Coulombs) & (Coulombs) & (Coulombs) \\
\hline 0 & 0 & 0 & 0 \\
\hline 30 & 60 & 66 & 90 \\
\hline 60 & 118 & 136 & 185 \\
\hline 90 & 179 & 207 & 285 \\
\hline 120 & 241 & 282 & 388 \\
\hline 150 & 304 & 358 & 496 \\
\hline 180 & 369 & 437 & 606 \\
\hline 210 & 435 & 517 & 718 \\
\hline 240 & 502 & 599 & 832 \\
\hline 270 & 570 & 683 & 950 \\
\hline 300 & 639 & 769 & 1068 \\
\hline 330 & 708 & 857 & 1188 \\
\hline 360 & 779 & 947 & 1310 \\
\hline
\end{tabular}

Table 4.15 Charge passed (Coulombs) in RCPT for Group S HPC

\begin{tabular}{|c|c|c|c|}
\hline \multirow{2}{*}{$\begin{array}{c}\text { Time } \\
\text { (Minutes) }\end{array}$} & S1 & S2 & S3 \\
\cline { 2 - 4 } & (Coulombs) & (Coulombs) & (Ccoulombs) \\
\hline 0 & 0 & 0 & 0 \\
\hline 30 & 62 & 52 & 70 \\
\hline 60 & 126 & 105 & 144 \\
\hline 90 & 192 & 159 & 220 \\
\hline 120 & 258 & 212 & 299 \\
\hline 150 & 325 & 267 & 379 \\
\hline 180 & 393 & 322 & 460 \\
\hline 210 & 460 & 376 & 543 \\
\hline 240 & 527 & 431 & 627 \\
\hline 270 & 594 & 486 & 712 \\
\hline 300 & 660 & 540 & 798 \\
\hline 330 & 727 & 595 & 885 \\
\hline 360 & 794 & 649 & 972 \\
\hline
\end{tabular}




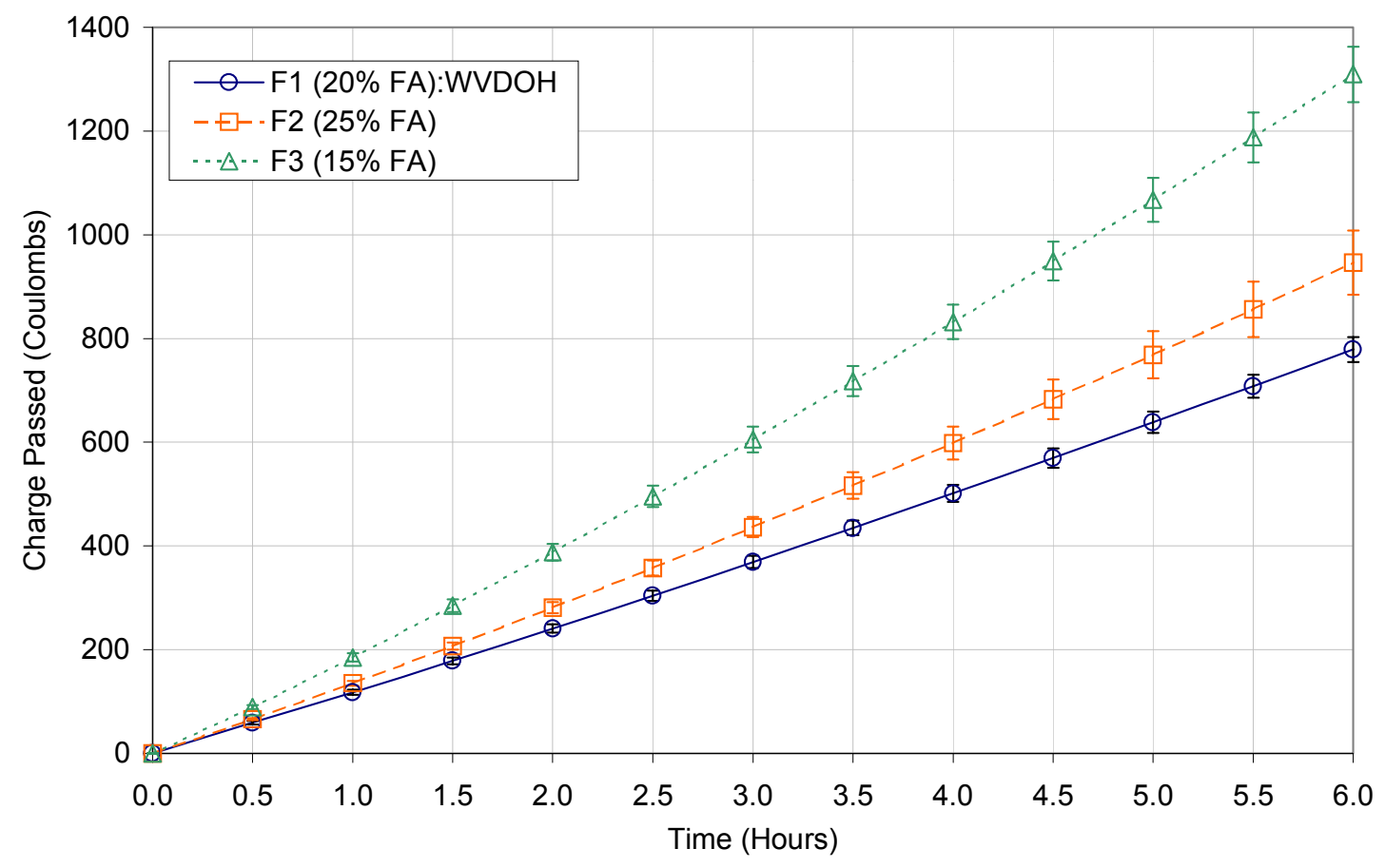

Figure 4.13 Charge-passed in RCPT Test of Mixtures in Group F

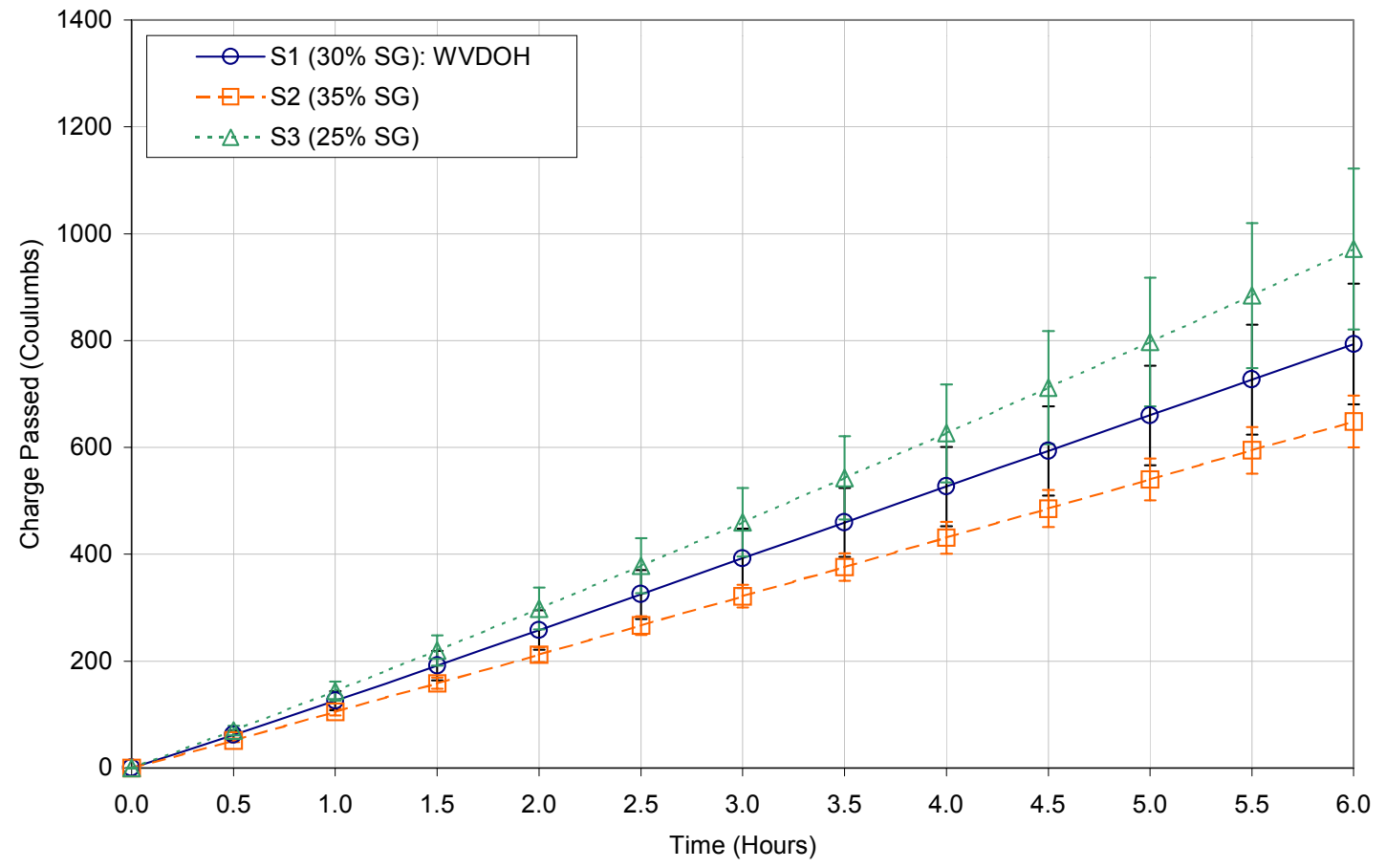

Figure 4.14 Charge-passed in RCPT Test of Mixtures in Group S 


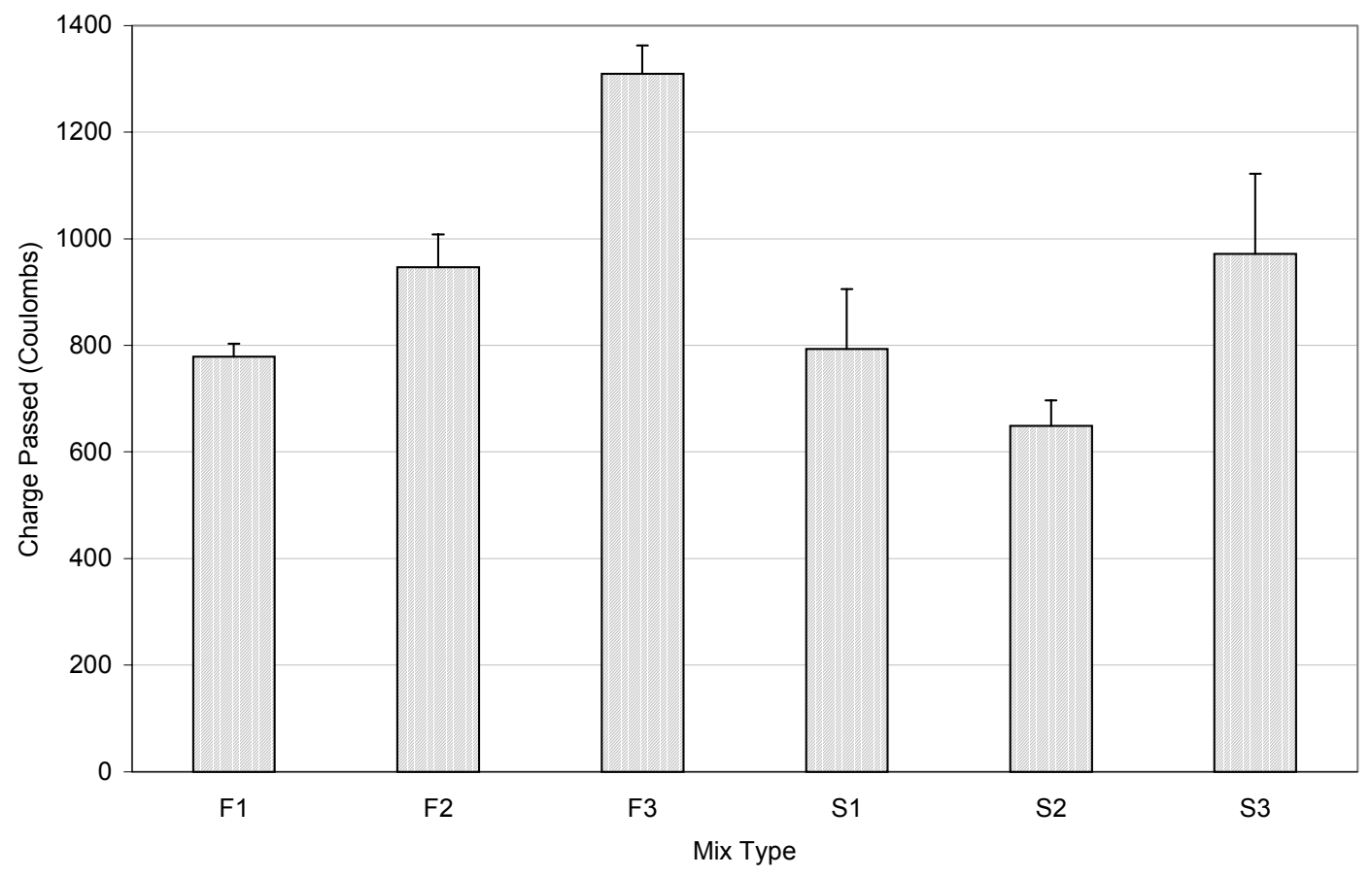

Figure 4.15 Comparison of Chloride Permeability Among Mixtures

Table 4.14 and Figure 4.13 show that among the Group F mixtures, F1 (current WVDOH) had the lowest quantity of charge passed over 6 hours, while F3 (HPC with less fly ash) had the highest value. The charge passed through F2 (HPC with more fly ash) was close (21\% higher) to that recorded for F1.

Table 4.15 and Figure 4.14 indicate that among the Group S mixtures, S2 (HPC with more slag than the current WVDOH) had the lowest amount of charge passed over 6 hours, while S3 (HPC with less slag content) had the highest value. The corresponding values of S1 (current WVDOH) were found to lie in between S2 and S3.

A comparison among all the mixtures indicates that in general the range of chloride permeability (measured as charge passed) was lower for the slag concrete (649 
to 972 Coulombs) than for the fly ash concrete (779 to 1310 Coulombs). The largest difference was between F3 and S3, and there was practically no difference between F1 and S1 (Figure 4.15).

In general all of the six HPC mixtures, except for F3, showed "very low" (ASTM C1202) chloride ion permeability based on charge passed. Ozyidirim (1999) reported about 900 Coulombs of charge using the same test, for 28 -day concrete with $50 \%$ of slag by weight, and $\mathrm{W} / \mathrm{Cm}$ ratio of 0.4 ; the specimens were moist-cured for one week at room temperature $\left(73^{\circ} \mathrm{F}\right)$ and subsequently three weeks at $38^{\circ} \mathrm{C}\left(100^{\circ} \mathrm{F}\right)$.

For a bridge project in Nebraska, Beacham (1999) reported that the HPC mixture they used with $10 \%$ of fly ash by weight at $\mathrm{W} / \mathrm{Cm}$ ratio 0.31 had a chloride permeability of 589 Coulombs at 56 days. However, the curing condition of the specimens was different from the one used in the present study. 


\section{Chapter 5}

\section{Summary and Conclusions}

This chapter summarizes the test results of the six HPC mixture designs developed in this study and draws some conclusions on the basis of the results. A recommendation for future work is also included.

\subsection{Summary of Results}

Based on the experiments and observations of the developed HPC mix proportions, the results are summarized as follows:

1. All of the mixtures except those with lower fly ash and slag contents (compared to the current $\mathrm{WVDOH}$ ) were cohesive and free from bleeding during pouring and vibration of concrete.

2. The concretes with lower fly ash and slag were susceptible to bleeding and segregation under vibration.

3. The range of slump of all HPC mixtures, for both the fly ash and slag groups, was between 5.5 to 7 inches, which satisfies the WVDOH Class $\mathrm{H}$ concrete requirement. The slump was measured approximately 40 to 45 minutes after the addition of water to the cementitious materials. 
4. The air content of all HPC mixtures, for both the fly ash and slag groups, was between $5 \%$ to $7 \%$, which satisfies the WVDOH Class $\mathrm{H}$ concrete requirement. The slag concrete needed more AEA to maintain the air content.

5. The six HPC mixtures attained reasonably good compressive strengths, even at only 3 days of curing. The fly ash HPC attained $8 \%$ to $20 \%$ more 3 -day strength than the slag HPC. However, at later ages (after 14 days), the slag HPC reached higher strength than the fly ash HPC. At 28 days, the slag HPC had $8 \%$ to $12 \%$ higher compressive strength than the corresponding fly ash HPC.

6. Among the fly ash HPC, the current WVDOH mixture had the highest compressive strength, and the HPC with lower fly ash content showed lowest compressive strength.

7. Among the slag HPC, the current WVDOH mixture had the highest compressive strength, and the HPC with lower slag content showed the lowest compressive strength.

8. All six HPC mixtures exhibited gains in strength for up to 90 days (the timespan for which it was measured) under continuous moist curing.

9. The drying shrinkage was more significant during the early periods of drying. About $72 \%$ to $75 \%$ of drying shrinkage occurred within the first 7 days of drying.

10. The best fit curve used for the fly ash HPC specimens indicates that the concrete with the lowest quantity of fly ash had the maximum shrinkage, and the current WVDOH mixture used as a base design had the lowest shrinkage. 
11. The best fit curve used for the slag HPC specimens indicates that the current WVDOH mixture had the highest shrinkage, while the shrinkage values for the HPC with lower and higher slag contents were close to each other.

12. The freeze-thaw durability tests of 250 cycles for the fly ash and slag HPC mixtures did not alter significantly the dynamic modulus of elasticity values. The durability factors computed for the F1, F2, F3 and S3 mixtures show that all those HPC are highly durable, since these durability factors were between $96 \%$ and $99 \%$. It is presumed that because of proper mixture proportioning with appropriate air content, the freeze-thaw cycles of up to 300 did not affect the concrete integrity.

13. The rapid chloride permeability test indicated that among the fly ash HPC, the current WVDOH mixture had the lowest chloride permeability value of about 780 Coulombs is the "very low" category according to ASTM C 1202. The permeability of HPC with high fly ash was about $21 \%$ more than of the current WVDOH mixture.

14. Among the slag HPC mixtures, the HPC with more slag showed the lowest chloride permeability value (about $18 \%$ lower than that of the WVDOH mixture). All the slag HPC mixtures had values within the "very low" category of chloride permeability.

\subsection{Conclusions}

Table 5.1 shows the grade of each of the six HPC mixtures for each of its properties, such as compressive strength, drying shrinkage, freeze-thaw, and chloride 
permeability. The grading is made in accordance with the published document "HighPerformance Concrete Defined for Highway Structures" (Goodspeed et al, 1996). The highest grade is 4 , and conversely, the lowest grade is 1 .

Table 5.1 Grades for Different Characteristics of All Mixtures

\begin{tabular}{||c|c|c|c|c|c|}
\hline \multirow{4}{*}{$\begin{array}{c}\text { Fly } \\
\text { ash }\end{array}$} & $\begin{array}{c}\text { H6-day } \\
\text { Compressive } \\
\text { Strength }\end{array}$ & $\begin{array}{c}\text { Drying } \\
\text { Shrinkage }\end{array}$ & Durability & $\begin{array}{c}\text { Chloride } \\
\text { Permeability }\end{array}$ \\
\cline { 2 - 6 } & WVDOH & Grade 2 & Grade3 & Grade2 & Grade3 \\
\cline { 2 - 6 } & More FA & Grade 2 & Grade3 & Grade2 & Grade2 \\
\cline { 2 - 6 } & Less FA & Grade 2 & Grade3 & Grade2 & Grade2 \\
\hline \multirow{4}{*}{ Slag } & $\begin{array}{c}\text { Current } \\
\text { WVDOH }\end{array}$ & Grade 3 & Grade3 & N/A & Grade3 \\
\cline { 2 - 6 } & More SG & Grade 2 & Grade3 & Grade2 & Grade3 \\
\cline { 2 - 6 } & Less SG & Grade 3 & Grade3 & Grade2 & Grade2 \\
\hline
\end{tabular}

Note: $\mathrm{N} / \mathrm{A}=$ not presently available

From the fly ash group, the current WVDOH and the higher fly ash mixtures are recommended for future studies. From the slag group, also the current WVDOH and the higher slag mixtures are recommended for future studies. Between the fly ash and slag groups, the overall performance of slag group was better. Among all the six HPC mixtures, the concrete with higher slag (35\% slag) was the most cost effective.

In general, for the WV source of limestone and natural river sand aggregates used in this study, the current WVDOH Class $\mathrm{H}$ concretes, as proportioned in this study, are good if the cement factors are specified 624 for the fly ash group, and 647 for the slag group, and if the water/cementitious material ratio is maintained as 0.40 for all mixtures. The addition of more fly ash and slag to the corresponding WVDOH mixtures did not 
affect the performance significantly, but by using a higher quantity of slag, the chloride permeability of the concrete improved. Thus, for future development of HPC mixtures for WV using other sources of aggregates, the mixture designs with higher contents of slag and fly ash (pozzolanic materials) may be recommended due to cost benefits and environmental considerations aimed at using pozzolanic materials as well as reducing $\mathrm{CO}_{2}$ emissions during cement production. 


\section{Bibliography}

1. AASHTO T 22 -92, "Compressive Strength of Cylindrical Concrete Specimens," Standard Specifications for Transportation Materials and Methods of Sampling and Testing, $17^{\text {th }}$ Edition, 1995, pp. 11-17.

2. AASHTO T 119-93, "Slump of Hydraulic Cement Concrete," Standard Specifications for Transportation Materials and Methods of Sampling and Testing, $17^{\text {th }}$ Edition, 1995, pp. 194-195.

3. AASHTO T 121-86, "Weight per Cubic Foot, Yield, and Air Content of Concrete," Standard Specifications for Transportation Materials and Methods of Sampling and Testing, $17^{\text {th }}$ Edition, 1995, pp. 196-198.

4. AASHTO T 152-93, "Air Content of Freshly Mixed Concrete by the Pressure Method," Standard Specifications for Transportation Materials and Methods of Sampling and Testing, $17^{\text {th }}$ Edition, 1995, pp. 255-262.

5. AASHTO T 160-93, "Length Change of Hardened Hydraulic Cement Mortar and Concrete," Standard Specifications for Transportation Materials and Methods of Sampling and Testing, $17^{\text {th }}$ Edition, 1995, pp. 196-198.

6. AASHTO T 161-93, "Resistance of Concrete to Rapid Freezing and Thawing," Standard Specifications for Transportation Materials and Methods of Sampling and Testing, $17^{\text {th }}$ Edition, 1995, pp. 294-299.

7. AASHTO T 277-93, "Electrical Indication of Concrete's Ability to resist Chloride Ion Penetration," Standard Specifications for Transportation Materials and Methods of Sampling and Testing, $17^{\text {th }}$ Edition, 1995, pp. 196-198.

8. American Society for Testing and Materials, 1995 Annual Book of ASTM Standards, vol.04.02, Concrete and Aggregates.

9. ASTM C 39-86, "Standard Test Method for Compressive Strength of Cylindrical Concrete Specimens," in 1995 Annual Book of ASTM Standards, V04.02, Concrete and Aggregates, American Society for Testing and Materials, pp. 20-24. 
10. ASTM C 138-92, "Standard Test Method for Unit Weight, Yield, and Air Content (Gravimetric) of Concrete," in 1995 Annual Book of ASTM Standards, V04.02, Concrete and Aggregates, American Society for Testing and Materials, pp. 83-85.

11. ASTM C 143-90a, "Standard Test Method for Slump of Hydraulic cement concrete," in 1995 Annual Book of ASTM Standards, V04.02, Concrete and Aggregates, American Society for Testing and Materials, pp. 88-90.

12. ASTM C 157-93, "Standard Test Method for Length Change of Hardened Hydraulic-Cement Mortar and Concrete," in 1995 Annual Book of ASTM Standards, V04.02, Concrete and Aggregates, American Society for Testing and Materials, pp. 101-106.

13. ASTM C 192-90a, " Standard Practice for Making and Curing Test Specimens in the Laboratory," in 1995 Annual Book of ASTM Standards, V04.02, Concrete and Aggregates, American Society for Testing and Materials.

14. ASTM C 215-91, “ Standard Test Method for Fundamental Transverse, Longitudinal, and Torsional Frequencies of Concrete Specimens," in 1995 Annual Book of ASTM Standards, V04.02, Concrete and Aggregates, American Society for Testing and Materials.

15. ASTM C 231-91b, "Standard Test Method for Air Content of Freshly Mixed Concrete by the Pressure Method," in 1995 Annual Book of ASTM Standards, V04.02, Concrete and Aggregates, American Society for Testing and Materials, pp. $140-147$.

16. ASTM C 618-99a, "Standard Specification for Coal Fly Ash and Raw or Calcined Natural Pozzolan for Use as a Mineral Admixture in Concrete," in 2000 Annual Book of ASTM Standards, V04.02, Concrete and Aggregates, American Society for Testing and Materials, pp. 305-308.

17. ASTM C 666-92, "Standard Test Method for resistance of concrete to Rapid freezing and Thawing," in 1995 Annual Book of ASTM Standards, V04.02, Concrete and Aggregates, American Society for Testing and Materials, pp. 345347.

18. ASTM C 989-99, "Standard Specification for Ground Granulated Blast-Furnace Slag for Use in Concrete," in 2000 Annual Book of ASTM Standards, V04.02, 
Concrete and Aggregates, American Society for Testing and Materials, pp. 513517.

19. ASTM C 1064-86, "Standard Test Method for Temperature of freshly Mixed Portland cement concrete," in 1995 Annual Book of ASTM Standards, V04.02, Concrete and Aggregates, American Society for Testing and Materials, pp. 528529.

20. ASTM C 1202-91, "Standard Test Method for Electrical Indication of Concrete's Ability to Resist Chloride Ion Penetration," in 1995 Annual Book of ASTM Standards, V04.02, Concrete and Aggregates, American Society for Testing and Materials, pp. 627-632.

21. ASTM C 1240-00, "Standard Specification for Use of Silica Fume as a Mineral Admixture in Hydraulic -Cement Concrete, Mortar, and Grout," in 2000 Annual Book of ASTM Standards, V04.02, Concrete and Aggregates, American Society for Testing and Materials, pp. 652-657.

22. Cabrera,J.G., Woolley,G.R., and Hassan,K.E., (1997) "The Use of Fly Ash to Improve The Chloride Resistance of Cement Mortars", Waste Materials in Construction: Putting Theory into Practice, pp. 387-400.

23. Statistics provided by the national ready mixed concrete association, Silver Spring, MD. Ref. Cited in: "High-Performance Construction Materials and Systems," Technical Report 93-5011, CERF, Washington D.C., 1993.

24. "Better Roads 1993 Bridge Inventory"(1993), Better Roads Magazine, V.63, No.11, November 1993, P. 14.

25. "America's Highways: accelerating the search for innovation"(1987), Special Report 202, Transportation Research Board, Washington, D.C.

26. “Concrete Durability: A multibillion-Dollar Opportunity”(1987), NMAB-437, National Materials Advisory Board, Washington, D.C.

27. Edwards, D.L., (2000) "HPC on Bridges: The Florida Experience," Concrete International, V.22, February 2000. pp. 63-65.

28. Freeman, R.B., (1999) "Final Report on The Physical and Mechanical Properties of High-Performance Concrete Produced in Montana," Department of Civil Engineering, Montana State University-Bozeman. 
29. Goodspeed. C.H.; Vanikar.s; and Cook. R., (1996) "High-performance concrete defined for highway Structures," Concrete International, V.18, No.2, February 1996, pp. 62-67.

30. Larsen, T.J., Armaghani, J.M., (1987) “Quality concrete with Fly Ash," Paper, Florida Department of Transportation State Materials Office.

31. Larsen, T.J., (1995) "Use of Fly Ash in Structural Concrete," paper, Florida Department of Transportation State Materials Office, April 1995.

32. Mather, B., "Concrete in Transportation: Desired performance and Specifications," TRB No.1382 Material and Construction.

33. Mehta P. K., and Monteiro, J. M., (1993) “Concrete: Structure, Properties, and Materials," $2^{\text {nd }}$. Ed., Prentice-Hall, Inc., Englewood Cliffs.

34. Michael W.Beacham,M.W., (1999) "HPC Bridge Deck in Nebraska," Concrete International, pp. 66-68.

35. Moore,J.A.,(1999)."High-performance Concrete for Bridge Decks," Concrete international, V21, No.2, February, 1999, pp. 58-58.

36. Naik,T.R., Singh,S.S., and Hassain,M.M., (1994) "Permeability of Concrete Containing Large Amount of Fly Ash," Cement and Concrete Research, Vol.24, No.5, pp. 913-922.

37. Ozyildrim, C., (1999) "HPC Bridge Decks in Virginia," Concrete International, V21, No.2, February,1999, pp. 59-60.

38. Ozyildirim, C., (1994) "Laboratory Investigation of Low-permeability Concretes Containing Slag and Silica Fume," ACI Materials Journal, V.91, No.2,MarchApril 1994. Pp. 197-203.

39. Ozyildirim, C., and Halstead, W.J., (1989) " Use of Supplemental Cementitious Materials for Optimum Resistance of Concrete to Chloride Penetration," VTRC Report No. 89-R20, Charlottesville, VA.

40. Ozyildirim, C., and Halstead,W.J., (1988) “ Resistance to Chloride Ion Penetration of Concretes Containing Fly Ash, Silica Fume, or Slag," Permeability of Concrete, SP-108, American Concrete Institute, Detroit, pp. 35-61.

41. Ralls, M. L., (1999) " Texas HPC Bridge Decks", Concrete international, V21, No.2, February 1999, pp. 63-65. 
42. Russell, H. G., (1999). “ACI Defines High-performance Concrete," Concrete international, V21, No.2, February 1999, pp. 56-57.

43. Streeter, D. A., (1996) “Developing a High-Performance Concrete Mix for New York State Bridge Decks." Transportation Research Record 1532, Transportation Research Board, pp. 60-65.

44. Streeter, D. A., (1996) “ Field Experiences Using High-Performance Concrete on New York State Transportation Structures," Transportation Research Board $79^{\text {th }}$ Annual Meeting, January 9-13, 2000. Washington, D.C.

45. Waszczuk, C. M., and Juliano, M. L., (1999) "Application of HPC in a New Hampshire Bridge," Concrete International, pp. 61-62.

46. Zia, P., Ahmad. S.H., and Leming, M.L., (1996) "high-performance Concretes: a State-of-the-Art Report (1989-1994)," Federal Highway Administration, McLean, Virginia, $250 \mathrm{PP}$. 


\section{Appendix A: Compressive Strength Test Results}

Table A.1 Mix F1 Compressive Strength (Units: psi)

\begin{tabular}{|c|c|c|c|c|c|}
\hline \multirow{2}{*}{$\begin{array}{c}\text { Curing Time } \\
\text { (Days) }\end{array}$} & \multicolumn{3}{|c|}{ Compressive Strength } & \multirow{2}{*}{ Average } & \multirow{2}{*}{ Variation } \\
\cline { 2 - 4 } & Specimen 1 & Specimen 2 & Specimen 3 & & \\
\hline 1 & 3742 & 3662 & 3503 & 3636 & 122 \\
\hline 3 & 5135 & 5255 & 5175 & 5188 & 61 \\
\hline 7 & 6688 & 6449 & 6449 & 6529 & 138 \\
\hline 14 & 7962 & 7484 & 7126 & 7524 & 419 \\
\hline 28 & 8678 & 8376 & 8439 & 8498 & 160 \\
\hline 56 & 9156 & 8758 & 9514 & 9143 & 378 \\
\hline 90 & 9621 & 9477 & 9789 & 9629 & 156 \\
\hline
\end{tabular}

Table A.2 Mix F2 Compressive Strength (Units: psi)

\begin{tabular}{|c|c|c|c|c|c|}
\hline \multirow{2}{*}{$\begin{array}{c}\text { Curing Time } \\
\text { (Days) }\end{array}$} & \multicolumn{3}{|c|}{ Compressive Strength } & \multirow{2}{*}{ Average } & \multirow{2}{*}{ Variation } \\
\cline { 2 - 4 } & Specimen 1 & Specimen 2 & Specimen 3 & & \\
\hline 1 & 3304 & 3384 & N/A & 3344 & 56 \\
\hline 3 & 4936 & 5135 & 5135 & 5069 & 115 \\
\hline 7 & 5653 & 5772 & 6290 & 5905 & 339 \\
\hline 14 & 6648 & 6887 & 6489 & 6675 & 200 \\
\hline 28 & 8201 & 8201 & 7803 & 8068 & 230 \\
\hline 56 & 8997 & 9236 & 8041 & 8758 & 632 \\
\hline 90 & 9554 & 9315 & 9952 & 9607 & 322 \\
\hline
\end{tabular}

Table A.3 Mix F3 Compressive Strength (Units: psi)

\begin{tabular}{|c|c|c|c|c|c|}
\hline \multirow{2}{*}{$\begin{array}{c}\text { Curing Time } \\
\text { (Days) }\end{array}$} & \multicolumn{3}{|c|}{ Compressive Strength } & \multirow{2}{*}{ Average } & \multirow{2}{*}{ Variation } \\
\cline { 2 - 4 } & Specimen 1 & Specimen 2 & Specimen 3 & & \\
\hline 1 & 3662 & 3941 & 2667 & 3424 & 670 \\
\hline 3 & 5454 & 5573 & 5215 & 5414 & 182 \\
\hline 7 & 6648 & 6409 & 6210 & 6423 & 219 \\
\hline 14 & 7205 & 7086 & 7524 & 7272 & 226 \\
\hline 28 & 7564 & 7842 & 7803 & 7736 & 151 \\
\hline 56 & 8360 & 8479 & 8519 & 8453 & 83 \\
\hline 90 & 9475 & 9116 & 8997 & 9196 & 249 \\
\hline
\end{tabular}


Table A.4 Mix S1 Compressive Strength (Units: psi)

\begin{tabular}{|c|c|c|c|c|c|}
\hline \multirow{2}{*}{$\begin{array}{c}\text { Curing Time } \\
\text { (Days) }\end{array}$} & \multicolumn{3}{|c|}{ Compressive Strength } & \multirow{2}{*}{ Average } & \multirow{2}{*}{ Variation } \\
\cline { 2 - 4 } & Specimen 1 & Specimen 2 & Specimen 3 & & \\
\hline 1 & 2747 & 2747 & 2906 & 2800 & 92 \\
\hline 3 & 4538 & 4618 & 4697 & 4618 & 80 \\
\hline 7 & 6369 & 6568 & 6927 & 6622 & 282 \\
\hline 14 & 7365 & 7301 & 8201 & 7622 & 502 \\
\hline 28 & 8798 & 9475 & 9355 & 9209 & 361 \\
\hline 56 & 9891 & 9981 & N/A & 9936 & 64 \\
\hline 90 & 11306 & 11027 & N/A & 11166 & 197 \\
\hline
\end{tabular}

Table A.5 Mix S2 Compressive Strength (Units: psi)

\begin{tabular}{|c|c|c|c|c|c|}
\hline \multirow{2}{*}{$\begin{array}{c}\text { Curing Time } \\
\text { (Days) }\end{array}$} & \multicolumn{3}{|c|}{ Compressive Strength } & \multirow{2}{*}{ Average } & \multirow{2}{*}{ Variation } \\
\cline { 2 - 4 } & Specimen 1 & Specimen 2 & Specimen 3 & & \\
\hline 1 & 2389 & 2189 & N/A & 2289 & 141 \\
\hline 3 & 4180 & 4260 & 4260 & 4233 & 46 \\
\hline 7 & 6091 & 5971 & 6369 & 6144 & 204 \\
\hline 14 & 7285 & 7126 & 7086 & 7166 & 105 \\
\hline 28 & 8002 & 9076 & 9116 & 8731 & 632 \\
\hline 56 & 8917 & 8917 & 9514 & 9116 & 345 \\
\hline 90 & 9634 & 9634 & 9674 & 9647 & 23 \\
\hline
\end{tabular}

Table A.6 Mix S3 Compressive Strength (Units: psi)

\begin{tabular}{|c|c|c|c|c|c|}
\hline \multirow{2}{*}{$\begin{array}{c}\text { Curing Time } \\
\text { (Days) }\end{array}$} & \multicolumn{3}{|c|}{ Compressive Strength } & \multirow{2}{*}{ Average } & \multirow{2}{*}{ Variation } \\
\cline { 2 - 4 } & Specimen 1 & Specimen 2 & Specimen 3 & & 141 \\
\hline 1 & 2468 & 2269 & & 2369 & 322 \\
\hline 3 & 5175 & 5175 & 4618 & 4989 & 161 \\
\hline 7 & 6250 & 6449 & 6568 & 6423 & 359 \\
\hline 14 & 8280 & 7564 & 7882 & 7909 & 498 \\
\hline 28 & 8599 & 8121 & 9116 & 8612 & 383 \\
\hline 56 & 9037 & 9793 & 9315 & 9382 & 287 \\
\hline 90 & 9793 & 10350 & 9952 & 10032 & 2 \\
\hline
\end{tabular}




\section{Appendix B: Shrinkage Test Results}

Table B.1 Mix F1 Shrinkage at Different Ages (Units: $\mu \varepsilon$ )

\begin{tabular}{|c|c|c|c|c|c|}
\hline \multirow{2}{*}{$\begin{array}{c}\text { Time } \\
\text { (Days) }\end{array}$} & \multicolumn{3}{|c|}{ Shrinkage } & \multirow{2}{*}{ Average } & \multirow{2}{*}{ Variation } \\
\cline { 2 - 4 } & Spec 1 & Spec 2 & Spec 3 & & \\
\hline 0 & 0.0 & 0.0 & 0.0 & 0.0 & 0.0 \\
\hline 4 & 184.0 & 152.0 & 120.0 & 152.0 & 26.1 \\
\hline 7 & 256.0 & 224.0 & 216.0 & 232.0 & 17.3 \\
\hline 14 & 264.0 & 296.0 & 296.0 & 285.3 & 15.1 \\
\hline 21 & 360.0 & 336.0 & 312.0 & 336.0 & 19.6 \\
\hline 28 & 336.0 & 328.0 & 328.0 & 330.7 & 3.8 \\
\hline 35 & 304.0 & 264.0 & 248.0 & 272.0 & 23.6 \\
\hline 42 & 336.0 & 296.0 & 288.0 & 306.7 & 21.0 \\
\hline 49 & 328.0 & 296.0 & 280.0 & 301.3 & 20.0 \\
\hline 56 & 336.0 & 312.0 & 296.0 & 314.7 & 16.4 \\
\hline
\end{tabular}

Table B.2 Mix F2 Shrinkage at Different Ages (Units: $\mu \varepsilon$ )

\begin{tabular}{|c|c|c|c|c|c|}
\hline \multirow{2}{*}{$\begin{array}{c}\text { Time } \\
\text { (Days) }\end{array}$} & \multicolumn{3}{|c|}{ Shrinkage } & \multirow{2}{*}{ Average } & \multirow{2}{*}{ Variation } \\
\cline { 2 - 4 } & Spec 1 & Spec 2 & Spec 3 & & \\
\hline 0 & 0.0 & 0.0 & 0.0 & 0.0 & 0.0 \\
\hline 4 & 136.0 & 160.0 & 200.0 & 165.3 & 26.4 \\
\hline 7 & 224.0 & 256.0 & 272.0 & 250.7 & 20.0 \\
\hline 14 & 320.0 & 352.0 & 344.0 & 338.7 & 13.6 \\
\hline 21 & 312.0 & 304.0 & 308.0 & 308.0 & 3.3 \\
\hline 28 & 344.0 & 336.0 & 368.0 & 349.3 & 13.6 \\
\hline 35 & 360.0 & 352.0 & 368.0 & 360.0 & 6.5 \\
\hline 42 & 376.0 & 392.0 & 384.0 & 384.0 & 6.5 \\
\hline 49 & 328.0 & 344.0 & 352.0 & 341.3 & 10.0 \\
\hline 56 & 336.0 & 328.0 & 360.0 & 341.3 & 13.6 \\
\hline
\end{tabular}

Table B.3 Mix F3 Shrinkage at Different Ages (Units: $\mu \varepsilon$ )

\begin{tabular}{|c|c|c|c|c|c|}
\hline \multirow{2}{*}{$\begin{array}{c}\text { Time } \\
\text { (Days) }\end{array}$} & \multicolumn{3}{|c|}{ Shrinkage } & \multirow{2}{*}{ Average } & \multirow{2}{*}{ Variation } \\
\cline { 2 - 4 } & Spec 1 & Spec 2 & Spec 3 & & \\
\hline 0 & 0.0 & 0.0 & 0.0 & 0.0 & 0.0 \\
\hline 4 & 216.0 & 176.0 & 192.0 & 194.7 & 16.4 \\
\hline 7 & 272.0 & 320.0 & 272.0 & 288.0 & 22.6 \\
\hline 14 & 312.0 & 368.0 & 352.0 & 344.0 & 23.6 \\
\hline 21 & 336.0 & 392.0 & 368.0 & 365.3 & 22.9 \\
\hline 28 & 304.0 & 384.0 & 352.0 & 346.7 & 32.9 \\
\hline 35 & 344.0 & 392.0 & 384.0 & 373.3 & 21.0 \\
\hline 42 & 344.0 & 448.0 & 440.0 & 410.7 & 47.3 \\
\hline 49 & 368.0 & 416.0 & 400.0 & 394.7 & 20.0 \\
\hline 56 & 328.0 & 400.0 & 376.0 & 368.0 & 29.9 \\
\hline
\end{tabular}


Table B.4 Mix S1 Shrinkage at Different Ages (Units: $\mu \varepsilon$ )

\begin{tabular}{|c|c|c|c|c|c|}
\hline \multirow{2}{*}{$\begin{array}{c}\text { Time } \\
\text { (Days) }\end{array}$} & \multicolumn{3}{|c|}{ Shrinkage } & \multirow{2}{*}{ Average } & \multirow{2}{*}{ Variation } \\
\cline { 2 - 4 } & Spec 1 & Spec 2 & Spec 3 & & \\
\hline 0 & 0.0 & 0.0 & 0.0 & 0.0 & 0.0 \\
\hline 4 & 192.0 & 80.0 & 232.0 & 212.0 & 28.3 \\
\hline 7 & 248.0 & 88.0 & 296.0 & 272.0 & 33.9 \\
\hline 14 & 288.0 & -64.0 & 304.0 & 296.0 & 11.3 \\
\hline 21 & 344.0 & 192.0 & 368.0 & 356.0 & 17.0 \\
\hline 28 & 352.0 & 224.0 & 384.0 & 368.0 & 22.6 \\
\hline 35 & 384.0 & 96.0 & 400.0 & 392.0 & 11.3 \\
\hline 42 & 344.0 & 120.0 & 368.0 & 356.0 & 17.0 \\
\hline 49 & 352.0 & 184.0 & 368.0 & 360.0 & 11.3 \\
\hline 56 & 328.0 & 168.0 & 344.0 & 336.0 & 11.3 \\
\hline
\end{tabular}

Table B.5 Mix S2 Shrinkage at Different Ages (Units: $\mu \varepsilon$ )

\begin{tabular}{|c|c|c|c|c|c|}
\hline \multirow{2}{*}{$\begin{array}{c}\text { Time } \\
\text { (Days) }\end{array}$} & \multicolumn{3}{|c|}{ Shrinkage } & \multirow{2}{*}{ Average } & \multirow{2}{*}{ Variation } \\
\cline { 2 - 4 } & Spec 1 & Spec 2 & Spec 3 & & \\
\hline 0 & 0.0 & 0.0 & 0.0 & 0.0 & 0.0 \\
\hline 4 & 150.0 & 236.0 & 296.0 & 172.0 & 66.0 \\
\hline 7 & 160.0 & 272.0 & 312.0 & 248.0 & 64.3 \\
\hline 14 & 240.0 & 312.0 & 336.0 & 296.0 & 40.8 \\
\hline 21 & 240.0 & 312.0 & 352.0 & 301.3 & 46.3 \\
\hline 28 & 264.0 & 320.0 & 360.0 & 314.7 & 39.4 \\
\hline 35 & 320.0 & 392.0 & 416.0 & 376.0 & 40.8 \\
\hline 42 & 296.0 & 344.0 & 376.0 & 338.7 & 32.9 \\
\hline 49 & 280.0 & 320.0 & 344.0 & 314.7 & 26.4 \\
\hline 56 & 248.0 & 304.0 & 336.0 & 296.0 & 36.4 \\
\hline
\end{tabular}

Table B.6 Mix S3 Shrinkage at Different Ages (Units: $\mu \varepsilon$ )

\begin{tabular}{|c|c|c|c|c|c|}
\hline \multirow{2}{*}{$\begin{array}{c}\text { Time } \\
\text { (Days) }\end{array}$} & \multicolumn{3}{|c|}{ Shrinkage } & \multirow{2}{*}{ Average } & \multirow{2}{*}{ Variation } \\
\cline { 2 - 4 } & Spec 1 & Spec 2 & Spec 3 & & \\
\hline 0 & 0.0 & 0.0 & 0.0 & 0.0 & 0.0 \\
\hline 4 & 168.0 & 128.0 & 136.0 & 144.0 & 17.3 \\
\hline 7 & 224.0 & 192.0 & 176.0 & 197.3 & 20.0 \\
\hline 14 & 352.0 & 328.0 & 296.0 & 325.3 & 22.9 \\
\hline 21 & 352.0 & 336.0 & 328.0 & 338.7 & 10.0 \\
\hline 28 & 352.0 & 328.0 & 288.0 & 322.7 & 26.4 \\
\hline 35 & 392.0 & 368.0 & 320.0 & 360.0 & 29.9 \\
\hline 42 & 368.0 & 344.0 & 304.0 & 338.7 & 26.4 \\
\hline 49 & 360.0 & 296.0 & 288.0 & 314.7 & 32.2 \\
\hline 56 & 352.0 & 328.0 & 280.0 & 320.0 & 29.9 \\
\hline
\end{tabular}




\section{Appendix C: Rapid Freeze/Thaw Test Results}

Table C.1 Mix F1 Rapid Freeze/Thaw Test Results

\begin{tabular}{|c|c|c|c|c|c|c|c|c|}
\hline \multirow{2}{*}{$\begin{array}{c}\text { Freezing } \\
\text { /Thawing } \\
\text { Cycles }\end{array}$} & \multicolumn{2}{|c|}{$\begin{array}{c}\text { Weight } \\
\text { (lbs) }\end{array}$} & \multicolumn{2}{c|}{$\begin{array}{c}\text { Length } \\
\text { (inch) }\end{array}$} & \multicolumn{2}{c|}{$\begin{array}{c}\text { Cross Section } \\
\left.\text { (inch }^{2}\right)\end{array}$} & \multicolumn{2}{c|}{$\begin{array}{c}\text { Frequency } \\
\text { (Hz) }\end{array}$} \\
\hline & 1 & 2 & 1 & 2 & 1 & 2 & 1 & 2 \\
\hline Initial & 16.31 & 16.63 & 16.00 & 16.00 & $3 \times 4$ & $3 \times 4$ & 1786 & $\begin{array}{c}1803- \\
\end{array}$ \\
\hline 50 & 16.31 & 16.63 & 16.00 & 16.00 & $3 \times 4$ & $3 \times 4$ & 1772 & 1797 \\
\hline 100 & 16.33 & 16.63 & 16.00 & 15.97 & $2.97 \times 4$ & $3 \times 4$ & 1780 & 1792 \\
\hline 150 & 16.33 & 16.64 & 15.97 & 16.00 & $3.03 \times 4$ & $3.03 \times 4$ & 1786 & 1813 \\
\hline 200 & 16.31 & 16.62 & 16.00 & 16.00 & $3 \times 4$ & $3.03 \times 4$ & 1794 & 1803 \\
\hline 250 & 16.32 & 16.62 & 15.97 & 16.00 & $2.97 \times 4$ & $3.06 \times 4$ & 1799 & 1827 \\
\hline 300 & 16.29 & 16.60 & 15.94 & 15.93 & $3 \times 4$ & $3 \times 4$ & 1792 & 1819 \\
\hline 350 & 16.24 & 16.59 & 16.00 & 15.97 & $3 \times 4$ & $3 \times 4$ & 1787 & 1818 \\
\hline
\end{tabular}

Note: First 50 -cycle test starts at 14 days after initial reading

Table C.2 Mix F2 Rapid Freeze/Thaw Test Results

\begin{tabular}{|c|c|c|c|c|c|c|c|c|}
\hline \multirow{2}{*}{$\begin{array}{c}\text { Freezing } \\
\text { /Thawing } \\
\text { Cycles }\end{array}$} & \multicolumn{2}{|c|}{$\begin{array}{c}\text { Weight } \\
\text { (Ibs) }\end{array}$} & \multicolumn{2}{c|}{$\begin{array}{c}\text { Length } \\
\text { (inch) }\end{array}$} & \multicolumn{2}{c|}{$\begin{array}{c}\text { Cross Section } \\
\left(\text { in }^{2}\right)\end{array}$} & \multicolumn{2}{c|}{$\begin{array}{c}\text { Frequency } \\
\text { (Hz) }\end{array}$} \\
\cline { 2 - 9 } & 1 & 2 & 1 & 2 & 1 & 2 & 1 & 2 \\
\hline Initial & 17.04 & 16.91 & 16.00 & 16.00 & $3 \times 4$ & $3 \times 4$ & 1810 & 1816 \\
\hline 50 & 16.89 & 17.02 & 16.00 & 16.03 & $3 \times 4$ & $3 \times 4$ & 1812 & 1818 \\
\hline 100 & 16.88 & 17.00 & 16.00 & 16.03 & $3 \times 4$ & $3 \times 4$ & 1823 & 1827 \\
\hline 150 & 16.91 & 17.00 & 16.00 & 16.00 & $3.03 \times 4$ & $3 \times 4$ & 1820 & 1819 \\
\hline 200 & 16.89 & 16.96 & 16.00 & 15.93 & $3.03 \times 4$ & $3 \times 4$ & 1820 & 1835 \\
\hline 250 & 16.86 & 16.89 & 16 & 16 & $3 \times 4$ & $3 \times 4$ & 1825 & 1830 \\
\hline 300 & 16.85 & 16.88 & 16 & 16 & $3.03 \times 3.97$ & $2.97 \times 4$ & 1828 & 1838 \\
\hline
\end{tabular}

Note: First 50 -cycle test starts at 14 days after initial reading

Table C.3 Mix F3 Rapid Freeze/Thaw Test Results

\begin{tabular}{|c|c|c|c|c|c|c|c|c|}
\hline \multirow{2}{*}{$\begin{array}{c}\text { Freezing } \\
\text { /Thawing } \\
\text { Cycles }\end{array}$} & \multicolumn{2}{|c|}{$\begin{array}{c}\text { Weight } \\
\text { (lbs) }\end{array}$} & \multicolumn{2}{c|}{$\begin{array}{c}\text { Length } \\
\text { (inch) }\end{array}$} & \multicolumn{2}{c|}{$\begin{array}{c}\text { Cross Section } \\
\left(\text { inch }^{2}\right)\end{array}$} & \multicolumn{2}{c|}{$\begin{array}{c}\text { Frequency } \\
\text { (Hz) }\end{array}$} \\
\cline { 2 - 9 } & 1 & 2 & 1 & 2 & 1 & 2 & 1 & 2 \\
\hline Initial & 16.47 & 16.99 & 16.00 & 16.00 & $3 \times 4$ & $3 \times 4$ & 1780 & 1820 \\
\hline 50 & N/A & 16.99 & N/A & 15.97 & N/A & $3 \times 4$ & N/A & 1807 \\
\hline 100 & 16.49 & 16.98 & 16.06 & 16.00 & $3.03 \times 4$ & $3 \times 4$ & 1760 & 1819 \\
\hline 150 & 16.48 & 17.00 & 16.06 & 16.00 & $3.03 \times 4$ & $3 \times 4.03$ & 1771 & 1825 \\
\hline 200 & 16.48 & 16.98 & 16.03 & 16.00 & $3.03 \times 4$ & $3 \times 4$ & 1769 & 1825 \\
\hline 250 & 16.48 & 16.96 & 16.00 & 16.00 & $3 \times 4$ & $3 \times 4$ & 1773 & 1832 \\
\hline 300 & 16.45 & 16.93 & 16.03 & 15.97 & $3 \times 4$ & $3.06 \times 4$ & 1779 & 1843 \\
\hline
\end{tabular}

Note: First 50 -cycle test starts at 14 days after initial reading 
Table C.4 Mix S1 Rapid Freeze/Thaw Test Results

\begin{tabular}{|c|c|c|c|c|c|c|c|c|}
\hline \multirow{2}{*}{$\begin{array}{c}\text { Freezing } \\
\text { /Thawing } \\
\text { Cycles }\end{array}$} & \multicolumn{2}{|c|}{$\begin{array}{c}\text { Weight } \\
\text { (lbs) }\end{array}$} & \multicolumn{2}{c|}{$\begin{array}{c}\text { Length } \\
\text { (inch) }\end{array}$} & \multicolumn{2}{c|}{$\begin{array}{c}\text { Cross Section } \\
\text { (inch }^{2} \text { ) }\end{array}$} & \multicolumn{2}{c|}{$\begin{array}{c}\text { Frequency } \\
\text { (Hz) }\end{array}$} \\
\cline { 2 - 9 } & 1 & 2 & 1 & 2 & 1 & 2 & 1 & 2 \\
\hline Initial & 16.92 & 17.07 & 16.00 & 16.00 & $3 \times 4$ & $3 \times 4$ & 1814 & 1837 \\
\hline 50 & 16.90 & 17.06 & 16.00 & 16.00 & $3 \times 4$ & $3.06 \times 4$ & 1815 & 1839 \\
\hline 100 & 16.90 & 17.06 & 15.97 & 16.00 & $3.03 \times 4$ & $3.06 \times 4$ & 1797 & 1830 \\
\hline 150 & 16.92 & 17.07 & 16.00 & 16.00 & $3.06 \times 4$ & $3.06 \times 4$ & 1818 & 1845 \\
\hline 200 & 16.86 & 17.04 & 16.00 & 16.00 & $3.03 \times 4$ & $3.06 \times 4$ & 1822 & 1846 \\
\hline 250 & 16.84 & 17.03 & 16.00 & 16.00 & $3.03 \times 4$ & $3.06 \times 4.03$ & 1816 & 1853 \\
\hline 300 & N/A & N/A & N/A & N/A & N/A & N/A & N/A & N/A \\
\hline
\end{tabular}

Note: First 50-cycle test starts at 14 days after initial reading

Table C.5 Mix S2 Rapid Freeze/Thaw Test Results

\begin{tabular}{|c|c|c|c|c|c|c|c|c|}
\hline \multirow{2}{*}{$\begin{array}{c}\text { Freezing } \\
\text { Thawing } \\
\text { Cycles }\end{array}$} & \multicolumn{2}{|c|}{$\begin{array}{c}\text { Weight } \\
\text { (lbs) }\end{array}$} & \multicolumn{2}{c|}{$\begin{array}{c}\text { Length } \\
\text { (inch) }\end{array}$} & \multicolumn{2}{c|}{$\begin{array}{c}\text { Cross Section } \\
\text { (inch }^{2} \text { ) }\end{array}$} & \multicolumn{2}{c|}{$\begin{array}{c}\text { Frequency } \\
\text { (Hz) }\end{array}$} \\
\cline { 2 - 9 } & 1 & 2 & 1 & 2 & 1 & 2 & 1 & 2 \\
\hline Initial & 16.68 & 16.43 & 16.00 & 16.00 & $3 \times 4$ & $3 \times 4$ & 1780 & 1792 \\
\hline 50 & 16.68 & 16.44 & 15.97 & 15.97 & $3 \times 4.03$ & $3.03 \times 4$ & 1784 & 1797 \\
\hline 100 & 16.68 & 16.44 & 16.00 & 16.00 & $3.03 \times 4.03$ & $3.03 \times 4$ & 1773 & 1779 \\
\hline 150 & 16.69 & 16.45 & 16.00 & 16.00 & $3.03 \times 4$ & $3 \times 4$ & 1788 & 1794 \\
\hline 200 & 16.69 & 16.42 & 16.00 & 16.00 & $3 \times 4$ & $3.06 \times 4$ & 1789 & 1801 \\
\hline 250 & 16.65 & 16.37 & 16.00 & 16.00 & $3 \times 4$ & $3 \times 4$ & 1784 & 1801 \\
\hline 300 & 16.65 & 16.35 & 16.00 & 16.00 & $3 \times 4.03$ & $3 \times 4$ & 1795 & 1806 \\
\hline
\end{tabular}

Note: First 50-cycle test starts at 14 days after initial reading

Table C.6 Mix S3 Rapid Freeze/Thaw Test Results

\begin{tabular}{|c|c|c|c|c|c|c|c|c|}
\hline $\begin{array}{c}\text { Freezing } \\
\text { /Thawing } \\
\text { Cycles }\end{array}$ & \multicolumn{2}{|c|}{$\begin{array}{c}\text { Weight } \\
\text { (lbs) }\end{array}$} & \multicolumn{2}{c|}{$\begin{array}{c}\text { Length } \\
\text { (inch) }\end{array}$} & \multicolumn{2}{c|}{$\begin{array}{c}\text { Cross Section } \\
\text { (inch }^{2} \text { ) }\end{array}$} & \multicolumn{2}{c|}{$\begin{array}{c}\text { Frequency } \\
\text { (Hz) }\end{array}$} \\
\cline { 2 - 9 } & 1 & 2 & 1 & 2 & 1 & 2 & 1 & 2 \\
\hline Initial & 16.54 & 16.48 & 16.00 & 16.00 & $3 \times 4$ & $3 \times 4$ & 1810 & 1795 \\
\hline 50 & 16.49 & 16.53 & 16.00 & 16.00 & $3 \times 4$ & $3 \times 4$ & 1779 & 1790 \\
\hline 100 & 16.51 & 16.53 & 16.00 & 16.00 & $3 \times 4$ & $3.03 \times 4$ & 1799 & 1805 \\
\hline 150 & 16.52 & 16.56 & 16.00 & 16.00 & $3.06 \times 4$ & $3.03 \times 4$ & 1789 & 1786 \\
\hline 200 & 16.49 & 16.53 & 16.00 & 16.00 & $3 \times 4$ & $3 \times 4$ & 1797 & 1806 \\
\hline 250 & 16.49 & 16.49 & 16.00 & 16.00 & $3.06 \times 4$ & $3 \times 4$ & 1798 & 1816 \\
\hline 300 & 16.44 & 16.50 & 16.00 & 16.00 & $3.03 \times 4$ & $3 \times 4$ & 1786 & 1814 \\
\hline
\end{tabular}

Note: First 50-cycle test starts at 14 days after initial reading 


\section{Appendix D: 42-Day RCPT Test Results}

Table D.1 Mix F1 42-Day Permeability Test Results

\begin{tabular}{|c|c|c|c|c|}
\hline & \multicolumn{2}{|c|}{ Specimen 1 } & \multicolumn{2}{c|}{ Specimen 2 } \\
\hline Time & Current & Charge & Current & Charge \\
\hline (Min.) & (AMP) & (Coulombs) & (AMP) & (Coulombs) \\
\hline 0 & 0 & 0 & 0 & 0 \\
\hline 30 & 0.032 & 63 & 0.030 & 56 \\
\hline 60 & 0.033 & 123 & 0.031 & 113 \\
\hline 90 & 0.034 & 185 & 0.032 & 172 \\
\hline 120 & 0.035 & 249 & 0.033 & 233 \\
\hline 150 & 0.036 & 314 & 0.033 & 294 \\
\hline 180 & 0.036 & 381 & 0.034 & 357 \\
\hline 210 & 0.038 & 449 & 0.034 & 421 \\
\hline 240 & 0.038 & 518 & 0.035 & 485 \\
\hline 270 & 0.039 & 588 & 0.036 & 551 \\
\hline 300 & 0.039 & 659 & 0.037 & 618 \\
\hline 330 & 0.040 & 730 & 0.037 & 686 \\
\hline 360 & 0.040 & 803 & 0.038 & 755 \\
\hline
\end{tabular}

Table D.2 Mix F2 42-Day Permeability Test Results

\begin{tabular}{|c|c|c|c|c|}
\hline & \multicolumn{2}{|c|}{ Specimen 1 } & \multicolumn{2}{c|}{ Specimen 2 } \\
\hline Time & Current & Charge & Current & Charge \\
\hline (Min.) & (AMP) & (Coulombs) & (AMP) & (Coulombs) \\
\hline 0 & 0 & 0 & 0 & 0 \\
\hline 30 & 0.038 & 68 & 0.036 & 64 \\
\hline 60 & 0.039 & 140 & 0.037 & 131 \\
\hline 90 & 0.041 & 214 & 0.038 & 200 \\
\hline 120 & 0.043 & 292 & 0.038 & 271 \\
\hline 150 & 0.045 & 372 & 0.039 & 343 \\
\hline 180 & 0.046 & 456 & 0.040 & 417 \\
\hline 210 & 0.048 & 542 & 0.041 & 491 \\
\hline 240 & 0.050 & 630 & 0.041 & 567 \\
\hline 270 & 0.051 & 721 & 0.043 & 645 \\
\hline 300 & 0.052 & 814 & 0.043 & 723 \\
\hline 330 & 0.053 & 910 & 0.044 & 803 \\
\hline 360 & 0.056 & 1008 & 0.046 & 885 \\
\hline
\end{tabular}


Table D.3 Mix F3 42-Day Permeability Test Results

\begin{tabular}{|c|c|c|c|c|}
\hline & \multicolumn{2}{|c|}{ Specimen 1 } & \multicolumn{2}{c|}{ Specimen 2 } \\
\hline Time & Current & Charge & Current & Charge \\
\hline (Min.) & (AMP) & (Coulombs) & (AMP) & (Coulombs) \\
\hline 0 & 0 & 0 & 0 & 0 \\
\hline 30 & 0.049 & 86 & 0.053 & 93 \\
\hline 60 & 0.051 & 177 & 0.056 & 193 \\
\hline 90 & 0.054 & 273 & 0.059 & 297 \\
\hline 120 & 0.056 & 372 & 0.06 & 404 \\
\hline 150 & 0.058 & 475 & 0.063 & 516 \\
\hline 180 & 0.059 & 581 & 0.064 & 630 \\
\hline 210 & 0.061 & 689 & 0.065 & 747 \\
\hline 240 & 0.061 & 799 & 0.066 & 865 \\
\hline 270 & 0.063 & 912 & 0.069 & 987 \\
\hline 300 & 0.063 & 1025 & 0.069 & 1110 \\
\hline 330 & 0.064 & 1140 & 0.07 & 1236 \\
\hline 360 & 0.065 & 1256 & 0.071 & 1363 \\
\hline
\end{tabular}

Table D.4 Mix S1 42-Day Permeability Test Results

\begin{tabular}{|c|c|c|c|c|}
\hline & \multicolumn{2}{|c|}{ Specimen 1 } & \multicolumn{2}{c|}{ Specimen 2 } \\
\hline Time & Current & Charge & Current & Charge \\
\hline (Min.) & (AMP) & (Coulombs) & (AMP) & (Coulombs) \\
\hline 0 & 0 & 0 & 0 & 0 \\
\hline 30 & 0.029 & 53 & 0.039 & 70 \\
\hline 60 & 0.030 & 108 & 0.041 & 144 \\
\hline 90 & 0.030 & 164 & 0.042 & 219 \\
\hline 120 & 0.031 & 221 & 0.042 & 295 \\
\hline 150 & 0.031 & 279 & 0.042 & 371 \\
\hline 180 & 0.032 & 337 & 0.041 & 448 \\
\hline 210 & 0.031 & 395 & 0.041 & 524 \\
\hline 240 & 0.031 & 453 & 0.042 & 601 \\
\hline 270 & 0.032 & 510 & 0.042 & 677 \\
\hline 300 & 0.031 & 567 & 0.042 & 753 \\
\hline 330 & 0.031 & 624 & 0.042 & 830 \\
\hline 360 & 0.031 & 681 & 0.042 & 906 \\
\hline
\end{tabular}


Table D.5 Mix S2 42-Day Permeability Test Results

\begin{tabular}{|c|c|c|c|c|}
\hline & \multicolumn{2}{|c|}{ Specimen 1 } & \multicolumn{2}{c|}{ Specimen 2 } \\
\hline Time & Current & Charge & Current & Charge \\
\hline (Min.) & (AMP) & (Coulombs) & (AMP) & (Coulombs) \\
\hline 0 & 0 & 0 & 0 & 0 \\
\hline 30 & 0.031 & 55 & 0.026 & 48 \\
\hline 60 & 0.031 & 112 & 0.027 & 98 \\
\hline 90 & 0.031 & 169 & 0.027 & 148 \\
\hline 120 & 0.031 & 226 & 0.027 & 198 \\
\hline 150 & 0.031 & 284 & 0.027 & 249 \\
\hline 180 & 0.031 & 343 & 0.028 & 300 \\
\hline 210 & 0.032 & 402 & 0.027 & 350 \\
\hline 240 & 0.032 & 461 & 0.027 & 401 \\
\hline 270 & 0.033 & 520 & 0.027 & 451 \\
\hline 300 & 0.031 & 579 & 0.027 & 501 \\
\hline 330 & 0.032 & 638 & 0.027 & 551 \\
\hline 360 & 0.032 & 697 & 0.027 & 600 \\
\hline
\end{tabular}

Table D.6 Mix S3 42-Day Permeability Test Results

\begin{tabular}{|c|c|c|c|c|}
\hline & \multicolumn{2}{|c|}{ Specimen 1 } & \multicolumn{2}{c|}{ Specimen 2 } \\
\hline Time & Current & Charge & Current & Charge \\
\hline (Min.) & (AMP) & (Coulombs) & (AMP) & (Coulombs) \\
\hline 0 & 0 & 0 & 0 & 0 \\
\hline 30 & 0.044 & 79 & 0.034 & 61 \\
\hline 60 & 0.046 & 162 & 0.035 & 126 \\
\hline 90 & 0.048 & 248 & 0.036 & 192 \\
\hline 120 & 0.05 & 338 & 0.037 & 259 \\
\hline 150 & 0.051 & 430 & 0.037 & 327 \\
\hline 180 & 0.052 & 524 & 0.037 & 396 \\
\hline 210 & 0.053 & 621 & 0.038 & 465 \\
\hline 240 & 0.055 & 718 & 0.039 & 535 \\
\hline 270 & 0.055 & 818 & 0.038 & 606 \\
\hline 300 & 0.056 & 918 & 0.039 & 677 \\
\hline 330 & 0.056 & 1020 & 0.039 & 749 \\
\hline 360 & 0.057 & 1122 & 0.04 & 821 \\
\hline
\end{tabular}

